\title{
BANK-SPONSORED INVESTMENT MANAGEMENT SERVICES: CONSIDERATION OF THE REGULATORY PROBLEMS, AND SUGGESTED LEGISLATIVE AND STATUTORY INTERPRETIVE RESPONSES
}

\author{
MARTIN E. LYBECKER*
}

I. INTRODUCTION ............................................. 985

II. DESCRIPTION OF MAJOR BANK-SPONSORED INVESTMENT MANAGEMENT SERVICES ....................................... 988

A. Common Trust Funds ................................. 988

B. Commingled Managing Agency Accounts; Investment Adviser to Investment Company ............... 994

1. The Citibank Application, Congressional Hearings, and Litigation

2. The 1970 Bank Holding Company Act Amendments and Federal Reserve Board Regulation Y ............ 998

3. Statutory Interpretive Analysis ....................... 1001

C. Corporate Employee Benefit and Keogh Plan Trusts..... 1002

D. Mini-Accounts ........................................... 1008

E. Reflections ................................................ 1011

III. Comparative Regulation Under the Federal Securities AND BANKING LAWS .......................................... 1012

A. Information Disseminated About the Service............. 1012

B. Statutory and Other Implied Fiduciary Responsibilities... 1017

1. Professional Qualifications and

Financial Responsibility .......................... 1017

2. Compensation..................................... 1021

3. Suitability of Investments ......................... 1024

4. Conflicts of Interest ............................. 1025

C. Restrictions on Capital Structure and Investment Decisionmaking ............................. 1030

D. Private Rights of Action ............................... 1033

* Visiting Associate Professor of Law, Duke University (1977-78); Associate Professor of Law, State University of New York at Buffalo (on leave, 1977-78). B.B.A. 1967, J.D. 1970, University of Washington; LL.M. (in Taxation) 1971, New York University; LL.M. 1973, University of Pennsylvania. Member, Washington State and District of Columbia Bars. The author acknowledges receipt of a Summer Research Fellowship in Law and Social Policy during 1976 and 1977 from the Christopher Baldy Fund, State University of New York at Buffalo. 
IV. SUGGested LeGiSLATIVE AND STATUTORY INTERPRETIVE

RESPONSES ............................................ 1037

A. Glass-Steagall Act .................................. 1038

B. Federal Securities Laws and the ALI Federal

Securities Code Project ................................... 1040

1. Securities Act of 1933 .............................. 1041

2. Securities Exchange Act............................ 1042

a. Continuous Disclosure Provisions............... 1042

b. Broker-Dealer Regulatory Provisions ........... 1042

3. Investment Company Act ........................... 1042

4. Investment Advisers Act ............................. 1043

C. Allocation of Regulatory Responsibility and

Oversight Function ...................................... 1043

V. CONCLUSION .............................................. 1044

THE FOLLOWING CITATIONS WILL BE USED IN THIS ARTICLE:

Hearing on Common Trust Funds-Overlapping Responsibility and Conflict in Regulations Before a Subcomm. of the House Comm. on Government Operations, 88th Cong., 1st Sess. (1963) [hereinafter cited as Fascell 1963 Hearing];

Hearings on S. 2704 Before a Subcomm. of the Senate Comm. on Banking \& Currency, 89th Cong., 2d Sess. (1966) [hereinafter cited as S. 2704 Hearings];

ADVISORY COMMITTEe on INVESTMENT MANAGEMENT SERVICES FOR INDIVIDUAL INVEStors, Securities \& Exchange Comm'n, Small account Investment Management Services: Recommendations for Clearer Guidelines and Policies, Fed. SEC. L. ReP. (CCH) No. 465, pt. II (Feb. 1973) [hereinafter cited as ADVISORY COMMITTEE REPORT];

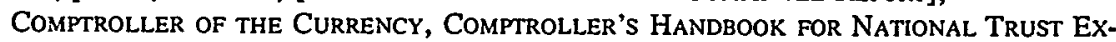
AMINERS (1977) [hereinafter cited as COMPTROLLER'S HANDBOOK];

COMPTROLleR OF THE CURRENCY, COMPTROLLER'S MANUAL FOR REPRESENTATIVES IN TRUSTS (1969) [hereinafter cited as COMPTROLLER'S EXAMINATION MANUAL];

R. Jennings \& H. MaRSh, JR., Securities Regulation (3d ed. 1972) [hereinafter cited as JENNINGS \& MARSH];

L. Loss, SeCurities Regulation (2d ed. 1961 \& Supp. 1969) [hereinafter cited as Loss];

North, The Investment Company Amendments Act of 1970, 46 NOTRE Dame LaW. 712 (1971) [hereinafter cited as North];

Rosenblat \& Lybecker, Some Thoughts on the Federal Securities Laws Regulating External Investment Management Arrangements and the ALI Federal Securities Code Project, $124 \mathrm{U}$. PA. L. REv. 587 (1976) [hereinafter cited as Rosenblat \& Lybecker];

Securities \& Exch. Comm'n, Initial Report on Bank Securities Activities (Jan. 3, 1977), FED. SEC. L. REP. (CCH) No. 676, pt. II (Jan. 12, 1977) [hereinafter cited as Initial SEC Bank Study Report];

Securities \& Exch. Comm'n, Second Report on Bank Securities Activities: Comparative Regulatory Framework Regarding Brokerage-Type Services (Feb. 3, 1977), FED. SEC. L. REP. (CCH) No. 680, pt. II (Feb. 9, 1977) [hereinafter cited as Second SEC Bank Study Report];

Securities \& Exch. Comm'n, Final Report on Bank Securities Activities (June 30, 1977), FED. SEC. L. REP. (CCH) No. 701, extra ed. (July 5, 1977) [hereinafter cited as Final SEC Bank Study Report]. 


\section{INTRODUCTION}

During the past two decades one of the most controversial subjects among those interested in the regulation of financial institutions as institutional investors has been the offering of bank-sponsored investment management services. Various competitors have raised numerous questions about these services, with allegations ranging from unlawful behavior to unfair competition. As a result, particular bank-sponsored investment management services have been considered in a variety of forums: in administrative proceedings before the Securities and Exchange Commission (SEC or Commission), ${ }^{1}$ the Board of Governors of the Federal Reserve System (Federal Reserve Board) ${ }^{2}$ and the Comptroller of the Currency; ${ }^{3}$ in congressional hearings; ${ }^{4}$ and in litigation before Federal district courts, ${ }^{5}$ United States circuit courts of appeal, ${ }^{6}$ and the United States Supreme Court. ${ }^{7}$ In this manner, and especially during 1970-1971, the status of several of the services under the federal securities and banking laws was clarified.

Still outstanding, however, are two major suits begun in 1974 respecting two particular bank investment services. ${ }^{8}$ Moreover, the recent emerg-

1. In re First Nat'l City Bank (Commingled Inv. Account), SEC Adm. Proc. File No. 3280, Application No. 812-1823, dated Aug. 24, 1965 (application for exemptions); SEC Investment Company Act Release No. 4538 (Mar. 9, 1966), [1964-1966 Transfer Binder] FED. SEC. L. REP. (CCH) I 77,332 (order granting exemptions).

2. 37 Fed. Reg. 1463, 1464 (1972) (adoption of 12 C.F.R. \$\$ 225.4(a)(5)(ii) \& 225.125); 36 Fed. Reg. 16695 (1971) (notice of proposed list of permissible non-banking activities under Regulation $Y$ ).

3. 28 Fed. Reg. 3309 (1963) (adoption of 12 C.F.R. \$9); see Saxon, New Trust Regulations Proposed, 102 TR. \& EsT. 95 (1963).

4. Hearing on Amendment No. 438 to S. 1659 Before the Senate Comm. on Banking \& Currency, 90th Cong., 1st Sess., pt. 3 (1967); S. 2704 Hearings; The Bank Collective Investment Fund Act: Hearings on H.R. 8499 and H.R. 9410 Before a Subcomm. on Commerce \& Finance of the House Comm. on Interstate \& Foreign Commerce, 88th Cong., 2d sess. (1964); Fascell 1963 Hearing.

5. Investment Co. Inst. v. Board of Governors of Fed. Res. Sys., 398 F.Supp. 725 (D.D.C. 1975) (investment adviser to investment company); Investment Co. Inst. v. Camp, 274 F.Supp. 624 (D.D.C. 1967) (commingled managing agency accounts); SEC v. First Nat'l City Bank, SEC Litigation Release No. 4534 (Feb. 6, 1970), [1969-1970 Transfer Binder] FED. SEC. L. REP. (CCH) ๆ 92,592 (mini-accounts); $c f$. New York Stock Exch., Inc. v. Smith, 404 F.Supp. 1091 (D.D.C. 1975) (automatic investment service).

6. Investment Co. Inst. v. Board of Governors of Fed. Res. Sys., 551 F.2d 1270 (D.C. Cir. 1977) (investment adviser to investment company); National Ass'n of Sec. Dealers, Inc. v. SEC, 420 F.2d 83 (D.C. Cir. 1969) (commingled managing agency accounts); cf. New York Stock Exch., Inc. v. Bloom, 562 F.2d 736 (D.C. Cir. 1977), cert. denied, 46 U.S.L.W. 3599 (U.S. Mar. 27, 1978) (automatic investment service).

7. Investment Co. Inst. v. Camp, 401 U.S. 617 (1971) (commingled managing agency accounts).

8. In May 1974, the Investment Company Institute sued the Federal Reserve Board seeking a declaratory judgment that the relevant provisions of Regulation $\mathrm{Y}$ permitting a bank to act as an investment adviser to an investment company violated sections 16 and 21 of the 
ence of banks as serious competitors in the providing of crucial investment services, a business previously dominated by the securities industry, caused Congress in May $1975,{ }^{9}$ to direct the $\mathrm{SEC}^{10}$ to consider the appropriateness of the statutory exclusion for banks from the definitions of broker and dealer in the Securities Exchange Act of $1934 .{ }^{11}$ In the first half of 1977 the SEC submitted several reports to Congress with its analysis of the data and conclusions, and corrective legislation has been introduced. ${ }^{12}$ At least one congressional committee is itself in the process of making extensive studies of the public policy implications of particular bank-sponsored investment management services. ${ }^{13}$ Finally, Professor Louis Loss, Reporter for the

Glass-Steagall Act. Investment Co. Inst. v. Board of Governors of Fed. Res. Sys., 398 F.Supp. 725 (D.D.C. 1975) (dismissed for lack of subject matter jurisdiction), aff'd, 551 F.2d 1270 (D.C. Cir. 1977) (Federal Reserve Board action could have been challenged through timely petition in court of appeals; suggests re-petition of Federal Reserve Board). In September 1974, the New York Stock Exchange and Investment Company Institute sued the Comptroller of the Currency seeking a declaratory judgment that the Comptroller's decision to permit the offering of the automatic investment service violated the Glass-Steagall Act. New York Stock Exch., Inc. v. Smith, 404 F.Supp. 1091 (D.D.C. 1975) (Comptroller's decision upheld), vacated sub nom. New York Stock Exch., Inc. v. Bloom, 562 F.2d 736 (D.C. Cir. 1977) (Comptroller's opinion not ripe for review; remanded with instructions to dismiss the complaint), cert. denied, 46 U.S.L.W. 3599 (U.S. Mar. 27, 1978).

9. Securities Acts Amendments of 1975 , Pub. L. No. 94-29, $§ 7,89$ Stat. 163 (codified at 15 U.S.C. $\$ 78$ k-l(e) (Supp. V 1975)). See H.R. REP. No. 229, 94th Cong., 1st Sess. 109-10 (1975). The SEC's report was due December 31, 1976.

10. The SEC had already begun its own more limited inquiry. SEC Securities Act Release No. 5491 (Apr. 30, 1974), [1973-1974 Transfer Binder] FED. SEc. L. Rep. (CCH) I 79,767. See Evans, Regulation of Bank Securities Activities, 91 Banking L.J. 611 (1974).

11. The definitions of "broker" and "dealer" in sections $3(a)(4)$ and $3(a)(5)$, respectively, of the Securities Exchange Act of 1934, 15 U.S.C. $\$ \S 78 c(a)(4), c(a)(5)(1970)$, both exclude "a bank." "Bank" is defined in section 3(a)(6) to mean a national bank, a member bank of the Federal Reserve System, and a state-chartered bank. $I d$. $\S 78 \mathrm{c}(\mathrm{a})(6)$.

12. Initial SEC Bank Study Report; Second SEC Bank Study Report; Final SEC Bank Study Report. See SEC Advocates Tighter Control of Bank Activity, Wall St. J., July 1, 1977, at 8, col. 3. At Senator Williams' request, the SEC subsequently drafted a bill to implement its recommendations, which Senator Williams then introduced. S. 2131, 95th Cong., 1st Sess. (1977). Senator Williams also requested each federal bank regulatory agency to adopt voluntarily rules governing bank execution of brokerage transactions, and they have begun to propose such regulations. See Fed Proposes Record-Keeping, Confirmation Requirements for Bank Securities Activities, 439 Sec. Reg. \& L. Rep. (BNA) A-4 to A-5 (Feb. 8, 1978).

13. Senate Comm. on Banking, Housing \& Urban affairs, 94th Cong., 1st Sess., Compendium of Major Issues in Bank Regulation (Comm. Print 1975); Subcomm. on Securities of the Senate Comm. on Banking, Housing \& URban Affairs, 94th Cono., 1ST Sess., Study Outline on the Securities Activities of Commercial Banks (Comm. Print 1975); Hearings on the Expansion of Commercial Banks' Securities Business Operations and the Elimination of Barriers Between the Banking and Securities Industries Before the Subcomm. on Securities of the Senate Comm. on Banking, Housing \& Urban Affairs, 94th Cong., 1st Sess. (1975); Hearings in Furtherance of the Study of the Securities Activities of Commercial Banks Before the Subcomm. on Securities of the Senate Comm. on Banking, Honsing \& Urban Affairs, 94th Cong., 2d Sess. (1976). 
American Law Institute's Federal Securities Code (ALI Code) Project, ${ }^{14}$ and Professor Victor Brudney, Assistant Reporter for the ALI Code's investment company portion, recently published a formal tentative draft of the ALI Code including regulation of many investment management services. ${ }^{15}$ Thus, the next several years hold significant promise of being a watershed in resolution of many remaining areas of controversy in the offering of banksponsored investment management services. ${ }^{16}$

This Article will begin with a brief legal history and analysis of the present statutory framework of the federal securities and banking laws applicable to the five major bank-sponsored investment management services: common trust funds, commingled managing agency accounts, investment advisers to investment companies, corporate employee benefit and Keogh plan trusts, and mini-accounts. Because of the substantial overlap of federal regulatory agency responsibility in the existing statutory framework for these services, the second section of this Article will compare major components of the investor protection schemes provided by the federal securities and banking laws as applied to the five major bank services. Finally, the third section will suggest certain legislative changes to and statutory interpretations of the federal securities and banking laws for consideration by the ALI, the SEC and Congress. The suggestions made in this Article will attempt to reconcile the historic public policy dilemma in striking a proper balance between encouraging increased economic competition among persons offering comparable investment management services and establishing a regulatory environment which provides necessary inves-

14. Loss, The American Law Institute Federal Securities Code Project, 25 Bus. Law. 27 (1969). To date, six tentative drafts of portions of the ALI Code have been published.

15. ALI FED. SEC. CODE §§ 913A-914 (mini-accounts), 1101-1122 (investment companies) (Tent. Draft No. 6, 1977). Part XI of the ALI Code will deal with investment companies; Part VII will consolidate the registration provisions for brokers, dealers and investment advisers. With Alan Rosenblat, the author has already made a number of recommendations respecting the ALI Code's provisions regulating investment companies, investment advisers and certain other external investment management arrangements similar to investment companies. Rosenblat \& Lybecker 587.

16. Considerable attention is being devoted by others to brokerage services offered by banks, such as dividend reinvestment plans and the automatic investment service, which will not be discussed here. For a general overview, see Greenberg, Banks and the Federal Securities Laws: Some Recent Developments, 49 S. CAL. L. REv. 665 (1976); the Initial, Second and Final SEC Bank Study Reports. Generally, such brokerage services can be distinguished from investment management services in that they do not involve the creation of a security separate from the underlying security in which the parties are investing, thereby simplifying the legal relationships and express or implied fiduciary duties between the parties. See SEC Securities Act Release No. 4790 (July 13, 1965), 1 FED. SEC. L. REP. (CCH) ๆ 1131-33 (employee stock purchase plans); Letter from SEC Division of Investment Management Regulation to Lucky Stores, Inc. (June 5, 1974), [1974-1975 Transfer Binder] FED. SEC. L. REP. (CCH) \& 79,903 (dividend reinvestment plans); Letter from SEC Division of Investment Management Regulation to Sullivan \& Worcester re Investment Data Corp. (May 12, 1973), [1973 Transfer Binder] FED. SEC. L. REP. (CCH) I 79,411 (automatic investment service). 
tor protections while avoiding undue risks to the soundness of the commercial banking system.

\section{DESCRIPTION OF MAJOR BANK-SPONSORED INVESTMENT MANAGEMENT SERVICES ${ }^{17}$}

\section{A. Common Trust Funds. ${ }^{18}$}

Until the late 1920's and early 1930's, trust accounts requiring investment discretion were administered largely on an individual basis, thereby effectively limiting such services to those trust accounts large enough to bear the costs. As an alternative to the higher cost of individualized investment management treatment, and to achieve greater efficiencies and cost savings sufficient to permit penetration of the smaller trust market, trust institutions considered collective investment of multiple trusts. Such efforts, however, posed difficult state trust law ${ }^{19}$ and federal income tax law problems. ${ }^{20}$ By the mid-1930's, however, the trust industry had overcome the state trust law ${ }^{21}$ and federal income tax law ${ }^{22}$ problems and, through collec-

17. For a more comprehensive treatment of the legal history and current statutory analysis of these five major bank-sponsored investment management services, see Lybecker, BankSponsored Investment Management Services: A Legal History and Statutory Interpretive Analysis (pts. I \& II), 5 SEC. REg. L.J. 110, 195 (1977).

18. See generally, Symposium, The Investment of Trust Funds, 5 LAW \& CONTEMP. ProB. 335 (1938); Investments by Fiduciaries in Common Trust Funds, 11 REAL Prop., Prop. \& Tr. J. 28 (1976); Saxon \& Miller, Common Trust Funds, 53 GEo. L.J. 994 (1965).

19. Classic trust law prohibited the mingling of trust funds by a trustee with his own funds or those of other trusts as a part of the more general prohibition against self-dealing by a trustee. Compare RESTATEMENT OF TRusts $\$ 179$ (1935) with id. $\S 170$. See G. Bogert, LAw OF TRusts AND TRUSTEES $\S 676$, at 2026 (1935). See also Circular No. 10, Series of 1915, Federal Reserve Board, Feb. 15, 1915, 1 Fed. Res. Bull. 42 (1915). For a discussion of exceptions permitting national bank trust departments to pool cash balances of several trusts to buy and hold large-denomination Liberty Bonds, see 19 Fed. Res. Bull. 187-88 (1933); Fed. Res. Reg. F., $\S 10($ c), 1 Fed. Reg. 417, 420 (1936) (current provisions at 12 C.F.R. \$ 9.18(1977)); Saxon \& Miller, supra note 18 , at $995-96$.

20. The question was the appropriate characterization of a common trust fund: an ordinary trust with flow-through tax treatment or an association (corporation). The question was answered definitively in Brooklyn Trust Co. v. Commissioner, 80 F.2d 865 (2d Cir.), cert. denied, 298 U.S. 659 (1936) (Brooklyn Trust Company's Composite Fund, Series A, held subject to federal income tax as an association). See Capron, The Federal Reserve Board Regulations of Common Trust Funds, 5 LAW \& CONTEMP. PROB. 439 (1938).

21. Many states adopted statutes in the 1930's authorizing corporate trustees to set up common trust funds. See, e.g., Bogue, Common Trust Fund Legislation, 5 Law \& ConTEMP. ProB. 439 (1938); Note, Legislation, The Common Trust Fund Statutes-A Legalization of Commingling, 37 Colum. L. REv. 1384 (1937).

22. Congress overruled the Brooklyn Trust case by adopting section 169 in the Revenue Act of 1936, Ch. $690, \S 169,49$ Stat. 1648. See Saxon \& Miller, supra note 18, at 1003-09. The effect of section 169 was to treat common trust funds as conventional trusts, exempted as entities from federal income taxation. The current exemptive provisions are found in I.R.C. section 584, and are virtually identical to section 169 . The exemption was conditioned upon compliance with applicable rules of the Federal Reserve Board, now of the Comptroller of the Currency. 
tive investment management of trust assets, began offering conventional trust services requiring investment management discretion to persons with smaller and smaller amounts of assets to manage. ${ }^{23}$ The first full-blown regulatory scheme for collective investment was adopted in 1937 when the Federal Reserve Board amended its Regulation F, the omnibus national bank trust department rules, ${ }^{24}$ to permit national banks to operate collective investment funds where they are in the furtherance of "bona fide fiduciary purposes" and not solely as vehicles for investment purposes. ${ }^{25}$

In the course of its massive study of investment trusts and investment companies, ${ }^{26}$ the SEC from 1938 to 1939 studied what were becoming popularly known as common trust funds. ${ }^{27}$ Because of the operational similarity between investment trusts and common trust funds, both the SEC and the trust industry recognized that common trust funds would surely be covered by the SEC's proposed investment company legislation. However,

23. By $1935,73 \%$ of the individual trust accounts in the fifteen common trust funds sampled were valued at less than $\$ 5,000$ and $85 \%$ of the individual participating estates were valued at less than $\$ 10,000$; there were sixteen common trust funds in existence with total assets of approximately $\$ 38$ million. SeCurities \& EXCHANGE COMM'N, COMMINGLED OR COMMON Trust Funds Administered by Banks and Trust COMPANiEs, H.R. Doc. No. 476, 76th Cong., 3d Sess. 3, 4 (1939).

24. Fed. Res. Reg. F, § 17, 2 Fed. Reg. 2976 (1937) (current provisions at 12 C.F.R. $\$ 9.18$ (1977)); see Capron, supra note 20. These amendments to Regulation $F$ were, of course, necessary to implement section 169 of the Internal Revenue Act of 1936.

Under section $17(\mathrm{~b})$, banks were authorized to invest collectively small cash balances of trust accounts which were too small to be invested separately. Under the more general provisions of section $17(\mathrm{c})$, a common trust fund was to be administered pursuant to a written plan, a trust investment committee was to approve individual participations, the common trust fund was to be audited annually and its assets valued periodically, and the sponsoring bank was not permitted to charge a separate fee for management of the common trust fund. Fed. Res. Reg. F, \& 17, 2 Fed. Reg. 2976-77 (1937).

25. Fed. Res. Reg. F, § 17(a), 2 Fed. Reg. 2976 (1937); see Capron, supra note 20, at 446-47 (discussion of limited use of revocable trusts, prohibition on issuance of negotiable or assignable interests, notice of intent to participate or withdraw, and prohibition on investment by single trust of more than $10 \%$ of value of the common trust funds). For examples of contemporaneous discussions of the drafting of Regulation F, see [1937] ANN. REP. OF BOARD OF Governors of FEDERAL RESERve SySTEM 209-10; Trends in the Trust Field, 65 Tr. COMPANIES 215, 216 (1937); Barclay, Common Trust Fund a Reality, 66 Tr. CoMpaniEs 17, 18 (1938); Fletcher, Legal Uncertainties Point to Slow Development, 67 TR. CoMpaNiEs 162, 165 (1938); Wyat, Common Trust Funds-Symposium, Explanation of New Regulations, 66 TR. COMPANIEs 209, 211 (1938) (General Counsel of Federal Reserve Board).

26. Securimes \& Exchange Comm'N, Report on the Study of Investment Companies (1938-1942). The study appears in a number of parts as House of Representatives Documents beginning with the third session of the seventy-fifth Congress (1938) and ending with the first session of the seventy-seventh Congress (1942). See note 30 infra.

27. Securities \& Exchange Comm'n, Commingled or Common Trust Funds AdminisTERED BY BANKS AND TRUST COMPANIES, H.R. DoC. No. 476, supra note 23. The SEC report discussed the historical development of common trust funds, their legal structure, their investment policy and performance, and their regulation. Appended to the SEC's report are section 17 of the Federal Reserve Board Regulation F and eight representative state statutes relating to common trust funds. 
both supported explicit statutory exclusion of common trust funds from the definition of investment company ${ }^{28}$ in section $3(c)(3)^{29}$ of the Investment Company Act of $1940,{ }^{30}$ based vaguely on notions of avoiding "duplication of supervision." 31 After the promulgation of section 3(c)(3), there was relatively little interpretive ${ }^{32}$ or legislative activity regarding the status of

28. Most all types of collective investment vehicles fall within the definition of investment company in section 3(a)(1) of the Investment Company Act of 1940, 15 U.S.C. $\$ 80 a-3(a)(1)$ (1970), and would be required to register and comply with the regulatory provisions of the Investment Company Act unless excluded from the definition of investment company by a paragraph in sections $3(\mathrm{~b}), 3(\mathrm{c})$ or 6 .

29. Id. $\S 80 \mathrm{a}-3(\mathrm{c})(3)$. The first bill proposing an Investment Company Act would have excluded "any common trust fund, as defined in section 169 of the Revenue Act of 1938." S. 3580, 76th Cong., 3d Sess. § 3(c)(3) (1940); Hearings on S. 3850 Before a Subcomm. of the Senate Comm. on Banking \& Currency, 76th Cong., 3d Sess. 181 (1940); cf. id. $925-29$ (letters dated Apr. 18, Apr. 19 and Apr. 20, 1940 between the SEC, Board of Governors of Federal Reserve System and Senator Wagner, chairman of the Committee, respecting amendments to place holding companies investing in banks under the Federal Reserve Board to avoid "duplication of supervision"). The second bill, prepared jointly by the SEC and representatives of the investment company industry, excluded "any common trust fund or similar fund maintained by a bank exclusively for the collective investment and reinvestment of moneys contributed thereto by the bank in its capacity as a trustee, executor, administrator, or guardian." S. 4108, 76th Cong., 3d Sess. § 3(c)(3) (1940); S. Rep. No. 1775, 76th Cong., 3d Sess. 12-13 (1940) (to accompany S. 4108). Thus section 3(c)(3) and section 169 employed identical terminology in providing special treatment for common trust funds under the federal securities and tax laws. There was no comment on section 3(c)(3) in the Senate hearings on S. 4108, or in the House hearings on the parallel bill, H.R. 10065, Hearings on S. 3580 Before a Subcomm. of the Senate Comm. on Banking \& Currency, supra, pt. 4; Hearings on H.R. 10065 Before the Subcomm. of the House Comm. on Interstate \& Foreign Comm., 76th Cong., 3d Sess. (1940), and the House committee report to accompany H.R. 10065 described the section 3(c)(3) exclusion in precisely the same manner as the Senate committee report. Compare S. REP. No. 1775, supra, at 12-14, with H.R. REP. No. 2639, 76th Cong., 3d Sess. 12 (1940). Finally, there was no mention of section 3(c)(3) in the Senate or House floor debates. 86 CoNG. REC. 15413-21 (1940) (Senate floor debate); 86 CONG. REC. 15691-93 (1940) (House floor debate).

30. Investment Company Act of 1940 , ch. 686,54 Stat. 789 (codified at 15 U.S.C. $\$ 80 a-1$ to a-52 (1970)). For detailed reviews of the legislative history of the Investment Company Act, see Farina, Freeman, \& Webster, The Mutual Fund Industry: A Legal Survey, 44 Notre Dame LAIv. 732, 794-808 (1969); North, A Brief History of Federal Investment Company Legislation, 44 Notre Dame Law. 67 (1969).

31. Hearings on S. 3580 Before a Subcomm. of the Senate Comm. on Banking \& Currency, supra note 29, pt. 2, at 925-29 (letters dated Apr. 18, Apr. 19, Apr. 20 and Apr. 22, 1940 between the SEC, the Board of Governors of the Federal Reserve System and Senator Wagner, chairman of the Committee).

32. See 25 Fed. Reg. 12479 (1960) (proposed further limitation in Federal Reserve Board Regulation $F$ \& 17(a)(3) regarding use in common trust fund of inter vivos trust revocable by the settlor and providing for payment of principal to settlor's estate at his death). See also 42 Fed. Res. Bull. 228 (1956); 41 Fed. Res. Bull. 142 (1955); 26 Fed. Res. Bull. 390, $393-94$ (1940) (Federal Reserve Board reminders that common trust funds were intended to be a tool in trust administration and not a medium for the speculative investment of funds in the absence of traditional trust purposes).

Finally, as some banks will always be too small to make use effectively of the economies of scale in managing internally-created common trust funds, at least two funds (Bank Fiduciary Fund, Inc. and Connecticut Fiduciaries' Fund, Inc.) were organized in the mid-1950's as 
common trust funds until 1962 when the banking industry finally prevailed upon Congress to have regulatory responsibility for the trust powers of national banks transferred from the Federal Reserve Board to the Comptroller of the Currency. ${ }^{33}$

The Comptroller of the Currency quickly and substantially revised the rules governing the collective investment of trust funds ${ }^{34}$ by authorizing the pooling of managing agency accounts $\mathrm{s}^{35}$ and by deleting the requirement that an independent "bona fide fiduciary purpose" exist for establishing the investment advisory relationship. ${ }^{36}$ Such an enormous loosening of regulation of common trust funds caused immediate and widespread concern, and

registered investment companies subject to I.R.C. $\$ 851$ but complying voluntarily with Federal Reserve Board Regulation F, applicable to such "orphan" banks. See Treman, A Bank Fiduciary Fund for Multiple Bank Participation, 98 TR. \& EST. 244 (1959).

33. Act of Sept. 28, 1962, Pub. L. No. 87-722, 76 Stat. 668 (codified at 12 U.S.C. \$ 92a (a) (1970)). See Authority over the Trust Powers of National Banks and National Bank Branches: Hearings on H.R. 12577 \& H.R. 12825 Before Subcomm. No. 1 of the House Comm. on Banking \& Currency, 87th Cong., 2d Sess. (1962); S. REP. No. 2039, 87th Cong., 2d Sess., reprinted in [1962] U.S. Code Cong. \& AD. News 2735; Report of THE AdVisory CoMm. on BanKing to THE Comptroller of the CuRRENCY, National Banks AND tHe Future 31-37 (1962). For a condensed litany of the complaints against the Federal Reserve Board's oversight of trust operations, see Wolfe, Wider Horizons for Common Trust Funds, 101 TR. \& EsT. 1075 (1962). The Federal Reserve Board's Regulation $\mathrm{F}$ was, however, initially republished virtually intact as section 17 of the Comptroller of the Currency's Regulation 9.27 Fed. Reg. 9767 (1962).

34. Regulation 9, § 9.18, 28 Fed. Reg. 3311 (1963).

35. "Managing agency accounts" are investment advisory or investment management arrangements where something less than the usual trustee-type relationship is created. They are the functional equivalents of investment advisory services provided by broker-dealers or investment advisers, differing among themselves perhaps only in terms of whether the provider of the service also retains custody and safe-keeping duties with respect to the account's assets. The Federal Reserve Board had long permitted national banks to operate managing agency accounts, but not on a collective investment basis. See, e.g., 25 Fed. Reg. 12479 (1960); 42 Fed. Res. Bull. 228 (1956); 41 Fed. Res. Bull. 142 (1955); 26 Fed. Res. Bull. 393 (1940).

The pooling of managing agency accounts was permitted by the Comptroller of the Currency by adding to the definition describing conventional common trust funds in section 9.18 a new third clause ((a)(3)) addressed to common trust funds relating to the "new" fiduciary relationship of managing agent. Regulation 9, §§ 9.18(a)(3), 9.1(g), 28 Fed. Reg. 3311, 3309 (1963) (definitions of a common trust fund for managing agency accounts and of managing agent). As to whether commingled managing agency accounts were deemed to be "common trust funds" within the meaning of section 584 of the Internal Revenue Code of 1954, see Rev. Rul. 64-59, 1964-1 C.B. 193. See also Memorandum from Mortimer M. Caplin, Commissioner of Internal Revenue, to James T. Saxon, Comptroller of the Currency (Jan. 19, 1964) (re qualification as a "Common Trust Fund" within the meaning of section 584 of the Internal Revenue Code of 1954), reprinted in S. 2704 Hearings 600-01.

36. See Saxon, supra note 3, at 136. But see Judd, Common Trust Funds Under New Regulation 9, 102 TR. \& EST. 569, 569-70 (1963).

The definition of "fiduciary" in Regulation 9, § 9.1(b), was also amended expansively to include the relationship of managing agent, thereby bringing such activities within the conventional regulatory provisions for trust-like arrangements, now expressed in sections 9.7-.15, respecting bank administration, books and records, audits, self-dealing, custody, and compensation, Regulation 9, §§ 9.7-.15, 28 Fed. Reg. 3310-11 (1963). 
prompted the convening of congressional oversight hearings ${ }^{37}$ In addition, various bills were introduced to codify explicitly the Comptroller's view of the legal status of commingled managing agency accounts as outside the federal securities laws. ${ }^{38}$ SEC Chairman William L. Cary testified at the subsequent congressional hearings that the common trust fund exclusion in section 3(c)(3) of the Investment Company Act would not be available for commingled managing agency accounts because the exclusion rested on the premise "that the traditional common trust fund as circumscribed by the Federal Reserve Board could be used only for bona fide fiduciary purposes and not as a vehicle for general investment by the public."39 The SEC's interpretation of section 3(c)(3) as inapplicable to commingled managing agency accounts prevailed by default when in 1965 First National City Bank in effect conceded jurisdiction and filed an application under section 6(c) of the Investment Company Act of 1940 to obtain an exemption for its

37. Fascell 1963 Hearing. See RePORT BY THE House COMM. ON GovernMENT OPERATIONS, Common TRUST FundS-Overlapping Responsibility and Conflict in REgulations, H.R. REP. No. 429, 88th Cong., 1st Sess. (1963) (recommending legislation to exempt commingled managing agency accounts from the federal securities laws but provide appropriate and necessary investor protections).

38. Bank Collective Investment Fund Act, S. 2223, 88th Cong., 1st Sess. (1963), H.R. 8499 \& H.R. 9410, 88th Cong., 1st Sess. (1963). The Bank Collective Investment Fund Act of 1963 would have amended section 2(1) of the Securities Act of 1933, 15 U.S.C. $\$ 77 \mathrm{~b}(1)$ (1970), section 3(a)(10) of the Securities Exchange Act of 1934, id. $\S 78 \mathrm{c}(\mathrm{a})(10)$, and section 3(c)(3) of the Investment Company Act, $i d . \S 80 \mathrm{a}-3(\mathrm{c})(3)$, to exclude therefrom interests in any collective investment fund, and, to the extent the provisions of Regulation 9 were not already codified in the proposed Act, would have provided regulatory rulemaking power to be exercised by the Comptroller of the Currency. See 110 CoNG. REC. 833-34 (1964) (letter from James J. Saxon, Comptroller of the Currency, to Senator Robertson supporting S. 2223 (Jan. 20, 1964)).

39. Fascell 1963 Hearing 3 (testimony of SEC Chairman Cary). Chairman Cary noted in his testimony that the Federal Reserve Board had previously halted a similar scheme of the First National Bank of Forth Worth involving newspaper advertisements seeking subscriptions to its common trust fund with a minimum initial payment of $\$ 100$ and subsequent monthly payments of \$25. Id. 5. See also Hearings on S. 1642 Before a Subcomm. of the Senate Comm. on Banking \& Currency, 88th Cong., 1st Sess. 54-55 (1963) (testimony of SEC Chairman Cary). But see Fascell 1963 Hearing 33-37 (testimony and memorandum of Comptroller of the Currency Saxon).

The most probable explanation for the Comptroller's difficulties with the Commission's position-that banks must register the commingled managing agency aecounts under the Investment Company Act-was that compliance would seemingly constitute an admission (a) that the operation of commingled managing agency funds involved the issuanee of a security by a registered investment company, not the bank, and (b) that the security was being publicly offered by the commingled managing agency account as the issuer and by the bank as a defacto underwriter of equity securities. Cf. SEC v. Variable Annuity Life Ins. Co. of America, 359 U.S. 65 (1959) (interest in a variable annuity fund is a security); Prudential Ins. Co. of America v. SEC, 326 F.2d 383 (3d Cir.), cert. denied, 377 U.S. 953 (1964) (variable annuity separate account is an issuer of securities separate from the insurance company). Would it not necessarily follow that such a bank would be engaged in the business of underwriting cquity securities as prohibited by the Glass-Steagall Act? See Mundheim \& Henderson, Applicability of the Federal Securities Laws to Pension and Profit-Sharing Plans, 29 LAW \& CONTEMP. ProB. 795, 824-25 (1964). 
commingled investment account from certain specific regulatory provisions. ${ }^{40}$

The phrase "common trust fund" in section 3(c)(3) of the Investment Company Act and section 3(a)(2) of the Securities Act of $1933^{41}$ should, then, be read to exclude from the operative registration and regulatory provisions of those Acts only those common trust funds $\mathrm{s}^{42}$ which are maintained by a bank exclusively for bona fide fiduciary purposes in its tradition-

40. In re First Nat'1 City Bank (Commingled Inv. Account), Adm. Proc. File No. 3-280, Application No. 812-1823, dated Aug. 24, 1965. The requested exemptions were subsequently granted by the Commission. SEC Investment Company Act Release No. 4538 (Mar. 9, 1966), [1964-1966 Transfer Binder] FED. SEC. L. REP. (CCH) ๆ 77,332.

41. The applicable provisions of section 3(a)(2) of the Securities Act of 1933 were added by Investment Company Amendments Act of 1970, Pub. L. No. 91-547, § 27(b), 84 Stat. 14 (codified at 15 U.S.C. $\S 77 \mathrm{c}(\mathrm{a})(2)(1970)$ ). Prior to that time, there had been no express exemption for common trust funds from section 5 of the Securities Act, 15 U.S.C. $\$ 77 \mathrm{e}$ (1970), but the Commission and banking industry had generally believed that operation of a common trust fund would fall within section 4(2) of the Securities Act of 1933, id. $\$ 77 \mathrm{~d}(2)$, for offerings not involving a public offering. Fascell 1963 Hearing 4 (testimony of SEC Chairman Cary); Hearings on H.R. 14742 Before the Subcomm. on Commerce \& Finance of the House Comm. on Interstate \& Foreign Commerce, 90th Cong., 1st Sess. 31-33 (1968) (testimony of Robert D. Ferguson, representing the American Bankers Ass'n; testimony of SEC Chairman Cohen). In any event, Congress clearly intended section $3(a)(2)$ to be interpreted in the same manner as section 3(c)(3). See, e.g., S. REP. No. 184, 91st Cong., 1st Sess. 27 (1969); S. REP. No. 1351, 90th Cong., 1st Sess. 25 (1968); H.R. REP. No. 1382, 91st Cong., 2d Sess. 43 (1970); see SEC v. Heritage Trust Co., [1975-1976 Transfer Binder] FED. SEC. L. REP. (CCH) I 95,282 (D. Ariz. 1975) (trust agreements conferring absolute investment discretion without usual standard of safety characteristic of bona fide fiduciary relationship cannot rely on section 3(a)(2); receiver appointed).

The Commission recently delegated to the Director of the Division of Investment Management the authority to issue notices and orders under section 3(a)(2). SEC Securities Act Release No. 5894 (Dec. 23, 1977), [Current] FED. SEC. L. ReP. (CCH) ๆ 81,394.

42. The phrase "or similar fund" which is now found in section $3(a)(2)$, section $3(c)(3)$ and I.R.C. $\$ 851(\mathrm{a})(2)$ should be deleted because it no longer has any useful meaning; moreover, to the extent a "similar fund" somewhere presently exists which is thereby able to escape regulation either as an investment company or as a common trust fund, such a loophole should be definitively closed.

Pub. L. No. 94-414, § 1, 90 Stat. 1273 (1976) amended I.R.C. \$ 584(a) to permit affiliated banks to establish as a group common trust funds to be treated for tax purposes as if done by one bank. See Miscellaneous Minor Tax Bills: Hearings on H.R. 5071 Before the House Comm. on Ways and Means, 94th Cong., 1st Sess. (1975). The SEC staff had earlier taken a no-action position respecting Investment Advisers Act $\S 202(a)(11)$ to a bank wishing to advise all trust subsidiaries of a bank holding company which is consistent with I.R.C. $\$$ 584(a), as amended. Letter from SEC Division of Investment Management Regulation to Marine Midland Banks, Inc. (Mar. 9, 1973). One thus would expect the Commission, upon request, to take a favorable position respecting the applicability of Investment Company Act $\$ 3(c)(3)$ and Securities Act $\S$ $3(a)(2)$ to group common trust funds. See, e.g., SEC Investment Company Act Release No. 9966 (Oct. 31, 1977), [Current] FED. SEC. L. REP. (CCH) ๆ 81,353 (rule proposals); SEC Investment Company Act Release No. 10089 (Jan. 10, 1978), [Current] FED. SEC. L. REP. (CCH) $\pi$ 81,409 (adoption of rules 132, 12h-2 and 3c-4 under the Securities Act, Securities Exchange Act and Investment Company Act, respectively, defining multi-bank common trust funds as traditional single-bank common trust funds for purposes of the Acts). See Certain Banks Funds Get Equal Treatment Under New SEC Rule, Wall St. J., Jan. 13, 1978, at 2, col. 3. 
al capacity as trustee, executor, administrator or guardian. ${ }^{43}$ But even if interests in a common trust fund and the common trust fund itself are excluded from the operative registration and regulatory provisions of the Securities Act of 1933 and the Investment Company Act, the purchase or sale of such interests would in any event still be subject to the general antifraud provisions of section 17(a) of the Securities Act and section 10(b) (and rule 10b-5 thereunder) of the Securities Exchange Act, ${ }^{44}$ since operation of a common trust fund would involve the offering of a security.

\section{B. Commingled Managing Agency Accounts; Investment Adviser to Investment Company.}

\section{The Citibank Application, Congressional Hearings, and Litigation.}

As noted above, in August 1965 First National City Bank filed its application under section 6(c) for exemption from certain provisions of the Investment Company Act for its commingled managing agency accounts. ${ }^{45}$

43. To the author's knowledge, there has only been one major test of this formulation since the mid-1960's, involving "mini-trusts" services recently offered by several major banksContinental Illinois National Bank and Trust Co., Manufacturers Hanover Trust Co. and Chase Manhattan Bank. The service generally consists of five to eight standardized inter vivos trust instruments (prepared by the bank and distributed to area lawyers) which provide for a life estate in the grantor, remainder to various family members pursuant to particular estate planning considerations. See Cole, Personal Finance: Minitrusts Growing, N.Y. Times, Nov. 12,1973 , at 53, col. 3. While the mini-trusts are standardized to permit ease of administration of trusts at substantially lower levels of assets (down to $\$ 10,000$ ) and investment management through collective investment in a bank's common trust funds, the standardized forms are merchandized only to attorneys, and the various estate planning alternative arrangements provided in the specimen agreements appear clearly to be within the scope of "bona fide fiduciary purpose." Although a purist might object (as the Federal Reserve Board proposed in 1960, see note 32 supra) to a revocable mini-trust which provides for a life estate in the grantor and payment at death to the grantor's estate as being essentially equivalent to a managing agency account, a good argument can be made that the bank trustee does assume, inter alia, the obligation to consider the appropriate application of income and principal during the grantor's life and at death-significant and traditional trust powers and responsibilities. It is understood that, after reviewing the various trust documents and discussing them with appropriate bank officers and counsel, the SEC staff determined not to request that the Commission bring any enforcement action, and the banks also apparently determined not to seek any written no-action assurance from the SEC staff.

44. 15 U.S.C. $\$ \S 77 q, 78 j(b)(1970) ; 17$ C.F.R. \$ 240.10b-5 (1977). See notes 227-43 infra.

45. In re First Nat'l City Bank (Commingled Invest. Account), SEC Adm. Proc. File No. 3280, Application No. 812-1823, dated Aug. 24, 1965. The Citibank application requested exemption from Investment Company Act \$\$ 10(b)(3), 10(c), 10(d)(2), 15(a), 16(a), 17(f), 17(g) and 32(a)(2), 15 U.S.C. §§ 80a-10(b)(3), 10(c), 10(d)(2), 15(a), 16(a), 17(f), 17(g), 31(a)(2) (1970).

The Commission issued a notice of the filing of the Citibank applieation, SEC Investment Company Act Release No. 4342 (Sept. 2, 1965), and the ICI, NASD, Investment Bankers Association of America, and Association of Mutual Fund Plan Sponsors, Inc. requested a hearing on various aspects of Citibank's application. The Commission subsequently issued an order, SEC Investment Company Act Release No. 4380 (Oct. 20, 1965), establishing the procedure for filing of briefs and presentation of oral arguments. 
Senator McIntyre also introduced in October 1965 a bill attempting to exclude commingled managing agency accounts from the registration and regulatory requirements of the federal securities laws. ${ }^{46}$ However, by the time hearings on the bill were scheduled and begun in March 1966, 47 they had lost all practical meaning because the Commission was just in the process of granting the requested exemptive order to Citibank's Commingled Investment Account. ${ }^{48}$ In May 1966, moreover, the National Association of Securities Dealers, Inc. (NASD) sued the SEC to obtain judicial review of the exemptive order granted by the SEC to Citibank's Commingled Investment Account, and the Investment Company Institute (ICI) subsequently sued the Comptroller of the Currency to obtain judicial review of the provisions in Regulation 9 which permitted banks to offer commingled managing agency accounts. ${ }^{49}$ Finally, in June 1966 the SEC declared effec-

46. S. 2704, 89th Cong., 1st Sess. (1965). For a chart prepared by the SEC staff comparing (1) the Investment Company Act, the Securities Act of 1933 and the Securities Exchange Act of 1934, with (2) the Citibank application, and with (3) the provisions of S. 2704, see S. 2704 Hearings 144-71.

47. S. 2704 Hearings.

48. In re First Nat'l City Bank (Commingled Invest. Account) SEC Investment Company Act Release No. 4538 (Mar. 9, 1966), [1964-1966 Transfer Binder] FED. SEC. L. REP. (CCH) I] 77,332 . The SEC order granted all but one of the exemptions requested by Citibank, finding not supported Citibank's request under section 10(d)(2), 15 U.S.C. $\$ 80 \mathrm{a}-10 \mathrm{~d}(2)$ (1970), for variance from the statutory requirement that no more than $60 \%$ of the board of directors be affiliated with the bank. SEC Commissioner Budge dissented, being unable to conclude that Citibank had carried the burden of proof under section $6(\mathrm{c})$, id. $\S 80 \mathrm{a} 6(\mathrm{c})$, for any of its requested exemptions. The SEC subsequently issued a minor correction of Findings, Opinion, and Order, SEC Investment Company Act Release No. 4538a (Mar. 14, 1966), reprinted in Hearings on H.R. 14742 Before the Subcomm. on Commerce \& Finance of the House Comm. on Interstate \& Foreign Commerce, supra note 41 , at 131 . The NASD promptly petitioned the SEC for a rehearing; its petition was vigorously opposed by Citibank and the SEC issued an order on Apr. 6, 1966 denying the petition for rehearing. See S. 2704 Hearings $140-42$. It should be noted that the SEC in its brief to the Supreme Court in 1969 in National Ass'n of Sec. Dealers, Inc. v. SEC, 401 U.S. 617 (1971), the companion case to Investment Co. Inst. v. Camp, 401 U.S. 617 (1971), stated that " $[t]$ here is no assurance that the Commission would reach the same judgment [regarding the exemptive order] if a similar matter is again presented," citing the change of membership on the Commission since 1966. Memorandum for the Securities and Exchange Commission, at 4 n.4, National Ass'n of Sec. Dealers, Inc. v. SEC, 401 U.S. 617 (1971).

49. Citibank had earlier received clearance from the appropriate federal bank regulatory agencies. See Letter from James J. Saxon, Comptroller of the Currency, to First National City Bank (May 10, 1965), reprinted in S. 2704 Hearings 418-21 (letter of approval under section 9.18(c)(5) of Regulation 9); 12 C.F.R. $\$ 218.111$ (1977), 51 Fed. Res. Bull. 1410 (Oct. 1965), reprinted in $S$. 2704 Hearings 580-81 (ruling of July 22, 1965 that Citibank and the Commingled Investment Account were a single entity for purposes of Glass-Steagall Act $\$ 32,12$ U.S.C. $\$ 78$ (1970)); Memorandum of the Federal Reserve Board, Legal Considerations Under Section 32 of the Banking Act of 1933 in Connection with the Proposed Commingled Investment Account of First National City Bank of New York (Dec. 15, 1965), reprinted in, S. 2704 Hearings 581-88. For an analysis of Glass-Steagall Act $\S 32$ in this context, see Lehr, The Affiliation of Commercial Bank and Mutual Fund Personnel, 10 St. Louis U.L.J. 190 (1965); cf. Letter from Fred M. Vinson, Assistant Attorney General, Department of Justice, to the SEC (Jan. 24, 1966), reprinted in S. 2704 Hearings 588 (letter concluding no violation of Glass-Steagall Act $\S$ 21, 12 U.S.C. $\S 378$ (1970)). 
tive the Securities Act registration statement of Citibank's Commingled Investment Account and it began to offer and sell to the public interests in the open-end management investment company. ${ }^{50}$

In September 1967, the district court in the ICI suit held against the validity of the operative provisions of the Comptroller of the Currency's Regulation $9,^{51}$ forcing the banks quickly to shift strategy and renew their earlier legislative attack by securing introduction of amendments to the SEC's mutual fund legislation ${ }^{52}$ which would have permitted the offering of commingled managing agency accounts subject to the Citibank application formula for investor protection conditions..$^{53}$ Although the SEC's mutual fund legislation got stalled in 1968 at the tail end of the 90th Congress, ${ }^{54}$ the

50. Investment Co. Inst. v. Camp, 274 F. Supp. 624, 628 (D.D.C. 1967), rev'd sub nom. National Ass'n of Sec. Dealers v. SEC, 420 F.2d 83 (D.C. Cir. 1969), rev'd sub nom. Investment Co. Inst. v. Camp, 401 U.S. 617 (1971). For the Commingled Investment Account's notification of registration under the Investment Company Act and excerpts from its preliminary prospectus, both dated Apr. 20, 1966, see S. 2704 Hearings 659-61.

51. Investment Co. Inst. v. Camp, 274 F. Supp. 624 (D.D.C. 1967), rev'd sub nom. National Ass'n of Sec. Dealers v. SEC, 420 F.2d 83 (D.C. Cir. 1969), rev'd sub nom. Investment Co. Inst. v. Camp, 401 U.S. 617 (1971) (units of participation in commingled managing agency account are securities and bank underwriting thereof violates sections 16,32, 20 and 21 of the Glass-Steagall Act).

52. The SEC's proposed mutual fund legislation [The Investment Company Amendments Act of 1967, S. 1659, 90th Cong., 1st Sess. (1967); H.R. 9511, 90th Cong., 1st Sess. (1967) and H.R. 9510, 90th Cong., 1st Sess. (1967)] was the end product of three separate but complementary investigations: Wharton SchOol of Finance and Commerce, A Study of Mutual Funds, H.R. ReP. No. 2274, 87th Cong., 2d Sess. (1962); SeCURITIES \& EXCHANGE Comm'N, RePORT OF SPECIAL Study OF SECURITIES MARKETS, H.R. Doc. No. 95, 88th Cong., 1st Sess. (1963); and Securities \& EXChange Comm'N, Public Policy Implications of Investment COMPANY GROWTH, H.R. REP. No. 2337, 89th Cong., 2d Sess. (1966). Hearings on the initial mutual fund reform bill were held in the Senate and the House in the summer and fall of 1967, prior to the District Court decision cited in note 51 supra, with virtually no discussion of commingled managing accounts. Hearings on S. 1659 Before the Senate Comm. on Banking \& Currency, 90th Cong., 1st Sess. pts. 1 \& 2 (1967); Hearings on H.R. 9510 and H.R. 9511 Before the Subcomm. on Finance of the House Comm. on Interstate and Foreign Commerce, 90th Cong., 1st Sess. (1967).

53. Hearings on H.R. 14742 Before the Subcomm. on Commerce \& Finance of the House Comm. on Interstate \& Foreign Commerce, supra note 41; Hearing on Amendment No. 438 to S. 1659 Before the Senate Comm. Banking \& Currency, supra note 4, at pt. 3.

There is some suggestion that the SEC may have agreed not to object to the banking industry's proposed provisions if it in turn would back the proposed reforms of the mutual fund industry. JENNINGS \& MARSH 1464. For corroborative evidence, see S. REP. No. 1351, 90th Cong., 2d Sess. 2-3 (1968) (noting support of the bill by the American Bankers Ass'n); Hearing on Amendment No. 438 to S. 1659 Before the Senate Comm. on Banking \& Currency, supra note 4, at 1283 (testimony of Robert D. Ferguson, Executive Vice President, Pittsburgh National Bank; formerly President, Trust Division, American Bankers Ass'n, in support of S. 1659); Hearings on H.R. 14742 Before the Subcomm. on Commerce \& Finance of the House Comm. on Interstate \& Foreign Commerce, supra note 41, at 34 (testimony of Robert D. Ferguson, respecting the "reasonableness" standard for management fees); id. 135 (testimony of SEC Chairman Cohen).

54. The Senate passed a "clean" bill, S. 3724, which was an amalgam of the provisions in S. 1659 and Amendment No. 438 to S. 1659, but the House took no action. S. REP. No. 1351, 
banking industry continued to advance its legislative proposals in the 91 st Congress; ${ }^{55}$ the SEC's mutual fund legislation thus proceeded through the 91st Congress with the same provisions specifically aimed at commingled managing agency accounts. ${ }^{56}$ In July 1969 , the court of appeals in the ICI suit held that a national bank could lawfully offer interests in commingled managing agency accounts, ${ }^{57}$ and denied a rehearing in August 1969. ${ }^{58}$ With events accelerating rapidly, in March 1970, the United States Supreme Court granted certiorari ${ }^{59}$ and in December 1970, heard oral argument, just after the Senate and House Conference Committee determined in resolving differences between the Senate and House mutual fund reform bills to drop the provisions relating to commingled managing agency accounts. ${ }^{60}$ In April 1971, the Supreme Court in Investment Company Institute v. Camp ended

90th Cong., 2d Sess. (1968); 114 CoNG. REC. 23519-52 (1968). For a general discussion, explanation and analysis of the provisions relating to commingled managing agency accounts, see S. REP. No. 1351, 90th Cong., 2d Sess. 9-11, 19-26 (1968).

55. See Hearings on S. 34 and S. 296 Before the Senate Comm. on Banking \& Currency, 91st Cong., Ist Sess. 41-45 (1969) (testimony of Paul W. Eggers, General Counsel, Dept. of the Treasury), 69-87 (testimony of Reese H. Harris, Jr., Executive Vice President, Manufacturers Hanover Trust Co., on behalf of the American Bankers Ass'n); Hearings on H.R. 14737 Before the Subcomm. on Commerce \& Finance of the House Comm. on Interstate \& Foreign Commerce, 91st Cong., 1st Sess. pt. 1, at $463-97$ (1969) (testimony of Reese H. Harris, Jr., Executive Vice President, Manufacturers Hanover Trust Co., on behalf of the American Bankers Ass'n).

56. The Senate Committee on Banking and Currency promptly reported out a "clean" bill, S. 2224, containing the same provisions respecting commingled managing agency accounts from prior bills, although the implementing federal banking agency regulations would now be required by newly revised proposed section 22(h) of the Investment Company Act [section 12(d) of the bill] to be consistent with the broker-dealer regulatory provisions of the Securities Exchange Act. S. 2224, 91st Cong., 1st Sess. § 12(d) (1969); S. REP. No. 184, 91st Cong., 1st Sess. 10-12, 22-28 (1969). Representative Staggers introduced a "clean" bill, H.R. 17333, 91st Cong., 2d Sess. (1970), which was reported out of the House Committee on Interstate and Foreign Commerce on July 28, 1970. H.R. REP. No. 1382, 91st Cong., 2d Sess. (1970).

H.R. 17333 differed, however, in one material respect from S. 2224. The House version of new Investment Company Act $\S 22(\mathrm{~h})$ would authorize the offering of commingled managing agency accounts only if they were not prohibited by any other provision of state or federal law, while the clear intent of new section $22(\mathrm{~h})$ in S. 2224 was to override any other inconsistent provisions of state or federal law. H.R. 17333, 91st Cong., 2d Sess. § 12(d) (1970); H.R. REP. No. 1382, supra, at 9-10.

57. National Ass'n of Sec. Dealers, Inc. v. SEC, 420 F.2d 83 (D.C. Cir. 1969) (managing agency is a fiduciary relationship not intended to be covered by the Glass-Steagall Act).

58. Id.

59. 397 U.S. 986 (1970).

60. As discussed in note 56 supra, section 12(d) [new section 22(h) of the Investment Company Act] of the Senate and House bills differed respecting whether or not the Investment Company Amendments Act of 1970 would override any other inconsistent provisions of state or federal law which might prohibit the offering of commingled managing agency accounts. The Conference Committee members apparently were unable to resolve that difference, and therefore omitted from the Investment Company Amendments Act of 1970 the entire package of provisions for commingled managing agency accounts based on the Citibank application. H. R. REP. No. 1631, 91st Cong., 2d Sess. 28-29 (1970). 
the decade-long controversy by deciding entirely against the validity of offering commingled managing accounts with respect to the investment banking prohibitions in the Glass-Steagall Act. ${ }^{61}$

\section{The 1970 Bank Holding Company Act Amendments and Federal Reserve Board Regulation Y.}

During the late 1960's, while Congress was actively considering the SEC's mutual fund legislation and its impact on certain bank-sponsored investment services, it was also considering the regulatory problems raised by the emergence of the one-bank holding company structure, which (in conjunction with nonbank subsidiaries) offered the opportunity to expand into a wide variety of banking-related services without the regulatory restrictions which would otherwise have been imposed by federal banking agencies on banks and by the Federal Reserve Board on multi-bank holding companies. ${ }^{62}$ After extensive hearings and complex floor debate, the House passed a bill in November 1969.63 The Senate also held hearings and passed a bill in August 1970, ${ }^{64}$ and the resulting House and Senate Conference Committee ultimately agreed upon a bill in December $1970 .{ }^{65}$

61. 401 U.S. 617 (1971). The Court stated:

No provision of the banking law suggests that it is improper for a national bank to pool trust assets [in a common trust fund], or to act as managing agent for individual customers, or to purchase stock for the account of its customers. But the union of these powers [in a commingled managing agency fund] gives birth to an investment fund whose activities are of a different character. The differences between the investment fund that the Comptroller has authorized and a conventional open-end mutual fund are subtle at best, and it is undisputed that this bank investment fund finds itself in direct competition with the mutual fund industry. One would suppose that the business of a mutual fund consists of buying stock 'for its own account' and of 'issuing' and 'selling' 'stock' or 'other securities' evidencing an undivided and redeemable interest in the assets of the fund. On their face, $\$ \$ 16$ and 21 of the Glass-Steagall Act appear clearly to prohibit this activity by national banks.

Id. at 624-25 (Stewart, J.) (footnotes omitted).

62. See Staff of the House Comm. on Banking \& Currency, 91st Cong., ist Sess., The Growth of UnRegistered Bank Holding Companies-Problems and Prospects (Comm. Print 1969); Shapiro, The One-Bank Holding Company Movement: An Overview, 86 Banking L.J. 291 (1969). See generally G. FisCher, Bank Holding Companies (1961).

63. Hearings on H.R. 6778 Before the House Comm. on Banking \& Currency, 91st Cong., Ist Sess., pts. 1-3 (1969); H.R. ReP. No. 387, 91st Cong., Ist Sess. (1969); 115 CoNG. Rec. 32890-911, 33125-55 (1969).

64. Hearings on S. 1052, S. 1211, S. 1664, S. 3823, and H.R. 6778 Before the Senate Comm. on Banking \& Currency, 91st Cong., 2d Sess., pts. 1-2 (1970); S. REP. No. 1084, 91 st Cong., 2d Sess., reprinted in [1970] U.S. CODE CONG. \& AD. NEwS 5519; 116 CONG. REC. 31815-23, 3210437 (1970).

65. Bank Holding Company Act Amendments of 1970, Pub. L. No. 91-607, 84 Stat. 1760 (codified in scattered sections of 12 \& 31 U.S.C.). See H.R. REP. No. 1747, 91 st Cong., 2d Sess. (1970). For the spirited and acrimonious House and Senate floor debates on the conference committee's bill, see 116 CoNG. REC. $42422-38$ (1970); 116 CoNG. REC. $71979-65$ (1970). For an invaluable treatise on the legislative history of the 1970 Amendments and early subsequent interpretations by the Federal Reserve Board, see C. BLAINE, FEDERAL Regulation of BANK Holding Companies (1973). See also Legislation Note, The Bank Holding Company Act Amendments of 1970, 39 GEO. WASH. L. REv. 1200 (1971). 
The Federal Reserve Board immediately began to implement amended section 4(c)(8) of the Bank Holding Company Act by publishing proposals to amend its Regulation $\mathrm{Y}^{66}$ to permit nine specific activities-including acting generally as a fiduciary ${ }^{67}$ and as investment adviser to an investment company ${ }^{68}$ - deemed by the Board "to be so closely related to banking or managing or controlling banks as to be a proper incident thereto." 69 At hearings held by the Federal Reserve Board in November 1971,70 the Investment Company Institute and Department of Justice opposed in varying degrees, with reference to the Glass-Steagall Act, a proposal permitting bank holding companies to act as investment advisers to investment companies. ${ }^{71}$ While the Federal Reserve Board recognized the seriousness

The colloquy in the floor debate most relevant here is between Senators Williams and Sparkman, to the effect that the 1970 amendments to the Bank Holding Company Act were not intended to expand or contract the existing prohibitions of the Glass-Steagall Act, and that they were applicable to banks, bank holding companies and any affiliates of either. 116 CoNG. REC. 42430 (1970) (remarks of Senators Williams and Sparkman).

66. 12 C.F.R. $\S 225$ (1977). Prior to December 1, 1971, Regulation Y and interpretations thereunder were designated Part 222, 12 C.F.R. $\$ 222$ (1970).

67. 12 C.F.R. $\$ 225.4(a)(4)$ (1977). The first proposal stated only that a bank holding company could retain or acquire a company engaged in acting as a fiduciary. 36 Fed. Reg. 1430, 1431 (1971). As adopted, activity (4) was expanded to include "performing or carrying on any one or more of the functions or activities that may be performed or carried on by a trust company (including activities of a fiduciary, agency, or custodian nature) . . . "36 Fed. Reg. 10777 (1971).

68. 12 C.F.R. $\$ 225.4(a)(5)$ (1977). As initially proposed, a bank holding company could retain or acquire a company engaged "in acting as investment or financial adviser, including for a mortgage investment trust or a real estate investment trust." 36 Fed. Reg. 1430, 1431 (1971). When the rules respecting other permissible nonbanking activities were adopted in June 1971 in Federal Reserve Board Regulation $Y$, activity (5) read very much as proposed. Id. 10777.

69. 12 U.S.C. \$ 1843(c)(8) (1970). Under this statutory provision, the Federal Reserve Board is required to consider, in determining whether a particular activity is so closely related, whether performance of the activity by a subsidiary of a holding company

can reasonably be expected to produce benefits to the public, such as greater convenience, increased competition, or gains in efficiency, that outweigh possible adverse effects, such as undue concentration of resources, decreased or unfair competition, Id. conflicts of interests, or unsound banking practices.

70. In August 1971, the Federal Reserve Board issued a notice proposing that the list of permissible non-banking activities in Regulation Y, 12 C.F.R. $\$ 225.4$ (a) (1970), be amended to include "serving as investment adviser to an investment company registered under the Investment Company Act of 1940." 36 Fed. Reg. 16695 (1971). In this notice, the Federal Reserve Board stated that it had considered the Supreme Court's decision in Camp, but had concluded that its authority respecting permitting bank holding companies to sponsor open- or closed-end investment companies had not been affected.

A second notice was published by the Federal Reserve Board in October, 1971 which noted that the ICI had submitted a memorandum of law raising Glass-Steagall Act issues and requesting a hearing. 36 Fed. Reg. 20779 (1971).

71. See Memorandum of Investment Company Institute on Federal Reserve Board Proposal to Permit Bank Holding Companies or Their Subsidiaries to Act as Investment Advisers to Registered Investment Companies (Sept. 23, 1971); Supplemental Memorandum of Investment Company Institute (Oct. 22, 1971); Memorandum of the Department of Justice re Proposed 
of the arguments in opposition, it chose to adopt the proposal and address the potential problems by interpretation thereof. ${ }^{72}$ The proper path thus delineated, a number of bank holding companies promptly created nonbank investment advisory subsidiaries ${ }^{73}$ and began serving as investment advisers to closed-end funds. ${ }^{74}$ In May 1974, the ICI sued the Federal Reserve Board, contending that the relevant provisions of Regulation $\mathrm{Y}$ permitting bank holding companies to engage in investment activities were in violation of the Glass-Steagall Act. ${ }^{75}$

Amendment of Section 222.4(a)(5) of Regulation Y: Serving as Investment Advisor to an Investment Company Registered Under the Investment Company Act of 1940 (Sept. 24, 1971).

72. 12 C.F.R. $\S 225.4(\mathrm{a})(5)(\mathrm{ii)}$ (1977), adopted in 37 Fed. Reg. 1463 (1972); 12 C.F.R. § 225.125 (I977), adopted in 37 Fed. Reg. 1464 (1972). As finally adopted, activity (5) was modified slightly to refer to "serving as investment adviser, as defined in $\$ 2(a)(20)$ of the Investment Company Act of 1940 [15 U.S.C. $\$ 80 \mathrm{a}-2(\mathrm{a})(20)$ (1970)]."”

73. See Fiske, The Banks Fight Back, 6 InST. Inv. 41 (Apr. 1972); Bankers Trust Announces Plans to Set Up Investment Advisory Unit in Florida, Wall St. J., Sept. 25, 1972, at 28, col. 4; Advertisement by Bank America Corp. for BA Investment Management Corp., Wall St. J., Oct. 2, 1972, at 17, col. 4; Citicorp Plans Unit to Aid Investors in San Francisco, Wall St. J., Dec. 21,1972 , at 10 , col. 4 . One of the new nonbank investment advisory subsidiaries was Chase Investors Management Corporation New York, which by application in June 1972 requested the SEC to grant it an exemptive order under section 202(a)(I1)(F) of Investment Advisers Act of 1940. Chase Investors Management Corp. New York, SEC Adm. Proc. File No. 3-3859 (Letter from Milbank, Tweed, Hadley \& McCloy to SEC (June 8, 1972)); SEC Investment Advisers Act Release Nos. 333 (Aug. 21, 1972) (notice of application), 342 (Oct. 17, 1972) (order for hearing) and 348 (Nov. 14, 1972) (order discontinuing hearing upon withdrawal of application). See Heinemann, Chase Bank Asks SEC to Exempt New Subsidiary, N.Y. Times, Sept. 21, 1972, at 67, col. 4 .

74. By December 1972, there were at least nineteen investment companies which were sponsored, organized and advised by banks or subsidiaries of bank holding companies, of which sixteen were closed-end and three were open-end. Memorandum of Investment Company Institute re Petition for Reconsideration and Rescission of Section 225.4(a)(5)(ii) of Regulation Y, 5-6 n.1 (Dec. 12, 1973). The sixteen closed-end funds had at that point registered, or commenced efforts to register, $\$ 1$ billion in securities under the Securities Act of 1933, and at least eleven had filed intentions to apply for a listing of their securities on the New York Stock Exchange. Id. 7-8. Participation in the three open-end investment companies is limited to banks and other fiduciary institutions. Id. 6-7 n.2. Subsequently, one of the larger closed-end funds received shareholder approval to convert into a no-load open-end investment company, $A d$ vance Investors Wins Holders' Nod for Mutual Fund Plan, Wall St. J., July 27, 1976, at 27, col. 3 , and another has sold its assets to a conventional mutual fund, SEC Investment Company Act Release No. 10,005 (Nov. 10, 1977), 13 SEC DoCKET 727 (1977) (order declaring applicant has ceased to be an investment company); Peachtree Equity's Holders Clear Buying of Assets by Bullock, Wall St. J., April I8, 1977, at 3, col. 2.

75. Investment Co. Inst. v. Board of Governors of the Fed. Res. Sys., 398 F. Supp. 725 (D.D.C. 1975) (dismissed for lack of subject matter jurisdiction), aff'd, 551 F.2d 1270 (D.C. Cir. 1977) (Federal Reserve Board action could have been challenged through timely petition in court of appeals; suggest re-petition of Federal Reserve Board). Prior to filing its complaint, the ICI petitioned for reconsideration and rescission of section 225.4(a)(5)(ii) of Regulation $Y$, Memorandum of Investment Company Institute re Petition for Reconsideration and Rescission of Section 225.4(a)(5)(ii) of Regulation Y (Dec. 12, 1973), which was rejected by the Board as without merit. Letter from Theodore E. Allison, Assistant Secretary of the Board of Governors, Federal Reserve System to G. Duane Vieth, Arnold \& Porter (Mar. 8, 1974), reprinted in [1973-1974 Transfer Binder] FED. SEC. L. REP. (CCH) \ 79,707. 


\section{Statutory Interpretive Analysis.}

A bank-sponsored investment management service which involves creation of a separate entity as the issuer of securities is subject to registration under the Securities Act of 1933 and the Investment Company Act, absent an exemption. ${ }^{76}$ Where a bank also acts as intermediary between investors and the separate fund, the underwriting function will be prohibited by the Glass-Steagall Act. ${ }^{77}$ It is not yet clear whether, if an unrelated broker-dealer serves as underwriter, the nature of the separate fund as a type of investment company is important to the Glass-Steagall Act prohibitions. ${ }^{78}$

76. Other than the situation discussed above regarding commingled managing agency accounts and closed-end investment companies, the only other litigated test of this proposition is the offering of mini-accounts. See text accompanying notes 101-16 infra.

77. This was clearly the holding of District Court Judge McGarraghy, Investment Co. Inst. v. Camp, 274 F.Supp. 624 (D.D.C. 1967), and is probably the better reading of Mr. Justice Stewart's majority opinion. Investment Co. Inst. v. Camp, 401 U.S. 617 (1971). However, the Supreme Court suggested in dictum, 401 U.S. at $625-26 \mathrm{n} .12$, that common trust funds-clearly a separate entity for purposes of the federal securities laws-were unquestionably proper activities under the Glass-Steagall Act. Moreover, the Comptroller of the Currency recently approved a request by a national bank to sell interests in a pool of mortgages originated by the bank's commercial department, similar in economic effect to sale of interests in a pool of mortgage-backed securities guaranteed by the Government National Mortgage Ass'n. Letter from Robert Bloom, Acting Comptroller of the Currency, to Leland S. Prussia, Executive VicePresident, Bank of America (Mar. 30, 1977), Fed. BANKING L. REP. (CCH) I 97,093. And the Federal Reserve Board staff has ruled in favor of allowing commercial banks to make direct, private placements of securities. Federal Staff Would Let Commercial Banks Make Private Placements of Securities, Wall St. J., June 20, 1977, at 6, col. 4. In a related event, however, serious questions were raised about investment by Bank of America in Reynolds Securities, Inc. Senators Proxmire, Williams Ask FRB to Explain Reynolds Securities Acquisitions, 371 Sec. Reg. \& L. ReP. (BNA) A-15 (Sept. 29, 1976); Burns Tells Williams and Proximre Bank of America Stake in Reynolds Is Not A Violation of Glass-Steagall, Wall St. Letter, Nov. 8, 1976, at 6, col. 2; FRB Defend's Role in Bank Acquisition of Interest in Reynolds Securities, FED. BANKING L. ReP. (CCH) No. 632, at 5 (Nov. 11, 1976).

78. Recasting the Camp case to isolate the way particular investment management services were discussed therein and ignoring for the moment the specific statutory language of the Glass-Steagall Act, one finds the Supreme Court characterizing traditional investment management services provided by banks-common trust funds, individual managing agency accounts, incidental brokerage services-as perfectly proper under the Glass-Steagall Act while characterizing the new service of commingled managing agency accounts as improper because it more obviously competes directly with investment banking, and thus raises the policy questions and possibilities of abuses which Congress addressed in the Glass-Steagall Act. However, the historical abuses related to use of the investment management function as an opportunity to invest money discriminatorily to the advantage of a bank's commercial customers would persist so long as a bank offers any investment management services. Schoenbaum, Bank Securities Activities and the Need to Separate Trust Departments from Large Commercial Banks, $10 \mathrm{U}$. MICH. J.L. REF. 1, 7-9 (1976). Since all investment management services necessarily involve that possible set of abuses, the key difference under the Glass-Steagall Act, as interpreted by the Supreme Court, between traditional trust department investment advisory activities and other investment management services must thus be the manner of offering advisory services.

Accordingly, to the extent the subjective strand of the Supreme Court opinion is controlling, all bank-sponsored investment management services offered generally to the public in a 


\section{Corporate Employee Benefit and Keogh Plan Trusts. ${ }^{79}$}

As with common trust funds and commingled managing agency accounts, controversy developed in the early 1960's over the exclusions from the federal securities laws for corporate employee benefit plan trusts and socalled Keogh plan trusts. ${ }^{80}$ Although qualified corporate employee benefit plan trusts had been excluded from the Investment Company Act by Congress in $1940^{81}$ there was no such exemption for them in the Securities Act of 1933 or the Securities Exchange Act. ${ }^{82}$ Moreover, the interpretive

manner meeting the traditional earmarks of a public offering subject to section 5 of the Securities Act of 1933, 15 U.S.C. $\$ 77$ e (1970), should then under the reasoning of the Court be found to violate the Glass-Steagall Act.

79. For a thorough, careful treatment by two men who were reportedly largely responsible for developing the SEC's positions in this area in the critical period from 1962-1964, see Mundheim \& Henderson, Applicability of the Federal Securities Laws to Pension and ProfitSharing Plans, 29 Law \& Contemp. Prob. 795 (1964). See also Brief of the Securities \& Exchange Commission at 27-34, Daniel v. International Bhd. of Teamsters, 561 F.2d 1223 (7th Cir. 1977), reprinted in [1976-1977 Transfer Binder] FED. SEC. L. REP. (CCH) I 95,846; Overman, Registration and Exemption from Registration of Employee Compensation Plans Under the Federal Securities Laws, 28 VAND. L. REv. 455 (1975).

80. Self-Employed Individuals Tax Retirement Act of 1962, Pub. L. No. 87-792, 76 Stat. 809 (codified in scattered sections of 18 U.S.C.).

81. From 1940 to 1970, section 3(c)(13) of the Investment Company Act provided the following exclusion from the definition of investment company: "any employees' stock bonus, pension, or profit-sharing trust which meets the conditions of Section 165 of the Internal Revenue Code,"; the phrase "as amended" was added after "Internal Revenue Code" in 1942. Revenue Act of 1942, ch. 619, 56 Stat. 798 (1942). The initial Investment Company Act bills drafted by the SEC did not contain any such exclusion. While the compromise bills drafted after five weeks of negotiation by the Commission and the investment company industry contained the foregoing exclusion (S. 4108 \& H.R. 10065, 76th Cong., 3d Sess. § 3(c)(13) (1940)), there is no discernible legislative history which explains its inclusion beyond mere statement of its existence. See S. REP. No. 1775, supra note 29, at 12-13; Hearings on S. 3580 Before a Subcomm. of the Senate Comm. on Banking \& Currency, supra note 29, at pt. 4; H.R. REP. No. 2639, supra note 29, at 12. See also Hearings on Proposed Amendments to the Securities Act of 1933 and to the Securities Exchange Act of 1934 Before the House Comm. on Interstate \& Foreign Commerce, 77th Cong., 1st Sess. $895-99$ (1942) (testimony of SEC Commissioner Purcell discussing SEC's 1941 legislative program and SEC understanding of corporate employee benefit plan exclusions); cf. Investment Company Act $\S 6(b), 15$ U.S.C. $\S$ 80a-6(b) (1970); SEC Investment Company Act Rule 6b-1, 17 C.F.R. \$270.6b-1 (1977) (statutory and rule exemption from the Act for employee's securities company).

82. In its 1941 legislative program, which was abandoned with the outbreak of World War II, the Commission had proposed two amendments to the Securities Act of 1933: (I) an exemption from the Act for regular corporate employee benefit plan trusts meeting very stringent investment, safekeeping, disclosure and reporting requirements, Hearings on Proposed Amendments to the Securities Act of 1933 and to the Securities and Exchange Act of 1934 Before the House Comm. on Interstate \& Foreign Commerce, supra note 81, at 908; and (2) power by rule to exempt regular corporate employee benefit plan trusts from section 5 of the Act, 15 U.S.C. \& 77e (1970), Hearings on Proposed Amendments to the Securities Act of 1933 and to the Securities and Exchange Act of 1934 Before the House Comm. on Interstate \& Foreign Commerce, supra note 8, at 907, 950. Also, the SEC opposed a bill proposed at the same hearings which would have exempted from the definition of security any employee 
theories developed historically by the Commission for determining when to assert the applicability of the disclosure requirements of the federal securities law in the pension trust fund area ${ }^{83}$ were severely tested by the methods proposed by the banking industry for marketing interests in Keogh plan collective investment trust funds. ${ }^{84}$

benefit plan qualified under section 165 because the then-conditions of section 165 were thought not sufficient to justify exemption from the Securities Act for all qualified plans, and to preserve applicability of the antifraud provision in section 17(a) of the Securities Act, 15 U.S.C. $\S 77 \mathrm{q}(\mathrm{a})$ (1970), Hearings on Proposed Amendments to the Securities Act of 1933 and to the Securities and Exchange Act of 1934 Before the House Comm. on Interstate \& Foreign Commerce, supra note 81 , at 919-20.

83. Where an employer's stock is the investment medium for an employee benefit plan trust, the Commission has long insisted that a registration statement be filed under the Securities Act of 1933. The legal authority for this position stems from a proposed revision in 1934 to the Securities Act of 1933 during the Senate floor debate on what would become the Securities Exchange Act to include in the nonpublic offering exemption "an offering made solely to employees of an issuer or of its affiliates in connection with a bona fide plan for the payment of extra compensation or stock investment plan for the exclusive benefit of such employees." 78 CONG. REC. 8708 (1934). The proposed revision was eliminated by the Conference Committee "on the ground that the participants in employees' stock-investment plans may be in as great need of the protection afforded by availability of information concerning the issuer for which they work as are most other members of the public." H.R. REP. No. 1838, 73d Cong., 2d Sess. 41 (1934). See SEC v. Ralston Purina Co., 346 U.S. 119 (1953).

Second, even where interests in a pension plan trust are viewed as securities, it could be argued that the prohibitions of section 5 of the Securities Act, 15 U.S.C. $\$ 77$ e (1970), would not apply because there would be no "sale" (as defined in section 2(3), 15 U.S.C. \& 77b(3) (1970)) "for value" because the pension plan trust was created and funded by the employer for the benefit of his employees as a gratuitous gift to them, or because the employee contributions to the pension plan trust were compulsory. For early Commission testimony and SEC staff opinions to this effect, see Hearings on Proposed Amendments to the Securities Act of 1933 and to the Securities and Exchange Act of 1934 Before the House Comm. on Interstate \& Foreign Commerce, supra note 81, at 896-97; Opinions of SEC Assistant General Counsel, [1941-1944 Transfer Binder] FED. SEC. L. REP. (CCH) II 75,195; Letter from SEC Division of Corporate

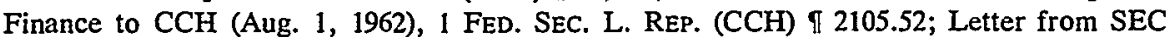
Division of Corporation Finance to CCH (May 12, 1953), 1 FED. SEC. L. REP. (CCH) I 2105.5. But see Daniel v. International Bhd. of Teamsters, 410 F.Supp. 541 (N.D. Ill. 1976) (interest in involuntary, noncontributory pension plan is sale of a security for value), aff'd, 561 F.2d 1223 (7th Cir. 1977).

84. One of the permissible funding techniques for Keogh plan trusts is deposit in collective investment trust funds of which a bank is trustee. I.R.C. $\$ 401$ (d); Treas. Reg. \$ 1.401-12 (1963).

Prior to 1955, the Federal Reserve Board in administering its Regulation $F$ had not permitted national banks to operate a collective investment trust fund for corporate employee benefit plans. 20 Fed. Reg. 3305 (1955). Such a collective investment trust fund would not be a common trust fund within the meaning of I.R.C. $\$ 584$ or Regulation F, but could otherwise achieve exemption from federal income taxation as a separate entity if used solely for employee benefit plan trusts qualified under I.R.C. $\S \S 401$ (a) and 501(a). Rev. Rul. 56-267, 1956-1 C.B. 206.

As to the need for master plan standardization, mass-merchandising and computerization to handle enough volume in Keogh plans to justify offering an investment management service for small accounts in direct competition with mutual funds, see, for example, Advertisement by the Chase Manhattan Bank, N.Y. Times, Dec. 7, 1962, at 29, col. 2, reprinted in Fascell 1963 Hearing 113; A Fork in the Road, Address by G.T. Lumpkin, Jr., Vice President, Wachovia 
The Commission took the position at congressional hearings in 1963 and 1964 that the proposed methods for offer and sale of interests in Keogh plan collective investment trust funds would involve a public offering of securities and would thus require registration under the Securities Act of 1933, but construed the qualified corporate employee benefit plan trusts exclusion in section 3(c)(13) of the Investment Company Act to include individual Keogh plan trusts as well as Keogh plan collective investment trust funds. ${ }^{85}$ With the inconclusive end of those hearings, ${ }^{86}$ the competitive pressure to attract potential Keogh plan customers, as well as the Commission's no-action position as to the applicability of the Investment Company Act to collective investment trust funds for any type of qualified pension plan, bankers were forced during the next six years to cope with the registration requirements of the Securities Act of 1933 as best they could. ${ }^{87}$

The final, conclusive round of legislative consideration of the status of corporate employee benefit plan trusts and Keogh plan collective investment trust funds began with the introduction in the 90th Congress of the SEC's mutual fund reform legislation. ${ }^{88}$ Amendments sponsored by Senator McIntyre proposed codifying the Commission's Investment Company Act interpretive position and formally exempting pension plan collective investment trust funds from the disclosure provisions of the Securities Act of 1933 and the Securities Exchange Act, but vesting jurisdiction as to disclosure for Keogh plan trusts with the three federal banking agencies. These amend-

Bank \& Trust Co., Before the 44th Mid-Winter Trust Conference, New York City (Feb. 5, 1963), reprinted in Fascell 1963 Hearing 114-20.

85. Fascell 1963 Hearing 7 (testimony of SEC Chairman Cary); see Mundheim \& Hendcrson, supra note 79, at 834-36. But see Fascell 1963 Hearing 37-38 (Memorandum, undated, of Comptroller of the Currency re Applicability of Securities Act of 1933 and Investment Company Act of 1940 to Common Trust Funds Operated by National Banks).

86. Bills drafted by the American Bankers Ass'n and introduced in the 88th Congress and 89 th Congress, discussed at notes $46,52-60$ supra, would have codified the Comptroller of the Currency's views as to the applicability of the federal securities laws to individual or collective investment trust funds for Keogh accounts, but were never reported out of committee after hearings were held.

87. With just the Securities Act of 1933 to deal with, however, it is understood that many banks proceeded to solicit Keogh plan customers for their employee benefit collective investment trust funds in reliance principally on the intrastate exemption in section $3(a)(11)$ of the Act, 15 U.S.C. \& 77c(a)(11) (1970). Mundheim \& Henderson, supra note 79, at 830 n.114.

88. S. 1659, 90th Cong., 1st Sess., 113 CoNG. REC. 11255 (1967); H.R. 9510 and H.R. 9511, 90th Cong., 1st Sess., 113 CoNG. Rec. 11347 (1967). See note 52 supra. In one of its last minor legislative recommendations, the Commission suggested that Investment Company Act section 3(c)(13) be amended to refer to I.R.C. § 401(a), as amended, but made no mention of providing parallel exemptions to Investment Company Act sections 3(c)(3) and 3(c)(13) in the Securities Act of 1933 or the Securities Exchange Act. Securities \& ExChange CoMm'N, Public Policy IMPLICATIONS OF INVESTMENT COMPANY GROWTH, supra note 52, at 342; S. 1659, 90th Cong., 1st Sess. § 3(b)(6), 113 CONG. REC. 11255 (1967). 
ments were in large part included in the bill reported out by the Senate, ${ }^{89}$ but the House failed to act. ${ }^{90}$ In the 91 st Congress, the several pension plan collective investment trust fund exemptions were retained, but the Keogh plan trust exemptive provisions on disclosure matters were modified in the bills passed by the Senate ${ }^{91}$ and the House ${ }^{92}$ to leave Keogh plans fully subject to the disclosure provisions of the federal securities laws. The Commission was given rule-making authority to exempt Keogh plans from the disclosure requirements to the extent necessary or appropriate in the public interest and consistent with the protection of investors. The provisions dealing with pension plan trusts survived the Conference Committee in November 1970 in this posture ${ }^{93}$ and became law in December. ${ }^{94}$ To date, the Commission has not adopted any rules respecting Keogh plan trusts under the authority granted it in section 3(a)(2) of the Securities Act of 1933.

The employee benefit plan provisions in section 3(c)(11) of the Investment Company Act of 1940 and section 3(a)(2) of the Securities Act of $1933^{95}$ should, then, be read to exclude from the operative registration and

89. S. 3724, 90th Cong., 2d Sess., 114 CoNG. REC. 23544 (1968); S. ReP. No. 1351, 90th Cong., 2d Sess. 9-11 (1968); See Hearing on Amendment No. 438 to S. 1659 Before the Senate Comm. on Banking \& Currency, supra note 4, pt. 3 at 1211-1353.

90. For House discussion of these amendments, see Hearings on H.R. 14742 Before the Subcomm. on Commerce \& Finance of the House Comm. on Interstate \& Foreign Commerce, supra note 41.

91. S. 2224, 91 st Cong., 1st Sess. \$\$ 3(b)(6), 12(d), 27(b), 28(a), 28(c), 115 CONG. REC. 13700 (1969); S. REP. No. 184, supra note 56, at 22-28; see Hearings on S. 34 and S. 296 Before the Senate Comm. on Banking \& Currency, supra note 55.

92. H.R. 17333, 91st Cong., 2d Sess. §§ 3(b)(5), 12(d), 27(b), 28(a), 28(c), 116 CoNG. REC. 33287 (1970); H.R. REP. No. 1382, 18, 31-32, 43-45; see Hearings on H.R. 11995, S. 2224, H.R. 13754, and H.R. 14737 Before the Subcomm. on Commerce \& Finance of the House Comm. on Interstate \& Foreign Commerce, 91st Cong., 1st Sess., pts. 1 \& 2 (1969).

Interestingly, one critical suggestion regarding the pension plan provisions in section 3(a)(2) of the Securities Act of 1933 came from persons quite distant from the collective investment management controversy. The General Counsel for Sperry Rand Corp. correctly noted that section 3(a)(2) as it would be amended by H.R. 11995 did not explicitly exempt interests in a single employee benefit plan, as distinguished from collective investment arrangements, and proposed language which would have made section 3(a)(2) parallel the two-clause approach in section 3(c)(13) (now renumbered to be section 3(c)(11)) as it would be amended by H.R. 11995. Letter from Standard Dunn, General Counsel, Sperry Rand Corp., to Representative Moss, Chairman, Subcomm. on Commerce \& Finance of House Comm. on Interstate \& Foreign Commerce (Nov. 7, 1969), reprinted in id., pt. 2, at 929-30.

93. H.R. REP. No. 1631, supra note 60.

94. Investment Company Amendments Act of 1970, Pub. L. No. 91-547, 84 Stat. 1413 (codified in scattered sections of 15 U.S.C.).

95. It is difficult to understand why the provisions in Securities Exchange Act §§ 3(a)(12) and $12(\mathrm{~g})(2)(\mathrm{H}), 15$ U.S.C. $\$ \S 78 \mathrm{c}(\mathrm{a})(12), 78 \mathrm{l}(\mathrm{g})(2)(\mathrm{H})(1970)$, although clearly intended by Congress to parallel Investment Company Act $\S 3(\mathrm{c})(3)$ and 3(c)(11), 15 U.S.C. $\$ \S 80 \mathrm{a}-3(\mathrm{c})(3)$, 3(c)(11) (1970), do not conform strictly to section 3(c)(3) or section 3(c)(11) in drafting technique or substance. Included in neither sections $3(\mathrm{a})(12)$ nor $12(\mathrm{~g})(2)(\mathrm{H})$ is an explicit exemption for 
regulatory provisions of those Acts all individual corporate ${ }^{96}$ and Keogh employee benefit plan trusts which meet the requirements for qualification under section 401 of the Internal Revenue Code of 1954, and all corporate and Keogh employee benefit plan trusts (also so qualified) commingled in a collective trust fund maintained by $a b$ ank $^{97}$ consisting solely of the assets of

interests in individual corporate employee benefit plan trusts. Moreover, the tortured drafting of section $12(\mathrm{~g})(2)(\mathrm{H})$ fails clearly to include any common trust fund which does not (since it cannot) issue interests in connection with a qualified employee benefit plan trust, although sections (a) and (b) of SEC Securities Exchange Act Rule 12h-2 exclude from section 12(g) certain individual corporate (and perhaps Keogh) employee benefit plan trusts and common trust funds. 17 C.F.R. $\S \S 240.12 \mathrm{~h}-2$ (a), (b) (1977). It would seem desirable for section $12(\mathrm{~g})(2)(\mathrm{H})$ to be redrafted and legislatively amended to conform strictly to Investment Company Act $\S \S 3(c)(3)$ and 3(c)(11).

96. Because of the last-minute inclusion by the Conference Committee of the phrase "single or" in section 3(a)(2), as discussed in note 92 supra, there has been (not unnaturally) a great deal of uncertainty and confusion based on the syntactical expression which was clumsily used to express legislative purpose. See, e.g., Friedman, The Securities Act of 1933 and Employee Compensation Plans, in Sixth ANNUAL Institute on SeCURITIEs Regulation 373, 385 (R. Mundheim, A. Fleischer, Jr., J. Schupper, J. Jewett \& J. Thomson eds. 1975). The legislative history of the employee benefit plan trust exemptions unequivocally suggests that Congress intended merely to codify the Commission's administrative interpretations of old section 3(c)(13), which until 1970 excluded just individual corporate employee benefit plan trusts. In adding parallel provisions respecting collective investment trust funds to section 3(a)(2) and in adding the second clause to new section 3(c)(11), Congress omitted until the last moment to provide in section $3(\mathrm{a})(2)$ a provision paralleling the first clause in new section 3 (c)(11). The phrase "single or" must then be read to exempt any qualified individual corporate employee benefit plan, no matter by whom it is maintained. See Letter from SEC Division of Corporate Finance to Gilbert Associates, Inc.; GAI-Tronics Corp. (Oct. 31, 1977), [Current] FED. SEC. L. REP. (CCH) I 81,406 (individual corporate employee benefit plan trust administered by a bank may have an outside investment adviser; no-action given under section 3(a)(2) and first clause of section 3(c)(11)).

A not unrelated question is what is an "individual" corporate employee benefit plan trust in the context of industry-wide union-negotiated collective bargaining arrangements or conglomerate-wide uniform plans administered through one unit of the conglomerate. The SEC staff generally believes both of these hypothetical situations fall within the first clause of Investment Company Act $\S 3(\mathrm{c})(11)$, but prefers to approach each situation individually on a noaction letter basis. Letter from SEC Division of Investment Management Regulation to Gibson, Dunn \& Crutcher re Bank Trustee Pension and Profit-Sharing Plans (Mar. 18, 1974), [19731974 Transfer Binder] FED. SEC. L. REP. (CCH) I 79,768.

97. The issue here is whether a bank would be deemed to "maintain" an employee benefit plan collective trust fund described in the second clause of Investment Company Act $\$ 3$ (c)(11), 15 U.S.C. $\$ 80 \mathrm{a}-3(\mathrm{c})(11)(1970)$, if it permitted someone else (typically, a broker-dealer or investment adviser) to provide all investment management while the bank simply acted as mere custodian. The phrase was borrowed intact from Investment Company Act § 3(c)(3), 15 U.S.C. $\S 80 \mathrm{a}-3(\mathrm{c})(3)(1970)$, where it has always been interpreted to mean full fiduciary service and responsibility. Thus, "maintained by a bank" has been interpreted in the context of section $3(c)(11)$ to mean that a bank must retain significant investment management responsibilities and custodianship of the fund's portfolio. See, e.g., Letter from SEC Division of Corporate Finance to Sterling National Bank \& Trust Co. of New York (Feb. 10, 1976), [1975-1976 Transfer Binder] FED. SEC. L. REP. (CCH) I 80,433; Letter from SEC Division of Investment Management Regulation to Gibson, Dunn \& Crutcher re Bank Trustee Pensions and Profit-Sharing Plans (Mar. 18, 1974), [1973-1974 Transfer Binder] FED. SEC. L. REP. (CCH) I 79,768; Letter 
such trusts. ${ }^{98}$ The offering of interests in individual Keogh plan trusts and those corporate employee benefit plan trusts which are funded with the employer's securities are, however, still subject to the registration requirements of section 5 of the Securities Act of 1933, unless an exemption is available. ${ }^{99}$ All other employee benefit plan trusts are subject to the registration and regulatory provisions of the Securities Act of 1933 and the Investment Company Act, ${ }^{100}$ and the purchase or sale of interests in all employee

from SEC Division of Corporate Regulation to Bank of America (Dec. 8, 1971), [1971-1972 Transfer Binder] FED. SEC. L. REP. (CCH) ๆ 78,614.

98. A third source of controversy has been the "solely" condition in the second clause of Investment Company Act $\S 3(c)(11), 15$ U.S.C. \& 80a-3(c)(11) (1970), and the "exclusively" condition in the exclusion for common trust funds in section 3(c)(3), 15 U.S.C. § 80a-3(c)(3) (1970). The issue is usually raised by banks which wish to commingle individual corporate employee benefit plan trusts with their common trust funds on the theory that they are acting as trustees in both instances-a position supported by the Comptroller of the Currency's Regulation 9, 12 C.F.R. $\$ 9.18(\mathrm{~b})(2)$ (1977), but not in the legal history of common trust funds or collective investment funds.

The word "solely" in the second clause of section 3(c)(11) was used to restrict participation in the collective investment trust fund to qualified individual employee benefit plan trusts, the only arrangement where the Internal Revenue Service would agree that the collective investment trust fund could share the exemption from federal income taxation that the underlying trusts enjoyed. See note 84 supra. Such a collective investment trust fund was not deemed to be a common trust fund by the Federal Reserve Board or the Internal Revenue Service. Id. The word "exclusively" in section 3(c)(3) was intended to exclude from participation in common trust funds any trust or other fiduciary relationship outside traditional trust department bona fide fiduciary capacities which amounted to use of the vehicle for direct investment by individual members of the public. Individual corporate employee benefit plan trusts therefore could not be commingled with a common trust fund without jeopardizing the common trust fund's right to rely on section 3(c)(3) and exclusion from the Investment Company Act. See Letter from SEC Division of Investment Management Regulation to National Boulevard Bank of Chicago (Feb. 20, 1974).

99. Of course, some employee benefit plan arrangements may not even involve the offer or sale of a separate security, the touchstone of the federal securities laws. $C f$. Letter from SEC Division of Corporation Finance to Investment Company Institute (Sept. 20, 1974), [1974-1975 Transfer Binder] FED. SEC. L. REP. (CCH) ๆ 80,018 (no separate registration statement required for tax exempt pension plans funded solely by specific mutual fund shares where appropriate disclosure is made in the mutual fund prospectus).

100. In this regard, questions have been raised about the status of collective investment funds for individual retirement accounts, a category of pension plans recently authorized by section 408 of the Internal Revenue Code for employed persons otherwise not covered by corporate employee benefit plans. The SEC staff twice refused to take a no-action position with respect, inter alia, to the availability of section $3(\mathrm{c})(11)$ to a collective investment trust fund of IRAs because of the proposed method of merchandising and the fact that-unlike old section 3(c)(13), and the 1963 interpretive situation with Keogh plans-IRAs are authorized under section 408, not section 401, of the Internal Revenue Code. Letters from SEC Division of Investment Management Regulation to Mayer, Brown \& Platt re Continental Illinois National Bank \& Trust Co. of Chicago (Feb. 28, 1975 \& Nov. 20, 1975), [1975-1976 Transfer Binder] FED. SEC. L. REP. (CCH) I 80,411. The bank filed an application, since withdrawn, under Investment Company Act $\S 6(c), 15$ U.S.C. § 80a-6(c) (1970), requesting complete exemption from all provisions of the Investment Company Act. Continental Individual Retirement Trust Co. of Chicago, Application for an Order of Exemption pursuant to section 6(c) of the Investment Company Act of 1940, Application No. 812-3961 (May 27, 1976, filed June 1, 1976); 
benefit plan trusts themselves (and in all collective investment trusts for such plan trusts) would, of course, be subject to the general antifraud provisions of section 17(a) of the Securities Act, and section 10(b) and rule $10 \mathrm{~b}-5$ of the Securities Exchange Act.

\section{Mini-Accounts. ${ }^{101}$}

Beginning on October 1, 1967, First National City Bank and Merrill Lynch, Pierce, Fenner \& Smith, Inc. began aggressively promoting the bank's Special Investment Advisory Service (SIAS). ${ }^{102}$ SIAS involved an investor executing a limited power of attorney giving Citibank investment discretion and authorizing Merrill Lynch to accept instructions from Citibank. ${ }^{103}$ In February 1970, in seeking dismissal of injunctive proceedings brought against them by the SEC alleging that the offering of SIAS violated the Investment Company Act and Securities Act of 1933, Citibank and Merrill Lynch agreed to cease offering SIAS but to offer instead a nondiscretionary investment advisory service with execution of brokerage transactions available through any broker-dealer selected from a list of at least three provided by Citibank. ${ }^{104}$

Because of uncertainty caused by the SIAS case, in October 1972 former SEC Chairman Casey appointed an Advisory Committee on Investment Management Services for Individual Investors to assist the Commission in developing clearer policies and guidelines with respect to the offer-

SEC Investment Company Act Release No. 9462, 41 Fed. Reg. 44239 (1976); SEC Investment Company Act Release No. 9611 (Jan. 17, 1977), 11 SEC. DoCKET 1535 (1977) (order permitting withdrawal of application).

101. See generally Bines, Regulating Discretionary Management: Broker-Dealers as Catalysts for Reform, 16 B.C. IND. \& CoMm. L. REv. 347 (1975); Rosenblat \& Lybecker 666-73; Comment, Small Investment Advisory Services: Reclassification to Aid the Small Investor, 5 CONN. L. REv. 639 (1973).

102. SEC v. First Nat'l City Bank, SEC Litigation Release No. 4534, at 2 (Feb. 6, 1970), [1969-1970 Transfer Binder] FED. SEC. L. REP. (CCH) I 92,592.

103. Additionally, Citibank required a customer to have a minimum account of $\$ 25,000$, to authorize the bank to invest in different securities in a manner designed to produce long-term capital growth or income, and to permit the account to be handled as a normal brokerage account providing usual advices and confirmations by the broker-dealer. Merrill Lynch acted as custodian for the securities and cash in the SIAS accounts, and was exclusive broker for executing transactions. The SEC complaint also alleged that, after the initial investments were made, all decisions by Citibank to buy or sell a security were generally applied uniformly to all persons' accounts sorted by investment objective even though Citibank's advertising stated that Citibank would give each SIAS investor the same individualized, personalized attention and supervision as was received by customers of its regular investment advisory service designed for a minimum account of $\$ 200,000$. Id .

104. Id. For a contemporaneous discussion of the SIAS case, see Mostoff, The SEC, 17(d), and Incentive Compensation, in Institutional Investors in a Changing ECONOMY 317, 326 (M. Cohen \& K. Bialkin eds. 1970) (then Associate Director of SEC Division of Corporate Regulation). 
ing of these so-called mini-accounts. ${ }^{105}$ After three months of deliberation, ${ }^{106}$ the Advisory Committee submitted its report ${ }^{107}$ and made six major recommendations: ${ }^{108}$ the Investment Company Act should not be applicable to a mini-account service unless there is a pooling of clients' accounts; ${ }^{109}$ the Securities Act of 1933 should not be applicable if the offeror of a miniaccount service furnishes individualized service or does not have discretion to execute portfolio transactions; ${ }^{110}$ the Commission should promulgate guidelines for determining the applicability of the Investment Company Act and Securities Act; persons offering a mini-account service should give prospective clients a written disclosure statement containing material information to aid them in determining whether to retain the services of a particular firm; ${ }^{111}$ the Commission should adopt rules under the Investment

105. SEC Investment Advisers Act Release No. 341 (Oct. 12, 1972). See also Where Are We Going?, Address by SEC Chairman Casey before the Economic Club of Detroit (Sept. 18, 1972).

106. SEC Investment Advisers Act Release No. 344 (Oct. 27, 1972), [1972-1973 Transfer Binder] FED. SEC. L. REP. (CCH) I 79,066 (Memorandum of objectives issued for public comment).

107. ADVisory COMMITTEE REPORT 6-15. For subsequent discussions of the Advisory Committee Report by two of its eight members, see Everdell, Individual Advisory Accounts and the Registration Requirements, in FIFTH ANNUAL INSTITUTE ON SECURITIES REGULATION 163 (R. Mundheim, A. Fleischer, Jr., \& J. Schupper eds. 1974) (outside counsel for First National City Bank); Rosenblat, Mini-Accounts, in THE SEC SPEAKS AGAIN 87 (A. Sommer, Jr. \& A. Levenson eds. 1973) (then Chief Counsel, SEC Division of Investment Management Regulation).

108. The Advisory Committee Report made twenty-four separate recommendations, many of which emanated from concerns with specific conflicts of interest, from which the six major recommendations were drawn. ADVISORY COMMITTEE REPORT 42 (fee-splitting), 42-51 (relationships with broker-dealers), 54-55 (use of inside information).

109. The Advisory Committee, in considering the applicability of the Investment Company Act to mini-accounts, placed great emphasis on the differences between a mini-account client and a mutual fund shareholder: direct ownership of specified securities rather than an undivided interest in a changing portfolio of securities. ADVISORY COMMITTEE REPORT 20-22. The Advisory Committee also departed from the Commission's historical reliance on the significance of "overlapping" investment advice. See, e.g., Everdell, supra note 107, at 169-70 (remarks of Stanley Sporkin, Director, SEC Division of Enforcement); Comment, supra note 101 , at $664-69,669-76$. Thus, the Advisory Committee rejected the existing regulatory framework of the Investment Company Act in favor of promulgating rules and guidelines under the Investment Advisers Act. ADvisory COMMITTEE RePORT 22-23.

110. ADVISORY COMMITTEE REPORT 23-25. If the mini-account service were sufficiently individualized, the Advisory Committee contended that the conclusion that no public offering was involved would be a logical extension of the private offering exemption, 15 U.S.C. $\$ 77 d(2)$ (1970). ADVISORY COMMITTEE REPORT 24. But see Everdell, supra note 107, at 176 (remarks of William Everdell); Comment, supra note 101, at 657-64. Moreover, the Commission recently imposed sanctions upon a registered investment adviser whose representations regarding its "individualized" mini-account service were found to be untrue and misleading. Chase Investment Services of Boston, Inc., SEC Investment Advisers Act Release No. 449 (Mar. 28, 1975), 6 SeC Docket 587 (1975); Wall St. J., Apr. 1, 1975, at 22, col. 3.

111. See SEC Investment Advisers Act Release No. 442 (Mar. 5, 1975), 40 Fed. Reg. 11897 (1975) (proposed rule 206(4)-4 requiring preparation and dissemination of a written disclosure 
Advisers Act covering conflicts of interest and other abuses in connection with operation of mini-account services; ${ }^{112}$ and the Commission should establish standards for professional qualifications and financial responsibility of investment advisers, and a system of self-regulation of investment advisers. ${ }^{113}$ The SEC has not yet formally responded to the Advisory Committee Report. ${ }^{114}$

statement); SEC Investment Advisers Act Release No. 601 (July 21, 1977), [Current] FED. SEC. L. REP. (CCH) I 81,253 (reproposed as rule 204-4). For discussions of proposed rule 206(4)-4, see Fleischer, Forcing Advisers to Open Up, INST. INv. 95 (May 1975); Lybecker, Advisers Act Proposals, 8 REv. SEC. REg. 916, 917 (1975); Zero Minus Sixteen and Counting, Address by SEC Commissioner Evans Before the Security Traders Ass'n of Connecticut, Hartford (Apr. 15, 1975).

112. The term "investment adviser" is defined broadly in section 202(a)(11) of the Investment Advisers Act, 15 U.S.C. $\S 80 \mathrm{~b}-2$ (a)(11) (1970), but clause (A) excludes from the definition of investment adviser "a bank, or any bank holding company as defined in the Bank Holding Company Act of 1956 which is not an investment company." The term "bank" is defined in section 202(a)(2), 15 U.S.C. $\$ 80 \mathrm{~b}-2$ (a)(2) (1970), to mean national banks, member banks of the Federal Reserve System and state-chartered banks and trust companies. Nevertheless, the Advisory Committce recommended that banks, although not generally subject to the Investment Advisers Act, should voluntarily follow their Report's guidelines as a "safe harbor" from attack regardìng non-registration under the Investment Company Act and Securities Act of 1933. ADVISORY COMMITTEE REPORT 59-62.

113. The Investment Advisers Act does not presently contain statutory provisions parallel to those in the Securities Exchange Act which would authorize the Commission to: (1) establish standards for classifying investment advisers, and requiring persons in any class to comply with specified standards of training; (2) adopt rules relating to financial responsibility and related practices; or (3) register any association of investment advisers dedicated to self-regulation, or adopt rules governing principles of trade and other professional matters for investment advisers who choose not to belong to a self-regulatory organization. Rosenblat \& Lybecker 665-66.

However, in December 1975 the SEC submitted a draft bill containing such provisions as amendments to the Investment Advisers Act [SEC Investment Advisers Act Release No. 491 (Dec. 15, 1975), [1975-1976 Transfer Binder] FED. SEC. L. REP. (CCH) I 80,341] which, with some modifications, was subsequently introduced in January, 1976 as S. 2849 by Senator Williams. The Investment Advisers Act Amendments of 1976, S. 2849, 94th Cong., 2d Sess. (1976). A companion bill was introduced in the House by Representative Staggers. H.R. 12981, 94th Cong., 2d Sess. (1976). Hearings were almost immediately held in the Senate, Hearings on S. 2849 Before the Subcomm. on Securities of the Senate Comm. on Banking, Housing \& Urban Affairs, 94th Cong., 2d Sess. (1976), and S. 2849 was favorably reported out of the full committee in May 1976 without significant modifications as to these aspects. S. REP. No. 910, 94th Cong., 2d Sess. (1976). For a discussion of the amendments made by the Securities Acts Amendments of 1975 and the changes which would have been made by enactment of S. 2849, see Lybecker, Advisers Act Amendments, 9 REv. SEC. REG. 919 (1976). S. 2849 was, however, never voted on by the full Senate; the companion House bill also died, and there is presently no support from the SEC for passage of the bill in the 95th Congress.

114. But see Commission Inquiry Concerning Bank-Sponsored Investment Services, SEC Investment Advisers Act Release No. 409, at 5-6 (Apr. 30, 1974), [1973-1974 Transfer Binder] FED. SEC. L. REP. (CCH) T 79,767; Address by SEC Chairman Garrett before the Investment Company Institute, Washington, D.C. (May 15, 1974), summarized in [1973-1974 Transfer Binder] FED. SEC. L. REP. (CCH) \ 79,791, discussed in Mutual Fund Managers Celebrate 50th Birthday, 253 SEc. Rzg. \& L. Rep. (BNA) A-11 to A-12 (May 22, 1974). For a discussion suggesting that small trust accounts are unprofitable, see Jansen, Bidding Goodbye to the Small Personal Trust, INST. INv. 81, 84-86 (June 1976). 
The SEC's present litigation posture ${ }^{115}$ regarding discretionary investment management arrangements for investments in conventional debt and equity securities ${ }^{116}$ where the clients do not receive highly individualized treatment would be to require registration under the Securities Act of 1933 and the Investment Company Act, even though the investors' assets are not physically pooled together. Where the investors receive highly individualized treatment, the Commission will not litigate any status questions unless there are strong indications of fraud, overreaching and the like. Finally, a non-discretionary investment management service would not be required to register under the Securities Act of 1933 or under the Investment Company Act if the service arrangements provide the investors with sufficient information to make their own, independent investment decisions.

\section{E. Reflections.}

In the 1930's and early 1940's when Congress legislated (or failed to address) the various exemptions and exclusions for bank-sponsored investment management services, it did so in the context of the stock market crash of 1929, massive bank failures and flamboyant excesses of bank security affiliates. Indeed, there may even have been a smug expectation that there would be minimal future problems because most of the extant services had been prohibited or thoroughly circumscribed in terms of that era's abuses. However, as new services were developed they were tested against the bright-line litmus tests of old exemptions and old congressional expectations-not empirically or philosophically, but narrowly in an adversary manner on a case-by-case basis with the decision in each instance effected by a heavy amount of selfish comparative economic and political views. The preceding legal histories and statutory interpretive analyses suggest that the result is a significantly illogical regulatory scheme, and fully substantiate a need to rethink the appropriate scope of exemptions for bank-sponsored investment management services from the federal securities laws. The question remains what the standard should be for reconciling the overlapping federal regulatory schemes. It seems clear, moreover, that it is no

115. It is understood that the SEC staff has not responded to requests for no-action letters or interpretive advice since the Advisory Committee Report was published, other than to note its existence and disclaim any responsibility (or present applicability) of the views expressed therein, pending a formal Commission response to the Report.

116. It is beyond the scope of this paper to capsulize generally the Commission's litigation position respecting discretionary investment management services for investment in commodities, gold and other types of real or personal property. Compare Applicability of the Securities Laws to Multi-Level Distributorships and Pyramid Sales Plans, SEC Securities Act Release No. 5211 (Nov. 30, 1971), 36 Fed. Reg. 23289 (1971), 1 FED. SEC. L. REP. (CCH) \1048; Offers and Sales of Condominiums or Units in a Real Estate Development, SEC Securities Act Release No. 5347 (Jan. 18, 1973), 38 Fed. Reg. 1735 (1973), 1 FED. SEC. L. REP. (CCH) I 1049, with No-Action Position Relating to Certain Offerings of Gold, SEC Securities Act Release No. 5552 (Dec. 26, 1974), [1974-1975 Transfer Binder] FED. SEC. L. REP. (CCH) I 80,037. 
longer legally sufficient or appropriate to defer conclusively to the historical serendipity of whatever type of regulation a particular financial institution is used to receiving; rather, the reconciling standard or focus in considering exemptions must be the investor protections which ought to exist, whoever is offering the investment management service.

\section{Comparative Regulation UNDER THE FEDERAL SECURITIES AND BANKING LAWS}

As was discussed above, some bank-sponsored investment management services must satisfy the full gamut of disclosure and regulatory requirements of the federal securities laws, and others are merely subject to the antifraud provisions. All bank-sponsored investment management services are, nevertheless, subject to the disclosure and regulatory requirements of the federal banking laws. While part or all of particular bank-sponsored investment management services have been excluded from the various federal securities laws, the foregoing brief legal histories suggest that Congress did so not because investor protections for bank service participants were found unimportant as a matter of public policy, but because somewhat impressionistic representations were repeatedly made that appropriate investor protections were (or were not) already provided under the federal banking laws. This section will compare the essential ${ }^{117}$ investor protection provisions of the federal securities and banking laws to provide a more fully articulated basis for determining whether the exclusions from the federal securities laws granted by Congress were too sparse or too extensive.

\section{A. Information Disseminated About the Service.}

Each bank-sponsored investment management service which involves the offering of a security and is subject to the disclosure ${ }^{18}$ and prospectus

117. Some would argue that statutory provisions such as those which make larceny, conversion or embezzlement of assets a federal crime, see, e.g., 15 U.S.C. \$ 80a-36 (1970) (investment company), 18 U.S.C. $\$ 656$ (1970) (member bank of Federal Reserve System), provide essential investor protections because of their usual deterrent effect; on the other hand, those types of statutory provisions are more in the nature of necessary housekeeping matters found in virtually every regulatory statute and will not be discussed further in the text. Similarly, both the Securities Investor Protection Act, 15 U.S.C. §§ 78aaa-lll (1970), and FDIC provide insurance in the event of insolvency, although the schemes are not entirely parallel in many particular respects; full explication of the differences is also beyond the scope of this Article. Moreover, although state statutory banking laws and statutory and judicial trust law are important, perhaps even substantially more important relatively speaking than state Blue Sky laws, it is beyond the scope of this Article to attempt also to integrate them fully into this treatment of federal securities and banking laws. For an economic analysis of the effectiveness of insolvency insurance which suggests that it has the least misallocative effects and provides the most certainty of investor protection, see Clark, The Soundess of Financial Intermediaries, 86 YALE L.J. 1, 86-100 (1976).

118. Sections 6,7 and 8 of the Securities Act of 1933,15 U.S.C. $\$ \S 77 \mathrm{f}, 77 \mathrm{~g}, 77 \mathrm{~h}(1970)$, permit a security to be registered by filing a registration statement, stipulate the necessary 
delivery provisions of section 5 of the Securities Act ${ }^{119}$ will be required to keep a detailed registration statement current. ${ }^{120}$ The statutory prospectus is the first written material which must be distributed by the investment management service to its participants when it offers and sells a security to them. Additionally, each such service which involves the offering of a security may be required under section 30 of the Investment Company Act ${ }^{121}$ or section 13 of the Securities Exchange Act ${ }^{122}$ to file periodically and

contents of the registration statement, and give the SEC authority to declare the registration statement effective. See SEC Regulation C, 17 C.F.R. §§ 230.400-.494 (1977). See generally 1 Loss 265-83; 4 id. 2333-40 (Supp. 1969). Schedule A to the Act, 15 U.S.C. § 77aa (1970), contains the detailed disclosure items for ordinary issuers filing on Forms S-1 or S-7, 17 C.F.R. $\S \S 239.11$, 239.26 (1977), 2 FED. SEC. L. REP. (CCH) II 7121-29, 7190-96A; services also registering under section 8 of the Investment Company Act, 15 U.S.C. $\$ 80 \mathrm{a}-8$ (1970), are permitted to file the required registration statement on Forms $S-4, S-5$, or S-6, 17 C.F.R. $\$ \S$ 239.14, .15, .16 (1977), in conjunction with the Investment Company Act registration Forms $N$ 8B-1 and N-8B-2. 17 C.F.R. $\S \S 274.11$, .12 (1977), 2 FED. SEC. L. REP. (CCH) I 7161-66, 717177A, 7181-87. For good discussions of the matters which must be disclosed in a registration statement filed under the Securities Act of 1933, see Demas, Accounting Problems Before and During Registration, in Going Public: Filing Problems 147-94 (A. Levenson ed. 1970); Friedman, Preparation of the Registration Statement, in GoIng Public: Filing Problems, supra, at 73-122; Heller, Disclosure Requirements Under Federal Securities Regulation, 16 Bus. LAW. 300 (1961); SEC Securities Act Release No. 4936 (Dec. 9, 1968), 1 FED. SEC. L. REP. (CCH) \ 3762-3813.

Section 11 of the Securities Act contains detailed provisions for civil liability stemming from a false or misleading registration statement. 15 U.S.C. $\$ 77 \mathrm{k}$ (1970). See Escott v. BarChris Constr. Co., 283 F.Supp. 643 (S.D.N.Y. 1968); 3 Loss 1721-42; 6 id. 3842-56 (Supp. 1969). See generally A.B.A. National Institute, The BarChris Case: Prospectus Liability, 24 Bus. LAw. 523 (1969); Folk, Civil Liabilities Under the Federal Securities Acts: The BarChris Case (pts. 12), 55 VA. L. REV. 1, 199 (1969).

119. 15 U.S.C. $\$ 77 \mathrm{e}(1970)$. Section 5 restricts publication of certain information prior to filing a registration statement ("gun jumping"), during the period it is being examined by the SEC staff ("waiting period"), and after it is declared effective ("post-effective period"). See Chris-Craft Indus., Inc. v. Bangor Punta Corp., 426 F.2d 569 (2d Cir. 1970), rev'd sub. nom. Piper v. Chris-Craft Indus., Inc., 430 U.S. 1 (1977); SEC Securities Act Release No. 5009 (Oct. 7, 1969), [1969-1970 Transfer Binder] FED. SEC. L. REP. (CCH) ๆ 77,744; 1 Loss 178-260; 4 id. 2298-2331 (Supp. 1969). Sections 12(1) and 12(2) of the Securities Act create express civil liability (rescission rights) for any person who (1) offers to sell a security in violation of section 5 , or (2) makes untrue or misleading statements of material facts in a prospectus or oral communications. 15 U.S.C. $\S 77 l(1)$, (2) (1970). See 3 Loss 1692-1712; 6 id. 3827-34 (Supp. 1969).

120. Prospectuses must be kept current if they are used for an extended period of time after the registration statement is declared effective. SEC Securities Act Rules 423, 424(c) and 427, 17 C.F.R. $\S 230.423, .424$ (c), .427 (1977). For open-end investment companies which are by their very nature constantly in registration, the Commission has prepared specific guidelines for updating prospectuses and making post-effective amendments to registration statements. See e.g., SEC Securities Act Release No. 5439 (Nov. 14, 1973), [1973-1974 Transfer Binder] FED. SEC. L. REP. (CCH) I 79,559; SEC Securities Act Release No. 5305 (Sept. 21, 1972), [1972-1973 Transfer Binder] FED. SEC. L. REP. (CCH) \ 78,998.

121. 15 U.S.C. $\S 80 \mathrm{a}-29(\mathrm{a})$, (b) (1970). Investment companies must file annual reports on Form N-1R, 4 FED. SEC. L. REP. (CCH) I 51,961-985, and quarterly reports on Form N-1Q, 4 FED. SEC. L. REP. (CCH) If 52,101-141. SEC Investment Company Act Rules 30a-1, 30a2(a) \& 30b1-1, 17 C.F.R. §§ 270.30a-1, .30a-2(a), .30b1-1 (1977). Moreover, section 30(d) 
distribute frequently to its participants financial and other information concerning operation of the service. Whether or not a particular service is subject to these prospectus delivery or continuous disclosure requirements, all bank services which involve the offering of a security are subject to the negative disclosure requirements ${ }^{123}$ of the antifraud provisions of section

requires investment companies to transmit to their shareholders semi-annual reports containing detailed financial information. 15 U.S.C. \& 80a-29(d) (1970); 17 C.F.R. \& 270.30d-1 (1977). Under new section 13(f) of the Securities Exchange Act, 15 U.S.C. \& 78m(f) (Supp. V 1975), "every institutional investment manager" will be required to file detailed quarterly reports of his equity security transactions and all securities holdings. The SEC has proposed a rule implementing new section 13(f). SEC Securities Exchange Act Release No. 13,396 (Mar. 22, 1977), [1976-1977 Transfer Binder] Fed. Sec. L. ReP. (CCH) I 81,023 (proposed rule 13f-1). See generally Note, The Institutional Investor Disclosure Act: An Analysis of the Consumer Benefits, 83 Y ALE L.J. 1271 (1974). See note 129 infra.

In addition to these mandatory disclosure requirements, if under state law an investment company must solicit proxies from its shareholders, section 20 of the Investment Company Act, 15 U.S.C. $\$ 80 \mathrm{a}-20$ (1970), regulates the proxy solicitation procedure, and rule 20a-1 thereunder, 17 C.F.R. $\$ 270.20 \mathrm{a}-1$ (1977), incorporates by reference the disclosure requirements of section 14 of the Securities Exchange Act. 15 U.S.C. $\$ 78$ n (1970); 17 C.F.R. $\$ \$ 240.14 a-1-14 a-12, .14 a-$ 101 (1977). See generally 2 Loss 857-930. See also 17 C.F.R. \$\$ 270.20a-2, 20a-3 (1977) (information pertaining to investment adviser and investment advisory contract, and to certain transactions).

Finally, section 31 of the Investment Company Act requires specific accounts and records be kept, 15 U.S.C. $\$ 80 \mathrm{a}-30$ (1970); 17 C.F.R. $\$ \$ 270.31 \mathrm{a}-1$ to $.31 \mathrm{a}-3$ (1977), and section 32 requires an investment company to retain independent public accountants selected at a shareholders' meeting. 15 U.S.C. $\$ 80 \mathrm{a}-31$ (1970); 17 C.F.R. $\$ \$ 270.32 \mathrm{a}-1$, .32a-2 (1977). Such books, accounts, and records are subject to inspection by the SEC staff. 15 U.S.C. $\$ 80 \mathrm{a}-30$ (b) (1970).

122. 15 U.S.C. $\$ 78 \mathrm{~m}$ (1970 \& Supp. V 1975). See generally 2 Loss 809-23; 5 id. 2774-96 (Supp. 1969); Mundheim, Selected Trends in Disclosure Requirements for Public Corporations, 3 SEC. REG. L.J. 3 (1975). Section 13 of the Securities Exchange Act is applicable to every issuer of a security which must register under section 12, 15 U.S.C. \& 781 (1970 \& Supp. V 1975), and section 12 itself requires submission of a detailed registration statement. SEC Securities Exchange Act Rules 12b-1 to 12b-7, 12b-10 to 12b-15, 12b-20 to 12b-25, $12 \mathrm{~b}-30$ to 12b$34,12 b-36,17$ C.F.R. \$§ $240.12 b-1$ to $.12 b-7, .12 b-10$ to $.12 b-15, .12 b-20$ to $.12 b-25, .12 b-30$ to $.12 \mathrm{~b}-34, .12 \mathrm{~b}-36$ (1977). Under section 13, a so-called section 12(g) company must prepare and submit annual reports (Securities Exchange Act rules 13a-1 to 13a-2), interim reports and quarterly reports (Securities Exchange Act rules 13a-10, 13a-13), and reports twenty days after the end of any month in which an extraordinary event occurs (Securities Exchange Act rule 13a11). 17 C.F.R. \$ $240.13 a-1$ to .13a-2, .13a-10 to .13a-11, .13a-13 (1977).

Finally, any person who acquires more than five percent of the equity securities of a section $12(\mathrm{~g})$ company must under section 13(d) file statements of beneficial ownership containing information about the purchaser and his intentions. SEC Securities Exchange Act rules 13d1 to 13d-7, Schedule 13D, 17 C.F.R. §§ 240.13d-1 to .13d-4, .13d-101 (1977). For recent proposed amendments to the section 13(d) rules, see SEC Securities Exchange Act Release No. 13,900 (Aug. 29, 1977), [Current] FED. SEC. L. REP. (CCH) I 81,297; SEC Securities Exchange Act Release No. 13,292 (Feb. 24, 1977), [1976-1977 Transfer Binder] FED. SEC. L. REP. (CCH) \& 80,981 .

123. Unlike the affirmative disclosure requirements of sections 5 to 7 of the Securities Exchange Act, 15 U.S.C. $\$ \$ 77 \mathrm{e}-77 \mathrm{~g}$ (1970), or section 13 of the Securities Exchange Act, 15 U.S.C. $\S 78 \mathrm{~m}$ (1970 \& Supp. V 1975) or section 30 of the Investment Company Act, 15 U.S.C. $\S$ $80 \mathrm{a}-29$ (1970), the several antifraud provisions, notes 124-25 infra, impose liability for the making of untrue statements of material facts or for failure to state material facts necessary to 
17(a) of the Securities Act ${ }^{124}$ and section 10(b) of the Securities Exchange Act. ${ }^{125}$ Finally, the SEC has proposed a far-reaching "brochure rule" which would require investment advisers to publish and deliver to prospective clients detailed disclosure about their business operations. ${ }^{126}$

Under the federal banking laws, banks are subject to examination by the federal bank regulatory agencies ${ }^{127}$ and are required additionally to file

render statements made not misleading. However, there are no informal checklists or official SEC guidelines or forms respecting the antifraud provisions which, if properly observed, would provide some assurance that the issuer has probably disclosed all material facts; rather, the issuer itself must determine which facts are material and disclose them. Many observers believe that much less information is disclosed by virtue of the implicit threat of the antifraud provisions than is disclosed through the major formal filing and disclosure requirements of the federal securities laws, although there is some controversy over whether the formal disclosure requirements do in fact produce useful information. See Kripke, The SEC, the Accountants, Some Myths and Some Realities, 45 N.Y.U.L. REv. 1151 (1970); Schneider, Nits, Grits, and Soft Information in SEC Filings, 121 U. PA. L. REV. 254 (1972).

124. 15 U.S.C. $\$ 77 q$ (1970 \& Supp. V 1975). Although there is no express provision creating civil liability under section 17 , other than the language of the section itself, federal courts have generally held there is an implied private right of action to enforce violations of the section. E.g., Crowell v. Pittsburgh \& Lake Erie R.R. Co., 373 F.Supp. 1303, 1310 (E.D. Pa. 1974). But see Globus v. Law Research Serv., Inc., 418 F.2d 126 (2d Cir. 1969), cert. denied, 397 U.S. 913 (1970); SEC v. Texas Gulf Sulphur Co., 401 F.2d 833, 867 (2d Cir.) (concurring opinion, Friendly, J.), cert. denied, 394 U.S. 976 (1968); 3 Loss 1785. In a major opinion limiting the scope of SEC Securities Exchange Act Rule 10b-5, 17 C.F.R. \$ 240.10b-5 (1977), Mr. Justice Rehnquist stated ominously in a footnote that the Supreme Court "express[ed], of course, no opinion on whether $\S 17(a)$ in light of the express civil remedies [in section 12] of the 1933 Act gives rise to an implied cause of action." Blue Chip Stamps v. Manor Drug Stores, 421 U.S. 723,734 n.6 (1975).

125. 15 U.S.C. $\$ 78 \mathrm{j}(1970)$. A series of recent court decisions are "must" reading, e.g., Ernst \& Ernst v. Hochfelder, 425 U.S. 185 (1976) ("scienter" requirement in aiding and abetting); Blue Chip Stamps v. Manor Drug Stores, 421 U.S. 723 (1975) (standing to sue; purchaser-seller requirement); Green v. Santa Fe Indus., Inc., 533 F.2d 1283 (2d Cir. 1976), rev'd, 430 U.S. 462 (1977) (no cause of action under rule 10b-5 for breaches of state law duties); Marshel v. AFW Fabric Corp., 533 F.2d 1277 (2d Cir. 1976) (breach of fiduciary duty of majority shareholders to minority in squeeze-out absent corporate business purpose). See generally A. BRomberg, Securities Law Fraud: SEC Rule 10b-5 (1977); Symposium, An InDepth Analysis of the Federal and State Roles in Regulating Corporate Management, 31 Bus. LAw. 869 (1976).

126. See Investment Advisers Act Release No. 442 (Mar. 5, 1975), [1974-1975 Transfer Binder] FED. SEC. L. REP. (CCH) ๆ 80,128 (proposed rule 206(4)-4); Investment Advisers Act Release No. 601 (July 21, 1977), [Current] FED. SEC. L. REP. (CCH) I 81,253 (reproposed as rule 204-4). For discussions of proposed rule 206(4)-4, see Fleischer, supra note 111, at 95; Lybecker, supra note 111, at 917; Schoeman, Subscription Advisers, Blue Sky Registration and the First Amendment, 33 Bus. LAw. 249 (1977).

127. 12 U.S.C. $\$ 481$ (1970) (Comptroller of the Currency); id. $\$ \$ 325,483$ (Federal Reserve Board); id. § 1817(a) (FDIC).

The Comptroller of the Currency's detailed examination instructions are found in COMPTROLLER'S EXAMINATION MANUAL and in the COMPTROLLER's HANDBOOK. The Comptroller of the Currency's Regulation 9 requires a national bank to keep fiduciary records separate and distinct from other records of the bank, and such fiduciary records must contain full information as well as all pending litigation to which it is a party relative to each account. 12 C.F.R. $\S$ 9.8 (1977). Finally, a committee of a bank's directors, not including any active officers of the 
financial statements periodically. ${ }^{128}$ The Comptroller of the Currency's Regulation 9 also requires trust departments to prepare annual financial reports ${ }^{129}$ which may be distributed to current or prospective participants, but there is nothing which must be distributed that approaches a prospectus in detail or rigor. ${ }^{130}$ As a collateral matter, advertising about a service which involves the issuance of a security is substantially constrained under the Securities Act during the time the security is being offered, ${ }^{131}$ while Regula-

bank, must make suitable audits of the trust department at least once a year and within fifteen months of the last such audit. Id. § 9.9. See also id. § 9.18(b)(5)(i) (annual audit of collective investment funds by auditors responsible only to the board of directors).

128. 12 U.S.C. \& 161 (1970) (Comptroller of the Currency; no less than four reports a year); id. §§ 248(a), 324 (Federal Reserve Board); id. § 1817(a) (FDIC). For the annual and quarterly reporting forms of the Comptroller of the Currency, the Federal Reserve Board and FDIC, see 12 C.F.R. $\S 11.4$ (1977) (Comptroller of the Currency); id. $\S \S 206.42-.44$ (Federal Reserve Board); id. §§ 304.1-.3, 335.4 (FDIC).

129. 12 C.F.R. $\$ \S 9.18$ (b)(5)(ii)-(iv) (1977). The annual financial report may contain descriptions of the collective investment fund's value on previous dates, as well as its income and disbursements, but no predictions or representations about future results can be made nor can the performance of common trust funds be compared with the investment performance of other funds not administered by the bank. 12 C.F.R. § 9.18(b)(5)(iii) (1977). Copies must be furnished or made available at no charge to participants, and may be furnished to prospective customers. Id. § 9.18(b)(5)(iv).

Additionally, quarterly reports must be submitted by a trust department containing information similar to that which may be required under new Securities Exchange Act $\S 13(f), 15$ U.S.C. $\$ 78 \mathrm{~m}$ (f) (Supp. V 1975); 12 C.F.R. \$§ 9.101-.104 (1977). For detailed discussions of the differences between this aspect of Regulation 9 and the bills in the 93d Congress which contained the institutional disclosure requirements embodied in new section 13(f), see Hearings on Corporate Disclosure Before the Subcomm. on Budgeting, Management and Expenditures and the Subcomm. on Intergovernmental Relations of the Senate Comm. on Government Operations, 93d Cong., 2d Sess., pt. 3, at 189-213 (1974) (testimony of author); Hearings on $S$. 2234 and S. 2683 Before Subcomm. on Securities of the Senate Comm. on Banking, Housing and Urban Affairs, 93d Cong., 2d Sess. (1974); Hearing on H.R. 10570 and H.R. 13986 Before the Subcomm. on Commerce and Finance of the House Comm. on Interstate and Foreign Commerce, 93d Cong., 2d Sess. (1974). For a provocative evaluation of preliminary data submitted under Regulation 9, see Schotland, Bank Trust Departments and Public Policy Today in House Comm. on Banking, Currency \& Housing, 94Th Cong., 2D Sess., Compendium of Papers PRepared for the FINE Study, House Comm. on Banking, Currency \& Housing, pt. 1, at 211 (Comm. Print 1976).

130. In addition to financial statements, an investment company prospectus must discuss investment objectives, personnel of the fund and its investment adviser, operation of an investment company, portfolio policy and turnover, leverage, short sales, diversification and concentration, restricted securities, the advisory contract, use of brokerage, redemption methods, conflicts of interest and pending legal proceedings. See Guidelines for Forms S-4 and S-5, SEC Investment Company Act Release No. 7220 (June 9, 1972), 2 FED. SEC. L. REP. (CCH) I 7178. Whether or not one believes this type of information should be distributed mandatorily, there can be no question that it involves much more complete disclosure than would be provided under Regulation 9. Under Regulation 9, a bank must prepare a plan describing the collective investment funds, including the manner in which it is to be operated, investment powers, general investment policy, allocation of income and expenses, withdrawal methods and method of valuation. 12 C.F.R. $\$ 9.18(b)(1)$ (1977). The plan must be furnished to any person, but only upon request. Id.

131. SEC Securities Act rules 134 and 135, 17 C.F.R. $\$ \S 230.134-135$ (1976). See Chris-Craft Indus., Inc. v. Bangor Punta Corp., 426 F.2d 569 (2d Cir. 1970), rev'd sub nom. Piper v. Chris- 
tion 9 limits publicity promoting the availability of fiduciary services of a bank to general promotion and distribution of the annual financial report. ${ }^{132}$

\section{B. Statutory and Other Implied Fiduciary Responsibilities.}

\section{Professional Qualifications and Financial Responsibility.}

Section 9 of the Investment Company Act prohibits persons convicted of or enjoined from committing certain types of misconduct from becoming any part of the investment company industry; ${ }^{133}$ sections 203(e) of the Investment Advisers Act ${ }^{134}$ and 15(b)(4) of the Securities Exchange Act ${ }^{135}$ similarly restrict persons wishing to register as investment advisers or broker-dealers. Further, persons registering as broker-dealers must pass examinations and comply with specified standards of training established by Commission rules ${ }^{136}$ or by the NASD. ${ }^{137}$ Moreover, the Commission has

Craft Indus., Inc., 430 U.S. 1 (1977); SEC Securities Act Release No. 5180 (Aug. 16, 1971), 1 FED. SEC. L. REP. (CCH) I 3056. Because open-end investment companies are by their very nature constantly in registration under the Securities Act of 1933, the Commission has permitted limited generic advertising by mutual funds. SEC Securities Act Rule 135A, 17 C.F.R. $\S$ 230.135a (1977). For indications that the SEC is considering more liberal treatment of investment company advertising, see SEC Investment Company Act Release No. 9931 (Sept. 14, 1977), 42 Fed. Reg. 47563 (1977) (announcment of re-examination of statement of policy relating to sales literature of investment companies); Hills Says '40 Act Revisions May Be Made; Singles Out Two Provisions Affecting Mutual Funds, 355 SEc. REg. \& L. REP. (BNA) A2 (June 2,1976 ) ("I could be easily persuaded that a perfectly good advertising rule would be one that does no more than prohibit fraud and ensure that all persons receive a prospectus before they invest').

132. 12 C.F.R. $\$ \S 9.18(b)(5)(i v)$, (v) (1977); COMPTROLLER'S EXAMINATION MANUAL 10I; Letters from Deputy Comptroller of the Currency for Trusts (Jan. 29, 1973 and Aug. 8, 1973), FED. BANKING L. REP. (CCH) \96, 355 (letters to unnamed bank officers regarding restrictions on common trust fund advertising). As discussed in note 129 supra, the Comptroller of the Currency's Regulation 9 prohibits separate publicity respecting common trust funds other than with general promotion of the availability of fiduciary services of the bank, although the annual financial report containing investment performance data may be distributed and publicized in that general promotional effort. Investment performance may be compared with the Dow Jones and Standard and Poor's 500 indexes. CoMPTROLlER's HANDBOOK app., Precedents and Opinions, E-1, at $\uparrow 9.5110$, and there are no advertising restrictions on collective investment trusts for employee benefit plans, id. at E-4, at $₫ 9.6110$. On the other hand, for the past several years the trust departments of larger banks have voluntarily published annual reports providing a substantial amount of the information which would be included in annual and quarterly reports required to be filed by investment companies.

It should be noted, however, that Federal Reserve Board Regulation Y prohibits a bank from being involved in the distribution of prospectuses or sales literature respecting its serving as investment adviser to an investment company. 12 C.F.R. $\$ 225.125(\mathrm{~h})$ (1977).

133. 15 U.S.C. $\$ 80 \mathrm{a}-9$ (1970).

134. 15 U.S.C. $\S 80 \mathrm{~b}-3$ (e) (Supp. V 1975). This section was reworked substantially by the Securities Acts Amendments of 1975, Pub. L. No. 94-29, 89 Stat. 167. For a description of the changes made, see Lybecker, supra note 113.

135. 15 U.S.C. \& 78o(b)(4) (Supp. V 1975).

136. Securities Exchange Act $\$ 15(b)(7)$, 15 U.S.C. $\$ 78 o(b)(7)$ (Supp. V 1975); SEC Securities Exchange Act rules 15b8-1 to -2, 17 C.F.R. $\$ \$ 240.1568-1$ to -2 (1977). See 2 Loss 1288-1343; 
adopted rules addressed to broker-dealer financial responsibility, including acceptance and use of customers' securities, carrying and use of customers' securities, carrying and use of deposits or credit balances, and maintenance of reserves respecting customers' deposits or credit balances. ${ }^{138}$ Legislation was proposed during the 95 th Congress ${ }^{139}$ which would have provided parallel authority under the Investment Advisers Act to establish rules regarding professional and financial responsibility and to register selfregulatory organizations.

An investment company also must have a minimum net worth, ${ }^{140}$ and meet bonding requirements ${ }^{141}$ and rules governing custody of investment company portfolio securities. ${ }^{142}$ Finally, an investment company is prohibited from protecting by indemnification any officer or director of the investment company or its investment adviser or principal underwriter from liability for gross negligence. ${ }^{143}$ The Commission is authorized to adopt rules to prevent fraudulent or deceptive practices in connection with the purchase or sale of securities held or intended to be acquired by an investment company, and to require adoption of codes of ethics by investment companies and their investment advisers and principal underwriters. ${ }^{144}$

5 id. 3349-3406 (Supp. 1969). See generally E. Weiss, Registration and Regulation of Brokers and Dealers (1965); N. Wolfson, R. Phillips \& T. Russo, Regulation of BroKERS, DEALERS AND SeCURITIES MaRKETS (1977).

137. NASD MANUAL $\mathbb{1} 1102$ (CCH). See generally White, National Association of Securities Dealers, Inc., 28 Geo. WASH. L. REv. 250 (1959).

138. Securities Exchange Act § 15(c)(3), 15 U.S.C. § 78o(c)(3) (Supp. V 1975); SEC Securities Exchange Act rules 15c3-1 to -3, 17 C.F.R. § 240.15c3-1 to -3 (1977). See 2 Loss 1346-55; 5 id. 3406-08 (Supp. 1969).

139. See note 113 supra. See also SEC Investment Advisers Act rule 206(4)-2, 17 C.F.R. § 275.206(4)-2 (1977) (custody or possession of funds or securities of clients by investment advisers).

140. Investment Company Act $\S 14,15$ U.S.C. $\S 80 a-14$ (1970) (minimum net worth of $\$ 100,000)$.

141. Investment Company Act $\S 17(\mathrm{~g}), 15$ U.S.C. $\$ 80 \mathrm{a}-17(\mathrm{~g})$ (1970); SEC Investment Company Act rule 17g-1, 17 C.F.R. $\$ 270.17 \mathrm{~g}-1$ (1977).

142. Investment Company Act $\S 17(f), 15$ U.S.C. $\& 80 \mathrm{a}-17(f)$ (1970); SEC Investment Company Act rules 17f-1, 17f-2, 17 C.F.R. $\S \S 270$. 17f-1 to -2 (1977).

143. Investment Company Act $\$ 17(\mathrm{~h})$, (i), 15 U.S.C. $\$ 80 \mathrm{a}-17$ (h), (i) (1970) ("willful misfeasance, bad faith, or gross negligence, in the performance of his duties, or by reason of his reckless disregard of his obligations and duties").

144. Investment Company Act $\S 17(\mathrm{j}), 15$ U.S.C. $\S 80 \mathrm{a}-17(\mathrm{j})(1970)$. This section gocs beyond the usual antifraud provisions in that it authorizes the SEC by rule to declare unlawful "insider trading" by affiliated and access persons of an investment company in securities the company holds or intends to acquire. Id. (emphasis added). The Commission proposed rule 17j1 , but recently withdrew it for further consideration of the area. Compare SEC Investment Company Act Release No. 7581 (Dec. 26, 1972), [1972-1973 Transfer Binder] FED. SEC. L. REP. (CCH) If 79,157, with SEC Investment Company Act Release No. 9169 (Feb. 19, 1976), [19751976 Transfer Binder] FED. SEC. L. REP. (CCH) I 80,537. The proposed rule probably would have given the Commission and the investment company a cause of action against the "insider" whether or not the investment company also had been a purchaser or a seller of the security. But see Blue Chip Stamps v. Manor Drug Stores, 421 U.S. 723 (1975). 
Investment advisers are generally deemed to have a substantial fiduciary duty to their clients, ${ }^{145}$ as are broker-dealers under certain circumstances. ${ }^{146}$ The board of directors of an investment company must be composed of persons no less than forty percent of whom are not "interested persons" of the investment company, its investment adviser, or its principal underwriter. ${ }^{147}$ Paragraphs (a) and (b) of section 36 authorize the SEC to obtain injunctions against persons associated with an investment company for breach of fiduciary duty involving personal misconduct and, along with

The code of ethics requirement in proposed rule $17 \mathrm{j}-1$ was also important. For a discussion of the problems of disclosure of investment advice, see Fleischer, Mundheim \& Murphy, An Initial Inquiry Into the Responsibility to Disclose Market Information, 121 U. PA. L. REv. 798, 824-40 (1973).

145. SEC v. Capital Gains Res. Bureau, Inc., 375 U.S. 180 (1963) (investment adviser enjoined from purchasing stock shortly before publishing recommendation, then selling shortly afterwards; disclosure of practice necessary to preserve climate of fair dealing to maintain public confidence in the securities industry and to preserve the economic health of the country); accord, Kidder, Peabody \& Co., SEC Securities Exchange Act Release No. 8426 (Oct. 16, 1968), [1967-1969 Transfer Binder] FED. SEC. L. REP. (CCH) T 77,618. See also Securities \& Exchange Comm'N, Special Study of the Securities Markets, H.R. Doc. No. 95, supra note 52 , at $65-102$.

146. Chasins v. Smith, Barney \& Co., Inc., 438 F.2d 1167 (2d Cir. 1971) (duty when a fiduciary to act as an agent); Hecht v. Harris, Upham \& Co., 430 F.2d 1202 (9th Cir. 1970); Charles Hughes \& Co. v. SEC, 139 F.2d 434 (2d Cir. 1943), cert. denied, 321 U.S. 786 (1944) ("shingle theory" that broker-dealer going into business impliedly represents that he will deal fairly and honestly with his customers); SEC Securities Exchange rule 15c1-3, 17 C.F.R. \& 240.15c1-3 (1977); see SEC Securities Exchange Act rule 15c1-7, 17 C.F.R. \& 240.15c1-7 (1977); 3 Loss 1500-08; Art. III, § 2, NASD Rules of Fair Practice, NASD ManUaL (CCH) \2152, SEC Securities Exchange Act rule 15b10-3, 17 C.F.R. $\$ 240.15 b 10-3$ (1977) (suitability of investments). See also Note, Churning by Securities Dealers, 80 HARv. L. REv. 869 (1967) (excessive trading for a discretionary account). A very recent case, Rolf v. Blyth, Eastman Dillon \& Co., Inc., [Current] FED. SEC. L. REP. (CCH) I 96,275 (2d Cir. 1978), has caused considerable comment because it held a broker liable as an aider and abettor where he lent assistance to the alleged fraud by processing buy and sell orders and gave repeated assurances of confidence in an investment adviser without disclosing in reckless disregard of his fiduciary duties the fraudulent management of the account.

147. Investment Company Act $\$ 10(a), 15$ U.S.C. $\$ 80 \mathrm{a}-10(\mathrm{a})$ (1970). Certain no-load funds have less stringent requirements. Id. $\S 80 \mathrm{a}-10(\mathrm{~d})$. The term "interested person" is a very broad and intricate term of art defined in Investment Company Act $\S 2(a)(9), i d$. $\S 80 a-2(a)(9)$, a subset of which is an "affiliated person" of the company, defined in Investment Company Act $\S$ 2(a)(3), id. $\S 80 \mathrm{a}-2(\mathrm{a})(3)$. For the legislative history of "interested person," see North 718-20. For a discussion of suggested changes to be made in the two definitions in the ALI Federal Securities Code, see Rosenblat \& Lybecker 625-26.

There are further restrictions on the board of directors in section 10 of the Investment Company Act depending on employment relationships between an investment company and brokers, underwriters and investment bankers. Investment Company Act $\S 10(\mathrm{~b})(1)-(\mathrm{b})(3), 15$ U.S.C. $\$ \S 80 \mathrm{a}-10(\mathrm{~b})(1)-(b)(3)$ (1970). For the definitions of "broker," "principal underwriter" and "investment banker," see, respectively, Investment Company Act $\$ \S 2(a)(6), 2(a)(29)$ and 2(a)(21), id. $\S \S 80 \mathrm{a}-2(\mathrm{a})(6),-2(\mathrm{a})(29),-2(\mathrm{a})(21)$. Section $10(\mathrm{c})$ also prohibits persons who are officers, directors or employees of any one bank from constituting a majority of the board. Investment Company Act $\S 10(\mathrm{c})$, id. $\S 80 \mathrm{a}-10(\mathrm{c})$. 
shareholders, for breach of fiduciary duty involving the investment advisory fee, compensation for services or any payments of a material nature. ${ }^{148}$

To exercise fiduciary powers, banks must obtain permission from the appropriate federal or state regulatory agency. ${ }^{149} \mathrm{An}$ application addressed to the Comptroller of the Currency must discuss sufficiency of capital, needs of the community, general financial condition of the bank, general character and ability of the management of the bank, nature of supervision to be given to the fiduciary activities (including the qualifications, experience and character of the proposed officers of the trust department) and the availability of legal counsel. ${ }^{150}$ Any officer or director of a member bank of the Federal Reserve System may be removed for violations of law or any continuing unsafe or unsound banking practice, ${ }^{151}$ and no officer, director or employee of an investment banking firm may serve as an officer, director or employee of a member bank. ${ }^{152} \mathrm{~A}$ trust department's investments for its trust accounts must be kept separate in custody from the bank's assets, and the custodian employees must be bonded. ${ }^{153}$ Finally, mistakes made in good faith and in the exercise of due care in connection with the administration of a collective investment trust fund will not be deened a violation of Regulation 9 if, promptly after discovery of the error, the bank takes practicable corrective action. ${ }^{154}$ There are no provisions in the federal banking laws directed solely at the financial responsibility of a trust department as a unit of a bank, nor are there any professional qualification standards for trust department personnel. There exists no self-regulatory organization of banks (other than the Trust Division of the American Bankers Association) which would propose and monitor ethical standards for behavior by its members.

148. Investment Company Act $\S \S 36(\mathrm{a}),(\mathrm{b}), i d$. $\$ \S 80 \mathrm{a}-35(\mathrm{a})$, (b). For the legislative history of these sections, see North 726-28; for comments on section 36 as amended by the 1970 Act, including a discussion of the availability of private rights of actions, see Freedman \& Rosenblat, Duties to Mutual Funds, 4 Rev. SEc. Reg. 937 (1971) (then-Director and Chief Counsel, SEC Division of Corporate Regulation).

149. E.g., 12 U.S.C. $\& 92 \mathrm{a}(\mathrm{a})$ (1970) (Comptroller of the Currency respecting national banks).

150. 12 C.F.R. $\$ \S 9.2-.3$ (1977). The minimum capital for a national bank is $\$ 100,000$ if organized in a community with more than 6,000 inhabitants. 12 U.S.C. $\S 51$ (1970). Unlike an investment company examination, a trust department examiner would be expected to prepare, in addition to financial statements, an analysis of a bank trust department's organization and administration. COMPTROLLER's EXAMINATION MANUAL 39-40.

151. 12 U.S.C. \& 1818(e) (1970) (Comptroller of the Currency as to national banks; FDIC and Federal Reserve Board as to state-chartered insured banks). See id. \$ 1829 (prohibition against officers, directors or employees who have been convicted criminally of an offense involving dishonesty or breach of trust); id. $\$ 72$ (director must be citizen of United States, resident of the state and own $\$ 1,000$ of stock in the bank). See also 12 C.F.R. $\$ 7.4200-10$ (1977) (interpretive rulings of Comptroller regarding directors).

152. Glass-Steagall Act $\& 32,12$ U.S.C. $\$ 78$ (1970).

153. 12 C.F.R. $\$ 9.13$ (a) (1977).

154. Id. $\$ 9.18(\mathrm{~b})(14)$. 


\section{Compensation.}

An investment company needs an investment adviser, principal underwriter, broker-dealers to execute its transactions and someone to provide administrative services. Section 15 of the Investment Company Act ${ }^{155}$ requires that the contracts between an investment company and its investment adviser and principal underwriter be executed in writing and provide in substance for automatic termination upon assignment; ${ }^{156}$ it permits such contracts to continue beyond the original two-year term if the board of directors or a majority of both the investment company's outstanding voting securities and disinterested directors annually re-approves their continuance; and it requires a majority of the disinterested directors to approve the terms of the contracts. ${ }^{157}$ Moreover, section 205 of the Investment Advisers Act prohibits incentive performance fees except under certain conditions, ${ }^{158}$ and

155. 15 U.S.C. $\$ 80 \mathrm{a}-15$ (1970). The legislative history of section 15 and the controversy preceding its adoption in 1970 are discussed in Freedman \& Rosenblat, supra note 148, at 93839; Nutt, A Study of Mutual Fund Independent Directors, 120 U. PA. L. REv. 179, 186-202 (1971). For SEC Investment Company Act rules exempting certain investment advisory contracts from the strict provisions of section 15, see rule 15a-1 (small investment advisory contracts) and rule 15a-3 (certain registered insurance company separate accounts), 17 C.F.R. § 270.15a-1, .15a-3 (1977).

156. 15 U.S.C. $\$ \S 80 \mathrm{a}-15$ (a), (b) (1970). See also Investment Advisers Act $\S 205(2)$, id. $\S 80 \mathrm{~b}-$ 5(2). The term "assignment" is defined in Investment Company Act § 2(a)(4), id. \& 80a-2(a)(4). As to investment advisory contracts, sections $15(\mathrm{a})(1)$ and (a)(3) require that the contract precisely describe all compensation to be paid thereunder, and provide for termination upon sixty days' written notice. Id. $\$ \$ 80 \mathrm{a}-15$ (a)(1), (a)(3). See Rosenfeld v. Black, 445 F.2d 1337 (2d Cir. 1971), cert. dismissed, 409 U.S. 802 (1972) (sale of fiduciary office for profit prohibited); Ivy Fund, Inc., SEC Investment Company Act Release No. 8687 (Feb. 25, 1975), 6 SEC Docket 360 (1975) (exemptive order permitting appointment of interim investment adviser after the investment company's board of directors terminated its agreement with the prior investment adviser).

157. 15 U.S.C. $\$ 80 a-15$ (c) (1970 \& Supp. V 1975). Section 15(c) goes on to state with respect to the investment advisory contract that the disinterested directors have a duty to request and evaluate "such information as may reasonably be necessary to evaluate the terms" of the contract. Id. See also Moses v. Burgin, 445 F.2d 369 (1st Cir. 1971), cert. denied, 404 U.S. 994 (1971) (advisers must present to disinterested directors the possibility of establishing a brokerdealer affiliate for the purpose of recapturing brokerage commissions on behalf of the mutual funds). For both the advisory and principal underwriter contracts, the disinterested investors are required by section 15 (c) to cast their votes in person at a meeting called for the purpose of voting on the contracts. SEC Investment Company Act Release No. 6336 (Feb. 2, 1971), [19701971 Transfer Binder] FED. SEC. L. REP. (CCH) I 77,951.

158. 15 U.S.C. $\$ 80 \mathrm{~b}-5(1)$ (1970). The prohibition in section 205(1) was eased somewhat with expansion of the unnumbered paragraph following section 205(3) by the Investment Company Amendments Act of 1970. For a discussion of the legislative history of the incentive performance fee restrictions, see North 728-29. The Commission has adopted two rules under section 205 interpreting the unnumbered paragraph following section 205(3). SEC Investment Advisers Act rules 205-1 and 205-2, 17 C.F.R. \$§ 275.205-1, .205-2 (1977). For discussion of the rules see Fink, Performance Fees, 5 Rev. Sec. Reg. 829 (1972); Jansson, Whatever Happened to Performance Fees, INST. INV. 101 (June, 1974). 
section 36(b) of the Investment Company Act deems an investment adviser (and its affiliates) to have a fiduciary duty with regard to the advisory fee, compensation for services or any payments of a material nature. ${ }^{159}$ Section 17(e) of the Investment Company Act limits the amount of compensation that affiliated persons acting as brokers may receive from the investment company. ${ }^{160}$ At present, contracts with affiliated persons involving administrative services are not subject to the review procedures of section $15,,^{161}$ and may not be within the conflict of interest prohibitions of Investment

159. 15 U.S.C. $\$ 80 a-35$ (b) (1970). See note 164 infra. For cases discussing the reasonableness of investment company advisory fee arrangements, see Brown v. Bullock, 294 F.2d 415 (2d Cir. 1961); Boyko v. The Reserve Fund, [Current] FED. SEC. L. REP. (CCH) I 96,195 (S.D.N.Y. 1977) (settlement approved of revised schedule for determining annual compensation, and of internal safeguard against excessive compensation); Saxe v. Brady, 184 A.2d 602 (Del. Ch. 1962). See also Jennings \& Marsh 1533-39.

160. 15 U.S.C. $\$ 80 a-17$ (e) (1970). Section 17(e) prohibits any affiliated person (or person affiliated with such person) of a registered investment company when: (1) acting as agent, from accepting any compensation from any source for the purchase or sale of any property to or from the investment company except in the course of the person's business as an underwriter or broker; or (2) acting as broker, in connection with the sale of securities to or by the investment company, from receiving from any source a commission, fee, or other remuneration which exceeds (A) the usual and customary brokerage commission if the sale is executed on a securities exchange, (B) two percent of the sales price if executed in a secondary distribution, or (C) one percent of the sales price if otherwise effected. See In re Investors Research Corp., [1976-1977 Transfer Binder] FED. SEC. L. REP. (CCH) I 80,656 (use of investment company brokerage commissions to purchase computer services from affiliated persons held to violate $\S$ 17(e)); SEC Law Judge Finds Investors Research Violated Securities Laws, Wall St. J., July 27, 1976 , at 4, col. 3. Section $17(\mathrm{e})(2)(C)$ gives the Commission rulemaking power, as yet unexercised, to permit larger commissions if they are in the public interest and consistent with the protection of investors. See also Securities Exchange Act $\S \S 11(\mathrm{a})(1)-(2), 15$ U.S.C. $\S \S$ 78k(a)(1)-(2) (Supp. V 1975) (amending 15 U.S.C. $\$ \S 78 \mathrm{k}(\mathrm{a})(1)-(2)$ (1970)) (prohibitions on executing transactions for associated persons, effective May 1, 1978); SEC Securities Exchange Act rule 19b-3, 17 C.F.R. $\$ 240.19 b-3$ (1977) (requiring negotiated brokerage commission on national securities exchanges).

161. 15 U.S.C. \& 80a-15 (1970 \& Supp. V 1975). Operation of an investment company necessarily involves: preparation, printing and distribution of prospectuses, shareholder reports and proxy materials; issuance, transfer and cancellation of share certificates; payment of dividends and capital gains distributions; custody of portfolio securities and other assets; transfer, receipt and delivery of portfolio securities bought and sold; and computation, usually at least once daily, of offering and redemption prices of the investment company's shares. Securities \& Exchange Comm'n, Public Policy implications of Investment Company GROWTH, supra note 52, at 86-87. In terms of dollar impact, contracts for administrative services may be as material to investment company shareholders as investment advisory or principal underwriter contracts. Id. 92-93. Although these duties were traditionally undertaken either by the investment company itself or by unrelated third parties such as commercial banks otherwise in the business of providing such services, there has been a move in recent years to contract for such services with a person affiliated with the investment adviser or principal underwriter. Id. 90-94. For a recommendation that the investor protection provisions of sections 15,17 and 36 of the Investment Company Act should be amended explicitly to cover administrative services, see Rosenblat \& Lybecker 629-35. 


\section{Company Act sections $17(\mathrm{a})^{162}$ or $17(\mathrm{~d}),{ }^{163}$ or subject to the fiduciary duty provisions of sections $36(a)$ and $36(b) .164$}

162. 15 U.S.C. $\S 80 a-17$ (a) (1970). It might be argued that execution by an investment company of a contract providing for the rendition of administrative services by an affiliated person is a sale by the affiliated person of "other property" to the investment company within the imeaning of section 17(a)(1). Id. \& 80a-17(a)(1). Cf. Ivy Fund, Inc., SEC Investment Company Act Release No. 6509 (May 6, 1971), [1970-1971 Transfer Binder] Fed. SEc. L. REP. $(\mathrm{CCH})$ ๆ 78,069 (consideration to be paid by investment adviser for license to use investment company's name for itself found not to be fair and reasonable; section 17(b) application forexemption from section 17(a)(2) denied); Letter from SEC Division of Corporate Regulation to Union Data Service Center, Inc. (July 24, 1972), [1972-1973 Transfer Binder] FED. SEC. L. REP. (CCH) I 78,994 (no-action letter given where an affiliated broker-dealer wished to utilize the data processing services of an affiliate of the investment company on terms of cost of services plus $15 \%$ ).

It should be noted that section $17(\mathrm{c})$ provides an exception to the prohibitions of section 17(a) with respect to leasing services, although it has never been clear in whose ordinary course of business the leasing transaction must be. See Rosenblat \& Lybecker 634 n. 153.

163. 15 U.S.C. $\$ 80 \mathrm{a}-17$ (d) (1970); SEC Investment Company Act rule 17d-1, 17 C.F.R. $\S$ 270.17d-1 (1970). The Commission staff has for some time asserted the applicability of section 17(d) to the execution by an investment company of a contract for stock transfer agency services with an affiliated person. Address by SEC Commissioner Owens, Mutual Fund Seminar, Dallas, Texas (May 6, 1971), 101 SEC. REG. \& L. REP. (BNA) at E-1 (May 12, 1971). In February 1974 the Commission proposed that rule 17d-1(c) be amended to remove existing uncertainties and to clarify the circumstances under which affiliated persons could enter into service contracts with the investment company. SEC Investment Company Act Release No. 8245 (Feb. 25, 1974), [1973-1974 Transfer Binder] FED. SEC. L. REP. (CCH) I 79,667 (proposed rule $17 \mathrm{~d}-1(\mathrm{c})(\mathrm{ii}))$. The proposed amendments would add new clause (ii) to paragraph (c) to exclude service contracts from the definition of "joint enterprise" if they meet certain conditions: (1) the service contract is written, approved and renewed in the manner required for investment advisory contracts by sections 15 (a) and 15(c); and (2) a majority of the disinterested directors determine that (a) the contract is in the best interest of the company and its shareholders, (b) the services to be performed are required for the operation of the company, (c) the affiliated person can provide services at least equal in quality and nature to those provided by others offering the same or similar services, and (d) the fees are fair and reasonable in light of the usual and customary charges made by others for services of the same nature and quantity. Proposed SEC Investment Company Act rule 17d-1(c)(ii) is reproduced at 4 FED. SEC. L. REP. (CCH) ๆ 48,392.

164. 15 U.S.C. $\S \S 80 a-35$ (a), (b) (1970). Under section 36(b), an investment adviser to an investment company is deemed to have a fiduciary duty with respect to receipt of compensation for services or payments of a material nature to the investment adviser or to a person affiliated with the investment adviser. Thus, payments for administrative services performed by an investment adviser or its affiliate would be covered by section 36(b), except that section 36 (b)(4) excludes from the fiduciary duty provisions all compensation or payments made in connection with section 17 . Thus, if separate contracts for administrative services were subject to section 17 (d) and rule $17 \mathrm{~d}-1$, they could not be attacked directly under section $36(\mathrm{~b})$, although the legislative history of section 36 (b) suggests that such payments for administrative services could be taken into account in determining the reasonableness of overall management compensation. Hearings on H.R. 11995, S. 2224, H.R. 13754, and H.R. 14737 Before the Subcomm. on Commerce \& Finance of the House Comm. on Interstate \& Foreign Commerce, supra note 92, pt. 1, at 177-78 (testimony of SEC Chairman Budge). Since section 36(b) applies only to an investment company's investment adviser and the adviser's affiliates, it would not affect an investment company's principal underwriter and its affiliates, or any other persons affiliated with the investment company who otherwise would not have a fiduciary duty with respect to such compensation and payments. 
The Comptroller of the Currency's Regulation 9 limits the amount a bank may receive for acting in a fiduciary capacity, where not subject to restrictions under local law or approval by a court, to an amount which is "reasonable compensation for its services." 165 In the context of a collective investment trust fund, such amount cannot exceed the total amount which would have been charged had the trust account not participated in the collective investment trust fund. ${ }^{166}$ Since a bank trust department does not have a board of directors independent of that of the bank's, it acts in effect as its own principal underwriter, and typically provides all the administrative services. Because a bank cannot engage in the business of dealing in securities but is limited to purchasing and selling securities without recourse for its own customers, ${ }^{167}$ there are no provisions in the federal banking laws parallel to many of the provisions discussed above in the federal securities laws.

\section{Suitability of Investments. ${ }^{168}$}

Both the NASD ${ }^{169}$ and $S E C^{170}$ have rules which provide that a brokerdealer may recommend the purchase of a security only when there is a reasonable basis for believing that the security is "suitable" for the custom$\mathrm{er}$, and the SEC generally has found liability in circumstances where the investment portfolio was advised to assume risks out of proportion with the client's financial resources. ${ }^{171}$ There are no explicit parallel statutory provi-

165. 12 C.F.R. $\$ 9.15$ (a) (1977). Paragraph (b) thereof prohibits an officer or employee of a bank who is serving as co-fiduciary with the bank from receiving any compensation for so serving without specific approval of the bank's board of directors. Id. $\$ 9.15$ (b).

166. Id. $\$ 9.18(\mathrm{~b})(12)$. See Comptroller's Examination Manual 103.

167. Glass-Steagall Act $\S \S 21,24$ (seventh paragraph), 12 U.S.C. $\S 24$ (Supp. V 1975) (national banks); 12 U.S.C. $\$ 335$ (1970) (state-chartered member banks of the Federal Reserve System); id. § 378(a) (state-chartered banks and trust companies).

168. See Lipton, The Customer Suitability Doctrine, in FourTh ANNuAL INSTITUTE ON Securities Regulation 273 (R. Mundheim, A. Fleischer, Jr. \& J. Schupper eds. 1973); O'Boyle, Suitability, in Conference on SeCurities Regulation 94 (R. Mundheim ed. 1965); Cohen, The Suitability Rule and Economic Theory, 80 YALE L.J. 1604 (1971); Mundheim, Professional Responsibilities of Broker-Dealers: The Suitability Doctrine, 1965 DukE L.J. 445; Note, The Regulation of Risky Investments, 83 HARV. L. REv. 603 (1970). Professor Robert C. Clark has extensively analyzed the economic effect of portfolio registration restraints and concluded that they are of doubtful efficacy and are based on archaic concepts of risk, but that they are also the least harmful of regulatory techniques and are perhaps justifiable. Clark, supra note 117 , at $44-77$. His analysis would also appear to apply to restrictions on capital structure and investment decisionmaking, discussed in text accompanying notes 206-26 infra.

169. Art. III, $\S 2$ of NASD Rules of Fair Practice, NASD ManuAL (CCH) $₫ 2152$.

170. SEC Securities Exchange Act rule 15b10-3 (1976), 17 C.F.R. $\S 240.15$ b10-3 (1977).

171. See, e.g., Richard N. Cea, 44 S.E.C. 8 (1969); Gerald M. Greenberg, 40 S.E.C. 133 (1960); Thomas Arthur Stewart, 20 S.E.C. 196 (1945). The private civil liability damage cases are not as clearly articulated. See Hecht v. Harris, Upham \& Co., 430 F.2d 1202 (9th Cir. 1970); Buttrey v. Merrill Lynch, Pierce, Fenner \& Smith, Inc., 410 F.2d 135 (7th Cir.), cert. denied, 396 U.S. 838 (1969). An interesting recent suitability case was settled before adjudication, but 
sions regarding suitability respecting investment companies or investment advisers, although such a concept surely falls within the general fiduciary duties imposed by the Investment Company and Investment Advisers Acts. On one hand, there are a number of provisions in the Investment Company Act which do restrict, directly or indirectly, the types of securities an investment company may sell. The purpose of those restrictions appears to be to limit possible risk-taking, rather than to create positive duties aimed at investment performance or suitability. ${ }^{172}$ On the other hand, the Comptroller of the Currency clearly alludes to the suitability concept in Regulation $9^{173}$ and the Comptroller's Examination Manual gives extensive instructions regarding testing for suitability. ${ }^{174}$

\section{Conflicts of Interest.}

Because of the absence of a true arm's-length bargaining relationship between an investment company's investment adviser and the investment company itself, section 10 of the Investment Company $\mathrm{Act}^{175}$ requires that no less than forty percent of an investment company's board of directors be persons who are not affiliated with or interested parties of the investment company, its investment adviser or its principal underwriter. The Investment Company Act goes on to address certain specific conflict of interest situations by requiring, for example, that certain procedures (involving imposition of heavy responsibility on the disinterested directors) be followed in execution of the investment advisory and principal underwriting

the complaint alleged unsuitability of investments totalling $\$ 4$ million on sixteen speculative securities, even though the portfolio as a whole had performed favorably by over six percent cumulative per year. Trustees of Hanover College v. Donaldson, Lufkin \& Jenrette, Inc., Civil No. 71-C686 (S.D. Ind. 1971); Wall St. J., Jan. 26, 1973, at 6, col. 3; Wall St. J., Dec. 13, 1971, at 9, col. 3. See Belliveau, Discretion or Indiscretion, INST. INV. 65 (Aug. 1972).

172. See text accompanying notes 202-26 infra.

173. 12 C.F.R. $\$ 9.11(\mathrm{~d})$ (1977).

174. Comptroller's Examination Manual 60, 73-80. A bank is expected to review all assets held for trust accounts where the bank has investment discretion at least once every calendar year and within fifteen months of the previous review. Id.73-74. The trust examiner is required to consider "not only the basic merits of the various securities comprising the account portfolio, but also the legal propriety and the appropriateness of holding them in the particular account." Id. 74. Then, the trust examiner also should review all investments by the bank. Id. 75-76. See also COMPTROLLER's HANDBOOK app. III, at 37-41 (Examination Procedures Checklist).

175. 15 U.S.C. \& 80a-10 (1970). See note 147 supra.

Professor Robert C. Clark has extensively analyzed the economic effect of regulations addressed to insider misconduct, and concluded that, because of relatively low economic costs and lack of offensive side effects, insider misconduct regulation is a strategy which should be implemented. Clark, supra note 117, at 77-86. 
contracts. ${ }^{176}$ Section 17 of the Act ${ }^{177}$ prohibits other potentially severe conflict of interest transactions between an investment company and its investment adviser, its principal underwriter or other "affiliated" persons "78 unless advance SEC approval has been obtained through formal application procedures. ${ }^{179}$ Thus, section 17 (a) generally prohibits any affiliated person (or any persons affiliated with such affiliated person) of a registered investment company from selling, purchasing or borrowing securities or other property from the investment company. ${ }^{180}$ Section 17 (d) generally empowers the Commission to establish rules and procedures restricting any affiliated person (or any persons affiliated with such affiliated person) of a registered investment company, acting as principal, from effecting any transaction in which the investment company (or a company controlled by the registered investment company) ${ }^{181}$ is a joint or joint and several participant with the affiliated person. ${ }^{182}$ Similarly, to prevent abuses related to

176. 15 U.S.C. $\$ 80 \mathrm{a}-15$ (1970). See notes 155-157 supra.

177. 15 U.S.C. $\$ 80 \mathrm{a}-17$ (1970). The Commission has adopted a series of rules under section 17(a) and section 17(d), 15 U.S.C. $\$ \S 80 \mathrm{a}-17(\mathrm{a})$, (d) (1970), which exempt certain specified transactions from the prohibitions of those sections in circumstances where the need for Commission review is remote, and which thereby obviate the need for filing applications requesting an exemptive order provided for in section 17(b), 15 U.S.C. $\$ 80 \mathrm{a}-17$ (b) (1970), and rule 17d-1(d). See SEC Investment Company Act rules 17a-1 to 17a-7, 17d-1(d), 17 C.F.R. \$ $270.17 \mathrm{a}-1$ to $17 \mathrm{a}-7,17 \mathrm{~d}-1$ (d) (1977).

178. The term "affiliated person" is defined in Investment Company Act $\S 2(\mathrm{a})(3), 15$ U.S.C. $\S 80 \mathrm{a}-2(\mathrm{a})(3)$ (1970). Among others, any officer, director or employee of an investment company is an affiliated person of the investment company under section 2(a)(3)(D). Id. \& 80$2(a)(3)(D)$. For a suggested change to section 2(a)(3), see Rosenblat \& Lybecker 625-26. See also note 181 infra.

179. For the procedure for submitting a formal application seeking a Commission order, see SEC Investment Company Act rules 0-2, 0-5, 17 C.F.R. \& 270.0-2, .0-5 (1977). The standard for granting an order is found in various provisions, such as section 2(a)(9) ("control"), section 2(a)(19) ("interested person"), and section 6(c) (general exemptive orders). 15 U.S.C. \$\$ 80a2(a)(9), -2(a)(19), -6(c) (1970). Sections 17(b) and 17(d) also have their own standards for Commission review in granting exemptions, 15 U.S.C. $\$ \$ 80 \mathrm{a}-17$ (b), (d) (1970), although the scope of Commission inquiry regarding a section 17 (b) application is somewhat wider than that required for granting a section 17(d) application. See Rosenblat \& Lybecker 598 n.42, 642 n.175, 650-51.

180. 15 U.S.C. $\$ 80 \mathrm{a}-17(\mathrm{a})(1)$ to (a)(3) (1970).

181. The definition of "affiliated person" in Investment Company Act $\S 2(a)(3)(B)$ includes any company five percent of whose outstanding voting securities are owned by an investmcnt company, or so-called portfolio affiliates; section 17 (d) itself sweeps within its restrictions against joint transactions affiliates of affiliated persons, or so-called second level portfolio affiliates. 15 U.S.C. $\$ \S 80 \mathrm{a}-2(\mathrm{a})(3)(\mathrm{B}),-17$ (d) (1970). The best discussions of the application of section 17 to portfolio affiliates are Kroll, The "Portfolio Affiliate" Problem, in THIRD ANNUAL INSTITUTE on SECURITIES REgULATION 261 (R. Mundheim \& A. Fleischer, Jr. eds. 1972); Comment, The Application of Section 17 of the Investment Company Act of 1940 to Portfolio Affiliates, 120 U. PA. L. REv. 983 (1972). For suggested change to sections 17(a) and 17(d) to exclude persons who are affiliated with an investment company solely because of section 2(a)(3)(B), see Rosenblat \& Lybecker 651-54.

182. 15 U.S.C. $\$ 80 a-17$ (d) (1970); SEC Investment Company Act rule 17d-1, 17 C.F.R. $\S$ $270.17 \mathrm{~d}-1$ (1977). For the legislative and administrative history of section 17 (d) and rule 17d-1, and suggested changes to section 17(d), see Rosenblat \& Lybecker 643-51. 
distribution of an investment company's securities, Investment Company Act section $22(d)^{183}$ prohibits sales to the public of the investment company's securities except to or through its primcipal underwriter at the current public offering price described in the prospectus. ${ }^{184}$

There are also a number of possible conflict of interest problems which shade into ethical questions of fairness as between multiple clients where an investment adviser has more than one client ${ }^{185}$ and particular resources must be shared, including: bunching of orders to execute transactions to achieve net lower brokerage commission rates; allocation or disposition of securities where the available trading mechanisms permit less than the total desired participation by all advisory clients; allocation of research and market information in terms of the sequence and selectivity of the information disseminated; and use of brokerage commissions to purchase so-called Wall

183. 15 U.S.C. § 80a-22(d) (1970); SEC Investment Company Act rules 22d-1, 22d-2, 17 C.F.R. $\$ \$ 270.22 \mathrm{~d}-1, .22 \mathrm{~d}-2$ (1976). The Supreme Court recently discussed the legislative history and goals of regulation of mutual fund distribution in United States v. National Ass'n of Sec. Dealers, Inc., 422 U.S. 694 (1975). Investment Company Act section 22(a) authorizes the NASD to set minimum and maximum sales loads, 22(e) prohibits suspension of the right of redemption and $22(\mathrm{~g})$ prohibits the sale of shares for services or property other than cash. 15 U.S.C. $\$ \$ 80 a-22(a),(e),(g)(1970)$.

For descriptions of mutual fund sales distribution systems, see Division of INVESTMENT Management Regulation, Securities and Exchange Comm'n, Mutual Fund Distribution AND SECTION 22(D) OF THE INVESTMENT COMPANY ACT OF 1940, in CCH MUTUAL FUNDS Guide No. 155, pt. II (Nov. 8, 1974); Heffernan \& Jorden, Section 22(d) of the Investment Company Act of 1940-Its Original Purpose and Present Function, 1973 DukE L.J. 975; Conference on Mutual Funds: The Financing of Sales of Mutual Fund Shares, 115 U. PA. L. REv. 769 (1967). Collateral statutory protection of the integrity of investment company share distribution systems are found in Investment Company Act $\$ \$ 11$ (exchange offers), 23 (closed-end fund share distributions), 25 (reorganization plans), 26 (unit investment trust share distributions) and 27 (periodic payment plan share distributions). 15 U.S.C. \$§ 80a-11, 23, 25, 26, 27 (1970).

184. Rounding out the regulatory pattern for conflicts of interest between the investment company, its investment adviser and its affiliated persons are the Investment Company Act $\$ 21$ (loans by investment companies), 15 U.S.C. § 80a-21 (1970), and Investment Advisers Act $\S$ 206(3) (acting as principal in executing brokerage transactions for advisory clients without prior consent), id. § 80b-6(3); SEC Investment Advisers Act rule 206(3)-1, 17 C.F.R. § 275.206(3)-1 (1977). Rule 206(3)-1 exempts from section 206(3) certain "impersonal advisory services" provided by broker-dealers also registered under the Investment Advisers Act to the extent such services are available for public distribution, provide generalized advice not geared to the investment needs of any particular individual, and respond to requests for specific statistical information not involving an expression of opinion. See SEC Investment Advisers Act Release No. 557 (Dec. 2, 1976), [Current] FED. SEC. L. ReP. (CCH) \ 80,826 (proposed rule 206(3)-2 permitting agency cross-transactions by broker-dealers for advisory clients); SEC Investment Advisers Act Release No. 40 (Feb. 5, 1945) (consent and disclosure arrangement of section 206(3) could not be satisfied by a general agreement, but must be satisfied before completion of each separate transaction).

185. There is no question that a fiduciary may lawfully act in that capacity for several clients if all parties fully understand the situation. RESTATEMENT (SECOND) OF AGENCY \$§ 390-394 (1958); W. SEAVEY, LAW OF AGENCY 248 (1964). See Henderson, Conflicts of Interest for the Money Manager, in ThiRd ANNUAL INSTITUTE on SeCURITIES REgulation 293 (R. Mundheim \& A. Fleischer, Jr. eds. 1972). 
Street research. Unfortunately, it is easier to identify possible conflicts of interest than to formulate guidelines from present law for handling them. As to bunching, the SEC proposed, ${ }^{186}$ then recently withdrew, ${ }^{187}$ an amendment to Investment Company Act rule $17 \mathrm{~d}-1(\mathrm{~d})(4)$ which would have permitted a complex of investment companies under common control to accumulate, buy or sell orders across the complex for joint execution. Trading allocation formulas also have been adopted by many mutual fund complexes. ${ }^{188}$ Allocation formulas for dissemination of research or market information do not appear to have been widely adopted, ${ }^{189}$ but preferential disclosure by a broker-dealer to a few clients prior to publishing a market letter is clearly illegal, ${ }^{190}$ and the SEC apparently believes a broker-dealer has a duty to communicate to his clients any material changes from prior recommendations. ${ }^{191}$ In other respects, it seems clear that an investment adviser must at least treat equally all advisory clients of the same type. ${ }^{192}$ The controversy ${ }^{193}$

186. SEC Investment Company Act Release No. 7035 (Mar. 9, 1972), [1971-1972 Transfer Binder] FED. SEC. L. REP. (CCH) I 78,608.

187. SEC Investment Company Act Release No. 9170 (Feb. 19, 1976), [1975-1976 Transfer Binder] FED. SEC. L. REP. (CCH) ๆ 80,538.

188. Glazer, A Study of Mutual Fund Complexes, 119 U. PA. L. Rev. 205, 237-41 (1971). Item 1.33, Investment Company Act Form $\mathrm{N}-1 \mathrm{R}$, asks an investment company to state its trading allocation policy. 4 FED. SEC. L. REP. (CCH) If 51,963 , at 39,852.

189. Herman \& Safanda, Allocating Investment Information, FiN. ANAL. J. 23 (Jan.-Feb. 1973); Herman \& Safanda, Bank Trust Department Investment Services for Correspondent Banks, 48 IND. L.J. 427 (1973). For an information allocation formula of a well-known Wall Street research firm, see Henderson, supra note 185, at 301 (remarks of Gordon Henderson describing Sanford G. Bernstein \& Co., Inc.).

190. SEC v. Capital Gains Res. Bureau, Inc., 375 U.S. 180 (1963); accord, SEC v. Campbell, [1972-1973 Transfer Binder] FED. SEC. L. REP. (CCH) ๆ 93,580 (C.D. Cal. 1972) (summary of complaint), SEC Litigation Release No. 5645 (Nov. 22, 1972) (order of preliminary injunction), Wall St. J., Oct. 24, 1974, at 10, col. 2 (permanent injunction); Kidder, Peabody \& Co., Inc., SEC Securities Exchange Act Release No. 8426 (Oct. 16, 1968), [1967-1969 Transfer Binder] FED. SEC. L. REP. (CCH) ๆ 77,618; see NYSE, Guidelines for Member Firm Communications with the Public 5 (1970); NYSE, M.F. Circular No. 170 (Nov. 16, 1962); AMEX, Info. Circular No. $51-71$ (Apr. 30, 1971). See also FinanCial Analysis Federation, Corporate DisClOSURE AND INSIDE INFORMATION 15 (1968) (remarks of SEC Commissioner Loomis, Jr.).

191. Butcher \& Sherrerd, SEC Securities Exchange Act Release No. 9894 (Dec. 11, 1972), [1972-1973 Transfer Binder] FED. SEC. L. REP. (CCH) I 79,135 (findings and order imposing remedial sanction); Securities \& ExChange COMm'N, STATEMENT ON Future StruCture OF the Securities Markets, 137 Sec. Reg. \& L. Rep. (BNA) pt. 2, at 6 (Feb. 2, 1972). But see Henderson, supra note 185 , at 308 n. 25.

192. This would appear to conform to present expectations of advisory clients. Henderson, supra note 185, at 305 (remarks of SEC Commissioner Loomis, Jr.), 310 (remarks of Meyer Eisenberg); Loomis, The Merrill Lynch Bull is Loose on Wall Street, Fortune 174 (May 1972); Robards, Do Brokers Give Better Advice to Institutions?, N.Y. Times, Dec. 5, 1971, § F, at 2. But see Henderson, supra note 185, at 306-07 (remarks of Gordon Henderson); Leiman, Conflict of Interest and Related Problems of Broker-Dealers and Investment Advisers, in FIRST ANNUAL InSTITUTE ON SeCuRITIES Regulation 323, 333 (R. Mundheim, A. Fleischer, Jr., \& D. Glazer eds. 1970) (remarks of Arthur Fleischer, Jr. and Leonard Leiman).

193. See generally Jorden, "Paying Up" for Research: A Regulatory and Legislative Analysis, 1975 DUKE L.J. 1103, 1109-16; Lybecker, Regulation of Bank Trust Department Investment 
over the legality of use of brokerage commissions to purchase research was largely resolved by adoption in 1975 of new section 28(e) of the Securities Exchange Act, ${ }^{194}$ which permits the practice where it is determined in good faith that the amount of commission was reasonable in relation to the value of the brokerage and research services provided, in terms of that particular transaction or overall investment responsibility. ${ }^{195}$

Under the federal banking laws, there are few regulatory parallels to Investment Company Act sections 10, 17 and 22 because a trust department does not have a board of directors separate from those serving the bank as an entity, and because officers, directors and employees of a bank are not permitted to engage in the distribution of securities. ${ }^{196}$ On the other hand, banks can have possible conflicts of interest not generally found in the investment company industry regarding the use of uninvested cash and the making of loans. ${ }^{197}$ Bank trust departments are prohibited by the Comptrol-

Activities: Seven Gaps, Eight Remedies, 91 Banking L.J. 6, 18-23 (1974) (pt. 2); Pozen, Money Managers and Securities Research, 51 N.Y.U.L. REv. 923 (1976).

194. Securities Acts Amendments of 1975, Pub. L. No. 94-29, § 21(e), 89 Stat. 161-62 (codified at 15 U.S.C. \& 78bb(e) (Supp. V 1975)). See Herzel, "Paying Up" on Stock Brokerage Commissions Under Section 28(e) of the Securities Exchange Act, 31 Bus. Law. 1479 (1976); Jorden, supra note 193, at 1116-29; Pozen, supra note 193.

195. 15 U.S.C. $\$ 78 \mathrm{bb}(\mathrm{e})$ (Supp. V 1975). For recent interpretations of section 28(e), see SEC Securities Exchange Act Release No. 12251 (Mar. 24, 1976), [1975-1976 Transfer Binder] Fed. SEC. L. REP. (CCH) I 80,407; Letter from SEC Division of Market Regulation to Clinton T. Crolius, Esq. (June 26, 1977), [Current] Fed. Sec. L. REP. (CCH) I 81,428; Letter from SEC Division of Market Regulation to the Bank of New Jersey (June 15, 1976), [Current] FED. SEC. L. REP. (CCH) I 80,662; Letter from SEC Division of Market Regulation to Becker Securities Corporation (May 28, 1976), [Current] Fed. SEC. L. REP. (CCH) I 80,641; Letter from SEC Division of Market Regulation to American Bankers Ass'n (Apr. 23, 1976), [Current] Fed. SEC. L. REP. (CCH) I 80,607. The SEC has also issued proposed rule $28 \mathrm{e} 2-1$ which would require disclosure of brokerage practices by broker-dealers, investment companies and investment advisers. SEC Securities Exchange Act Release No. 13024 (Nov. 30, 1976), [Current] FED. SEC. L. REP. (CCH) I 80,873 (proposed rule 28e 2-1).

196. Glass-Steagall Act $\S \S 21,24$ para. seventh, 12 U.S.C. $\S 24$ (1970) (national banks); id. $\S$ 335 (state-chartered member banks of the Federal Reserve System); id. § 378(a) (state-chartered banks and trust companies).

197. 12 C.F.R. \$ 9.12 (1977). See 12 U.S.C. § 92a(h) (1970); 12 C.F.R. \$ 225.125(g) (1977). Sections 12(a) and (b) of Regulation 9 prohibit-unless authorized by the trust instrument, local law or a court order-investment or disposition of funds held in a fiduciary account in stock, obligations of, or property acquired from the bank or any of its affiliates. Id. §9.12(a), (b). See also id. $\S 9.18(b)(8)(i)$. Exceptions to the prohibitions exist to permit a bank to purchase defaulted bonds with respect to collective investment trust funds, id. $\$ 9.18(\mathrm{~b})(8)$ (ii), to resolve potential surcharge liability, id. $\S 9.12(b)(2)$, and where required by the Comptroller of the Currency, id. $\$ 9.12(\mathrm{~b})(4)$, presumably also in circumstances involving allegations of breach of fiduciary duty. Sections 12(e) and (f) of Regulation 9 go on, however, to authorize "in-house" loans between trust accounts where authorized by the trust instruments and bank loans to a trust account where the transaction is "fair" and not prohibited by local law. Id. \$§ 9.12(e), (f).

The Comptroller's Examination Manual focuses closely on the misuse of assets in conflict situations, COMPTROLLER'S EXAMINATION MANUAL 87-91, 102, and notes additionally that since banks are permitted to engage as principals in the distribution of certain U.S. and municipal 
ler of the Currency's Regulation 9 from investing in the stock or obligations of the bank or its affiliates, 198 but may execute "in-house" transactions between trust accounts if the transaction is "fair" to both accounts and not prohibited by the trust instrument or local law. ${ }^{199}$ Finally, the FDIC, based on its experience that abusive self-dealing had been a significant contributing factor in more than half of all bank failures since 1960 (with losses to the FDIC likely to exceed $\$ 175$ million) recently adopted strict conflict of interest prohibitions. These prohibitions cover all bank affiliates and ten percent shareholders with respect to all business transactions with a bank unless specifically approved by the bank's board of directors. ${ }^{200}$ As to the possible conflicts of interests among multiple clients, there are no provisions in either Regulation 9 or the Comptroller's Examination Manual addressed to best execution of securities transactions, and trading or information allocation formulas. Banks were, of course, the principal intended beneficiaries of new section 28(e) of the Securities Exchange Act. ${ }^{201}$

\section{Restrictions on Capital Structure and Investment Decisionmaking.}

With registration under the Investment Company Act, an investment company must disclose certain fundamental aspects of its intended investment policies and operations, including: diversification, borrowing, lending, issuance of senior securities, underwriting the securities of others, concentration of investments, purchase of assets other than securities, and portfolio turnover. ${ }^{202}$ Section 13 of the Investment Company $\mathrm{Act}^{203}$ prohibits changes or deviations from these fundamental policies without seeking and obtaining approval of a majority of its outstanding voting securities. ${ }^{204}$ Section 5(b)(1) of the Investment Company Act $^{205}$ and Subchapter M of the Internal Revenue Code also impose diversification requirements including: seventy-five percent of an investment company's total assets

obligations, 12 C.F.R. $\$ 1$ (1976), trust accounts should not buy such syndicated obligations until after the syndicate has closed. CoMpTROLLER's ExAMINATION MANUAL 91. See also COMPTROLLER's HANDBOOK app. III, at 52-55 (Examination Procedures Checklist).

198. 12 C.F.R. $\$ 9.12$ (c) (1977). However, if the governing trust instrument permits a bank to retain such stock or obligations, the bank is under no duty to sell the securities. Id.; see COMPTROLLER'S EXAMINATION MANUAL E-1.

199. 12 C.F.R. $\$ 9.12$ (d) (1977).

200. Id. $\S 337.3$; see id. $\S \S 7.7355-.7370,23.1-.5$ (transactions with affiliates, statements of business interest of directors of national banks).

201. See notes 194-95 supra.

202. 15 U.S.C. $\$ 80 \mathrm{a}-8(\mathrm{~b})(1970) ; c f . i d . \$ 80 \mathrm{~b}-3$ (c) (registration of investment advisers).

203. Id. \$ 80a-13(a). SEC Investment Company Act rule 13a-1 exempts from the prohibition any change in status from diversified to nondiversified in certain circumstances. 17 C.F.R. $\S$ 270.13a-1 (1977).

204. For a recommendation that the classifications in sections $8(\mathrm{~b})$ and $13(\mathrm{a})$ be amended to narrow their scope, see Rosenblat \& Lybecker 682-29.

205. 15 U.S.C. $\$ 80 a-5(b)(1)$ (1970). 
must be invested in cash, cash items or securities; of these assets, holdings in any one portfolio company cannot exceed five percent of the investment company's total assets or ten percent of the portfolio company's outstanding voting securities. ${ }^{206}$ Section 18 of the Investment Company Act contains important restrictions on investment company capital structure. Every share of stock issued by a registered management-type ${ }^{207}$ investment company must have voting rights equal to those of every other outstanding share of stock. ${ }^{208}$ Registered open-end investment companies cannot issue any senior securities, ${ }^{209}$ while closed-end funds can issue senior securities only where asset coverage is $300 \%$ for debt securities or $200 \%$ for preferred stock. ${ }^{210}$ Finally, the provisions in section 12 regarding portfolio investments complement section 18's capital structure restrictions by giving the Commission rulemaking authority over margin buying ${ }^{211}$ and short sales of securities, ${ }^{212}$ and by imposing severe limitations on the proportion of an investment company's portfolio which may be invested in the securities of

206. Most investment companies meet these diversification requirements, due in part to their desire to increase their appeal to the average potential investment company shareholder, and also due in part to the advantages stemming from qualification as a "regulated investment company" - a registered investment company meeting the Internal Revenue Code's somewhat different diversification requirements. I.R.C. $\$ 851$ (b) requires, in addition to the standards of Investment Company Act $\$ 5(\mathrm{~b})(1)$, that: (1) no more than twenty-five percent of an investment company's assets be invested in the securities of any one issuer, or of two or more issuers in the same or related business, which the investment company controls; and (2) less than thirty percent of an investment company's gross income must be derived from the disposition of securities held for less than three months. Failure to satisfy the additional requirements of Subchapter $M$ could result in loss of the favorable "pass through" tax treatment afforded investment companies.

207. Section 4 of the Investment Company Act, 15 U.S.C. $\$ 80 a-4$ (1970), provides for three different types of investment companies: (1) face-amount certificate companies, governed generally by sections 27 or 28 of the Act, id. $\$ \S 80 \mathrm{a}-27,-28 ;(2)$ unit investment trusts, which are governed generally by section 26 of the Act, id. $\S 80 \mathrm{a}-26$; and (3) all others, which are termed management companies.

208. 15 U.S.C. $\$ 80 a-18(i)$ (Supp. V 1975). This requirement of "shareholder democracy" may produce irreconcilable problems where the issuer falling within the definition of investment company is not a corporation or business trust. See, e.g., SEC Investment Company Act Release No. 8456 (Aug. 9, 1974), 39 Fed. Reg. 32, 129 (two-tier real estate limited partnerships).

209. IS U.S.C. \$ 80a-18(f)(1) (1970). Registered open-end companies may, however, borrow from banks if asset coverage is a minimum of $300 \%$ or in other limited circumstances. Id.; SEC Investment Company Act rule 18f-1, 17 C.F.R. $\$ 270.18 f-1$ (1977). The scope of the general definition of "senior security" in section $18(\mathrm{~g})$ is limited as to registered open-end investment companies by section 18(f)(2). 15 U.S.C. $\$ 80 \mathrm{a}-18(\mathrm{f})(2)$, $(\mathrm{g})(1970)$. When a company issues securities which would be senior but for section $18(f)(2)$ the SEC is authorized to prescribe special voting rights for the security holders. See SEC Investment Company Act rule 18f-2, 17 C.F.R. $\$ 270.18 f-2(1977)$.

210. 15 U.S.C. $\$ \S 80 \mathrm{a}-18(\mathrm{a})(1)(\mathrm{A}),(\mathrm{a})(1)(\mathrm{B})(1970)$. The terms "senior security" and "asset coverage" are defined in Investment Company Act $\$ \S 18(\mathrm{~g})$ and $18(\mathrm{~h})$, respectively. Id. $\$ \S 80 \mathrm{a}-$ $18(\mathrm{~g})$, (h).

211. Id. $\S 80 \mathrm{a}-12(\mathrm{a})(1)$.

212. Id. $\$ 80 \mathrm{a}-12(\mathrm{a})(3)$. 
other issuers in the investment company, ${ }^{213}$ insurance ${ }^{214}$ or securities industries. 215

An informal constraint on portfolio investment is provided by section 19 , which requires that dividends be paid only from accumulated net income not including capital gains or losses, and that capital gains be distributed not more frequently than every twelve months. ${ }^{216}$ Section 19 is backstopped by Subchapter $M$ of the Internal Revenue Code of 1954 which gives special income tax treatment to investment companies which distribute at least ninety percent of their ordinary income in the form of dividends. ${ }^{217}$ Finally, an investment company issuing redeemable securities must keep very liquid some amount of its investment portfolio so that it can meet the statutory commitment to prompt redemption of shares. ${ }^{218}$

The Comptroller of the Currency's Regulation 9 does not contain any restrictions on the changing of investment policy once a collective investment trust fund has been established, but does establish elaborate portfolio investment restrictions for common trust funds. ${ }^{219}$ First, no participant in a

213. Id. $\$ 80 \mathrm{a}-12(\mathrm{~d})(1)$. This section was extensively amended in 1970 to deal with problems of mutual fund holding companies. North 720-21 \& n.38. The Commission had proposed abolition of so-called funds-of-funds. SEcurities \& EXCHANGE COMM'N Public Policy IMPLICATIONS OF INVESTMENT COMPANY GROWTH, supra note 52, at 323.

214. 15 U.S.C. $\$ 80 \mathrm{a}-12(\mathrm{~d})(2)$ (1970); see id. $\$ 80 \mathrm{a}-12(\mathrm{~g})$ (limited exceptions for failing insurance companies where permitted by Commission order).

215. Id. $\$ 80 \mathrm{a}-12$ (d)(3); Investment Company Act rule 12d-1, 17 C.F.R. $\$ 270.12 \mathrm{~d}-1$ (1977) (conditional exemption for limited purchases or sales of securities from the prohibitions of section 12(d)(3)).

216. 15 U.S.C. $\$ \S 80 \mathrm{a}-19$ (a), (b) (1970); SEC Investment Company Act rules 19a-1, 19b-1, 17 C.F.R. \& 270.19a-1, 19b-1 (1976).

217. I.R.C. $\$ \S 851-855$. Subchapter $M$ actually makes the special income tax treatment of avoiding double taxation turn on diversification of investment, a concept identical to although tested somewhat differently from section $5(\mathrm{~b})(1)$ of the Investment Company Act. 15 U.S.C. § $80 \mathrm{a}-5(\mathrm{~b})(1)$ (1970). See notes 205-06 supra. For a thorough explanation of the special tax treatment afforded diversified investment companies, see SECURITIES \& EXCHANGE COMM'N, PuBliC POLICY IMPLICATIONS OF INVESTMENT COMPANY GROWTH, supra note 52, at 79-82.

218. 15 U.S.C. $\$ \S 80 \mathrm{a}-22(\mathrm{e})$, (f) (1970); SEC Investment Company Act rule 22e-1, 17 C.F.R. $\S 270.22 \mathrm{e}-1$ (1970).

219. The opening clause of 12 C.F.R. $\$ 9.18(b)(9)$ (1977) specifically excludes collective investment trust funds for employee benefit plans from the restrictions which follow in that section; presumably the exclusion is bottomed on the fact that some employee benefit plans intend to and do concentrate their investment portfolios in securities issued by the employer corporation.

In 1972 the Deputy Comptroller of the Currency for Trust announced that the Comptroller had under advisement some modifications of the restrictions in Regulation 9 discussed in notes 220-21 infra. Miller, Current Developments in Trust Supervision, 111 TR. \& EsT. 268 (1972). The proposed modifications would provide operating flexibility where excessive investments were caused by market fluctuations; a bank would be allowed twelve months in which to reduce the value of the holdings. Id. 343. To date, these proposed modificiations have not been proposed formally or adopted.

Finally, the Comptroller's Examination Manual suggests that no more than twenty percent of the principal of any trust account should be invested in the securities of any one issuer, 
common trust fund may have more than a ten percent interest in the fund; 220 moreover, no individual holding in any of the securities issued by any one company (not including the United States), can exceed ten percent of the market value of the common trust fund. ${ }^{221}$ Second, to have cash to deal promptly with requests for withdrawal, a bank is required to keep a sufficient amount of the fund in cash and readily marketable securities. ${ }^{222}$ There are special rules for servicing mortgages held by any collective investment fund, ${ }^{223}$ and for the purchase of shares issued by bank fiduciary funds ${ }^{224}$ and certain other issuers. ${ }^{225}$ Finally, collective investment funds can be invested in any other manner that is approved in writing by the Comptroller of the Currency. ${ }^{226}$

\section{Private Rights of Action.}

An essential feature of investor protection other than direct enforcement against violations by the appropriate federal regulatory agency is the private right of action permitting an aggrieved investor to pursue his remedies individually. Thus, sections $11,22712(1)^{228}$ and $12(2)^{229}$ of the Securities Act of 1933 provide for civil liability against various persons in the underwriting distribution chain (from the issuer to the broker-dealer) where

except where such securities are received in kind from the grantor. COMPTROLLER'S EXAMINATION MANUAL 78-79.

220. 12 C.F.R. $\S 9.18($ b)(9)(i) (1977). Investment Company Act $\S 30(f)$ imposes on greater than ten percent shareholders the reporting requirements and trading restrictions of Securities Exchange Act $\$ 16,15$ U.S.C. \& 78p (1970). Id. \$ 80a-29(f); SEC Investment Company Act rule 30f-1, 17 C.F.R. $\$ 270.30 \mathrm{f}-1$ (1977).

221. 12 C.F.R. $\$ 9.18($ b)(9)(ii) (1977).

222. Id. $\$ 9.18(\mathrm{~b})(9)(i i i)$. For the provisions dealing with admissions and withdrawals, see id. $\$ 9.18(\mathrm{~b})(4)$. If a common trust fund would have less than forty percent of its assets in cash and readily marketable assets after requested proposed admissions and withdrawals, then no admissions or withdrawals may be made except for ratable distributions to all participants. Id. $\S$ 9.18(b)(9)(iii).

223. Id. §§ 9.18(b)(10), (11).

224. Id. $\$ 9.18(\mathrm{c})(1)$.

225. Id. $\S \S 9.18(\mathrm{c})(2),(3),(4)$ (single real estate loans, variable amount note of a prime creditor, short-term cash fund, court ordered investments).

226. Id. $\S 9.18(\mathrm{c})(5)$. It will be recalled that the Citibank commingled managing agency fund did not in fact comply with Regulation 9 but operated pursuant to a letter issued by the Comptroller under this catch-all provision. See note 102 supra.

227. 15 U.S.C. \& 77k (1970). See Escott v. BarChris Const. Co., 283 F.Supp. 643 (S.D.N.Y. 1968); JenNings \& MARSH 1018-28; 3 Loss 1721-42; 6 Id. 3842-56 (Supp. 1969). See generally A.B.A. National Institute, supra note 118; Folk, supra note 118. Paragraph (e) of section 11 limits recovery of damages to the amount paid for the security.

228. 15 U.S.C. $\$ 771(1)$ (1970). See Jennings \& MARSh 1031-32; 3 Loss 1692-1712; 6 id. 3827-34 (Supp. 1969). Damages under section 12(1) are limited to the purchase price of the security.

229. 15 U.S.C. $\$ 771(2)$ (1970). See JeNnINGS \& MARSh 1036-38; 3 Loss 1692-1712; 6 id. 3827-34 (Supp. 1969). Damages under section 12(2) are limited to the amount paid for the security. 
there has been a false or misleading fact in a registration statement, where a security has been sold in violation of section 5 , or where there has been a false or misleading fact in a prospectus or oral communication. Similarly, section 36(b) of the Investment Company $\mathrm{Act}^{230}$ provides a right of action for an investment company shareholder regarding a breach of fiduciary duty by a person associated with the investment company. Additionally, courts have implied private rights of action to enforce the general antifraud provisions in section 17(a) of the Securities Act of $1933,{ }^{231}$ SEC Securities Exchange Act rules 10b-5232 and 14a-9,233 section 14(e) of the Securities Exchange Act $^{234}$ and section 206 of the Investment Advisers Act. ${ }^{235}$ Cus-

230. 15 U.S.C. \$ 80a-35(b) (1970). See Freedman \& Rosenblat, supra note 148; North 72628. Section 36(b)(1) states that a plaintiff shall have the burden of proving a breach of fiduciary duty, and that it is not necessary to allege or prove personal misconduct. Section 36(b)(2) permits a court to give such consideration as may be appropriate to the fact that an investment company's board of directors has approved the payments at issue. Section $36(b)(3)$ limits recovery of damages to the period ending one year prior to commencement of the action and precludes recovery of actual damages in excess of the amount of compensation received by the associated person. Section 36(b)(4) excludes from direct attack under section 36 payments that are subject to section 17 or are sales loads paid in share-for-share or share-for-assets acquisitions by a registered investment company. Cf. Boyko v. Reserve Fund, Inc., [1975-1976 Transfer Binder] FED. SEC. L. REP. (CCH) ๆ 95,304 (S.D.N.Y. 1975) (demand for board action prior to filing a derivative action presumed to be futile where action is to be brought under section 36(b) and at least one interested director sits on the fund's board). But see Lasker v. Burks, [Current] FED. SEC. L. REP. (CCH) I 96,282 (2d Cir. 1978) (disinterested directors cannot terminate a nonfrivolous lawsuit against the fund's investment adviser and interested directors).

231. 15 U.S.C. \$ 77q(a) (1970). See, e.g., Crowell v. Pittsburgh \& Lake Erie R.R. Co., 373 F.Supp. 1303 (E.D. Pa. 1974). But see Globus v. Law Res. Serv. Inc., 418 F.2d 1276 (2d Cir. 1969), cert. denied, 397 U.S. 913 (1970); SEC v. Texas Guif Sulphur Co., 401 F.2d 833, 867 (2d Cir.) (Friendly, J., concurring), cert. denied, 394 U.S. 976 (1968); 3 Loss 1785. In a major opinion limiting the scope of SEC Securities Exchange Act rule 10b-5 Mr. Justice Rehnquist stated ominously in a footnote that the Supreme Court "expressed, of course, no opinion on whether $\$ 17$ (a) in light of the express civil remedies [in section 12] of the 1933 Act gives rise to an implied cause of action." Blue Chip Stamps v. Manor Drug Stores, 421 U.S. 723, 737 n.6 (1975).

232. 17 C.F.R. $\S 240.10$ b-5 (1977). Despite a torrent of rule $10 \mathrm{~b}-5$ cases in the federal district courts and circuit courts of appeal, the Supreme Court did not address the implied private right of action question until 1971, and then dismissed the issue in a brief sentence in a footnote. Superintendent of Ins. of New York v. Bankers Life \& Casualty Co., 404 U.S. 6, 13 n.9 (1971). See note 125 supra.

233. 17 C.F.R. § 240.14a-9 (1977). See Mills v. Electric Auto-Lite Co., 396 U.S. 375 (1970); J.I. Case Co. v. Borak, 377 U.S. 426 (1964). See also JENNINGS \& MARSH 1351-60; 2 Loss 932 72; 5 id. $2879-949$ (Supp. 1969).

234. 15 U.S.C. $\$ 78 n(e)$ (1970). See Piper v. Chris-Craft Indus., Inc., 430 U.S. 1 (1977); Electronic Specialty Co. v. International Controls Corp., 409 F.2d 937 (2d Cir. 1969).

235. 15 U.S.C. $\$ 80 b-6$ (1970). See Wilson v. First Houston Inv. Corp., (5th Cir. Feb. 2, 1978), discussed in 440 SEC. REG. \& L. REP. (BNA) A-1 to -2 (1978); Abrahamson v. Fleschner, [1976-1977 Transfer Binder] FED. SEC. L. REP. (CCH) I 95,889 (S.D.N.Y. 1977); Sullivan v. Chase Investment Services of Boston, Inc., 434 F. Supp. 171 (N.D. Cal. 1977); Jones v. Equitable Life Assurance Soc'y of the United States, 409 F.Supp. 370 (S.D.N.Y. 1975); Bolger v. Laventhal, Krekstein, Horwath \& Horwath, 381 F.Supp. 260 (S.D.N.Y. 1974), [1974-1975 
tomers of broker-dealers and shareholders of investment companies have been able to sue privately where there have been violations of the relevant statutes or SEC rules, ${ }^{236}$ but have had mixed success in attempting privately to enforce rules of stock exchanges ${ }^{237}$ or self-regulatory organizations. ${ }^{238}$ And, persons who were neither customers nor shareholders but were otherwise affected by allegedly unlawful activities of broker-dealers or investment companies have had very little success in attempting privately to enforce compliance with particular statutory provisions. ${ }^{239}$

Participants in bank services which involve a trust relationship will, of course, be entitled to a judicially-reviewable accounting. ${ }^{240}$ Aggrieved par-

Transfer Binder] FED. SEC. L. REP. (CCH) ๆ 94,739 (S.D.N.Y. 1974) (rehearing). But see Greenspan v. Del Toro, [1975-1976 Transfer Binder] FED. SEC. L. REP. (CCH) ๆ 95,488 (S.D. Fla. 1974); Gammage v. Roberts, Scott \& Co., [1974-1975 Transfer Binder] FED. SEC. L. REP. (CCH) \94,761 (S.D. Calif. 1974). See also Note, Private Right of Action for Damages Allowed Against an Investment Adviser and His Accountant, 43 FordHAM L. REv. 493 (1974); Note, Private Causes of Action Under Section 206 of the Investment Advisers Act, 74 MICH. L. REv. 308 (1975).

236. The specific statutory provisions, rules, and interpreting cases are too numerous to cite here individually. See notes 133-48 supra; JENNINGS \& MARSH 787-868 (regulation of brokerdealers), 1389-1405 (margin rules), 1467-1560 (regulation of investment companies). See also Hibbard, Private Suits Against Broker-Dealers: A Proposal to Limit the Availability of Rescissory Relief for Misrepresentations Implied By the Shingle Theory, 13 HARV. J. LegIs. 1 (1975).

237. See, e.g., Utah State Univ. of Agriculture \& Applied Science v. Bear Stearns \& Co., 599 F.2d 164 (10th Cir. 1977) (no private right of action to enforce stock exchange or NASD rules); Buttrey v. Merrill Lynch, Pierce, Fenner \& Smith, Inc., 410 F.2d 135 (7th Cir.), cert. denied, 396 U.S. 838 (1969); Colonial Realty Corp. v. Bache \& Co., 358 F.2d 178 (2d Cir.), cert. denied, 385 U.S. 817 (1966). See also Allen, Liability Under the Securities Exchange Act for Violations of Stock Exchange Rules, 25 Bus. LAw. 1493 (1970); Fleming, Implied Remedies for Violations of Exchange Listing Agreements, 64 GEo. L.J. 925 (1976); Lowenfels, Implied Liabilities Based Upon Stock Exchange Rules, 66 CoLUM. L. REv. 12 (1966); Wolfson \& Russo, Stock Exchange Meniber: Firm Liability for Violation of Stock Exchange Rules, 58 CALIF. L. REV. 1120 (1970).

238. See, e,g., Utah State Univ. of Agriculture \& Applied Science v. Bear, Stearns \& Co., 599 F.2d 164 (10th Cir. 1977); Lange v. H. Hentz \& Co., 418 F.Supp. 1376 (N.D. Texas 1976); Plunkett v. Dominick \& Dominick Inc., [Current] FED. SEC. L. REP. (CCH) I 95,728 (D. Conn. 1976). See Lowenfels, Private Enforcement in the Over-the-Counter Securities Markets: Implied Liabilities Based on NASD Rules, 51 CORNELL L.Q. 633 (1966).

239. See SEC v. General Time Corp., 407 F.2d 65 (2d Cir. 1968), cert. denied, 393 U.S. 1026 (1969) (target company lacks standing to complain of acquisition of its stock absent compliance with prior approval procedure of SEC Investment Company Act rule 17d-1); Nachman Corp. v. Halfred, Inc., [1973-1974 Transfer Binder] FED. SEC. L. REP. (CCH) I 94,455 (N.D. III. 1973) (target company lacks standing to seek relief for alleged violation of the registration and regulatory provisions of the Investment Company Act).

240. G. BOGERT, supra note 19, at \$\$ 861-871 (remedies of beneficiary and trustee), $961-980$ (accounting and compensation); 2 A. SCOTT, LAW OF TRUSTS $\$ 172$ (duty to keep and render accounts), 197-226 (remedies of the beneficiary and liabilities of the trustee) (3d ed. 1967, Supp. 1977). Even where there is no trust relationship as such, an individual participant in a bank service could always seek judicial review of particular actions, bottomed on any type of alleged violations of the federal antitrust, banking or securities laws. E.g., O'Donnell vं. Continental Ill. Nat'l Bank \& Trust Co., [1972-1973 Transfer Binder] FED. SEC. L. REP. (CCH) ๆ 93,920 (N.D. IIl. 1973) (summary of complaint filed Mar. 27, 1973); Laing, Fiduciary Giants: Huge Sums 
ticipants in bank services not involving a full-blown trust relationship may, however, have serious, if not insuperable, difficulties in maintaining a class action against a bank for claims bottomed on activities affecting many trust accounts which are alleged to be violations of the federal securities or antitrust laws. ${ }^{241}$ Finally, a participant in a commingled managing agency fund operated by a Chicago bank who brought suit after the Camp case alleging violations of the Glass-Steagall Act and the making of unsuitable investments was found to have no standing to bring such a suit. ${ }^{242}$ Thus, aggrieved participants in bank services appear to have significantly fewer opportunities for private rights of action to protest effectively allegedly unlawful activities where the particular investment management service is not also registered under or subject to some or all of the federal securities laws. ${ }^{243}$

Managed by Bank Trust Units Stir Up Controversy, Wall St. J., Jan. 7, 1975, at 1, col. 6; Continental Illinois Bank Sued Over Management of UAL Pension Fund, Wall St. J., Mar. 29, 1973, at 12, col. 1. See also Penn, U.S. Steel Pension Fund Sues Citibank for not Warning of Toppers' Condition, Wall St. J., May 15, 1974, at 17, col. 1; Bankers Trust Is Sued Over Its Management of Union Pension Fund, Wall St. J., Apr. 25, 1972, at 10, col. 2.

241. E.g., Schaffner v. Chemical Bank, 339 F.Supp. 329 (S.D.N.Y. 1972). The complaint appears in 81 SEC. REG. \& L. REP. (BNA) D-1 (Dec. 16, 1970). The plaintiff in this case alleged that the bank was using trust account brokerage commissions to attract demand deposits from Wall Street broker-dealers, thereby wrongfully misusing the brokerage commissions which could have been used to obtain portfolio advice, to get better execution of individual transactions especially in the Third Market and to reduce portfolio turnover. These activities purportedly created a tying arrangement which violated the Sherman Act, the antifraud provisions of the Securities Exchange Act and the prohibition against paying interest on demand deposits in the Federal Reserve Act. Plaintiff, however, had requested that the brokerage commissions from her account be directed to a particular broker for over thirty years, and thus had not actually been involved in the alleged reciprocal business. Judge Pollack found the variety of trust instruments and layers of vested and contingent beneficiaries which would be encompassed by a class action to be so complex and bewildering that he held the class action unavailable and suggested her best remedy was the state law action for an accounting. Plaintiff then settled the suit. Trust Beneficiaries Drop Two New York Bank Suits, Wall St. J., Apr. 9, 1973, at 6, col. 2.

242. Russell v. Continental Ill. Nat'l Bank \& Trust Co., 479 F.2d 131 (7th Cir.), cert. denied, 414 U.S. 1040 (1973). There being no express statutory provisions permitting private rights of action under the Glass-Steagall Act, the court of appeals based its decision as to who had standing upon the legislative history of the Glass-Steagall Act, and determined that, while bank depositors might have standing, participants in bank-sponsored investment management services were not persons Congress intended to be protected by the Glass-Steagall Act. It seems quite clear, nevertheless, that the Seventh Circuit Court of Appeals has simply misread the legislative intent of Congress in 1933 since at least one major purpose of the Glass-Steagall Act was to remove the deleterious effect that abusive conflicts of interest had had upon the integrity of bank-sponsored investment management services. Thus, participants in those services should more readily than bank depositors or shareholders have been granted standing to protest activities which are allegedly illegal under the Glass-Steagall Act.

243. See O'Brien v. Continental Ill. Nat'l Bank \& Trust Co., 431 F. Supp. 292 (N.D. Ill. 1977) (trust beneficiary's claim that trustee fradulently retained securities fails to state claim under rule $10 \mathrm{~b}-5$ because beneficiary was not purchaser or seller; trustee is not required to disclose to beneficiary material nonpublic information on the commercial side where trustee 


\section{SUGGESTED LEGISLATIVE AND STATUTORY INTERPRETIVE RESPONSES}

The foregoing comparison of the regulatory schemes under the federal securities and banking laws suggests that a number of legislative changes and statutory interpretations could be made which would provide a better investor protection environment for participants in bank-sponsored investment management services, and thereby harmonize more completely the total regulatory framework imposed by the federal securities and banking laws on such services. The cumulative regulatory structure provided under each system is largely a function of, and has evolved almost exclusively with, its own peculiar history, even though modern regulation should more properly be shaped by concerns for appropriate controls over the particular service being provided to achieve essential investor protections than by the fortuitousness of which type of financial institution first developed the service.

Moreover, it seems clear that, relatively speaking, persons in the securities industry offering collective investment management services are subject to quite detailed regulation but limited direct supervision, while the banking industry, on the other hand, is subject to enormous amounts of direct supervision but very limited external guidance through rules or regulation. While the former system might be criticized by some for "overregulation" of business decisions, the latter system has a more significant disadvantage. Because there is little role for private attorneys general, effective regulation is highly dependent upon on-site visitation and an expensive examining and supervisory staff. When coupled with relatively few regulations, that type of regulatory framework, it seems, leaves the unnecessarily lingering suspicion that bank regulators (or banks) cannot or will not tolerate an outside investigation, that only bank regulators (or banks) are competent to judge appropriate regulatory controls, and that the regulatory process is best carried out with maximum secrecy and minimum public scrutiny. ${ }^{244}$ The following recommendations attempt, then, to raise to the highest minimum standards certain investor protections for persons

has investment discretion; failure to disclose is not "in connection with" the purchase or sale of a security and is not material to any investment decision by beneficiary; purchases by bank to support commercial side merely allege breach of fiduciary duty, not fraud); Local 734 Bakery Drivers Pension Fund Trust v. Continental Ill. Nat'l Bank \& Trust Co., [1973-1974 Transfer Binder] FED. SEC. L. REP. (CCH) I 94,565 (N.D. Ill. 1974) (beneficiaries of pension trust agreement have standing under SEC rule $10 \mathrm{~b}-5$ to bring an action alleging nondisclosure of material facts and concealed conflicts of interest which resulted in substantial losses in securities transactions).

244. See, e.g., Lehner, In Lance's Wake: More Disclosure of Bank Affairs, Wall S. J., Oct. 31,1977 , at 16, col. 6 ("Historically, bank regulation has rested on the 'paternalistic old notion' that 'bankers and regulators can solve problems better if bank stockholders and depositors are ignorant,'" (quoting Georgetown University Law Center Professor Roy A. Schotland)). 
considering different financial institutions offering competitive investment management services, while hopefully imposing no restraints on particular competitors which would lead to unequal competition (other than differences in actual performance) based on the mere fact of being subject for historical reasons to different regulatory systems.

\section{A. Glass-Steagall Act.}

Because of the Supreme Court decision in Camp, difficult interpretive questions can be raised about the legality under the Glass-Steagall Act of certain bank-sponsored investment management services, such as common trust funds, employee benefit plan collective investment trust funds and mini-accounts. ${ }^{245}$ These services are plainly valuable to investors and, through strong competition with other services, tend to improve the economic efficiency of the institutional investor marketplace. They should be constrained, therefore, only where actual or potential abuses threaten the integrity of the particular service or of banks as lending institutions. It seems very likely that, at least with respect to common trust funds and employee benefit plan collective investment trust funds, Congress probably would have excepted the activity from the Glass-Steagall Act in 1933 if it had considered the issue, even though the bank's role in these activities would fall within the meaning customarily ascribed to the term "underwriter." There do not appear to be any abuses regarding common trust funds or employee benefit collective investment trust funds which are not present in the operation of traditional individual fiduciary activities by bank trust departments, where Congress clearly did not intend to impose restrictions and was prepared to tolerate the potential for abuses. Thus, legislative amendments should be made to the Glass-Steagall Act which explicitly exclude those activities from the investment banking prohibitions. ${ }^{246}$

The offering of mini-accounts not involving individualized treatment is, on the other hand, not a traditional fiduciary activity and does in many

245. See text accompanying notes 76-78 supra. See also Note, Bank-Sponsored Investment Services: Statutory Proscriptions, Jurisdictional Conflicts, and a Legislative Proposal, $27 \mathrm{U}$. FLA. L. REv. 776 (1975); Note, The Legal Status of a National Bank's Automatic Stock Investment Service Under Sections 16 \& 21 of the Glass-Steagall Act of 1933, 27 VAND. L. REv. 1217 (1974); Note, The Legality of Bank-Sponsored Investment Services, 84 YALE L.J. 1477 (1975). For discussions of the Glass-Steagall Act prohibitions on bank underwriting of municipal securities, see Mehle, Bank Underwriting of Municipal Revenue Bonds: Preserving Free and Fair Competition, 26 Syracuse L. Rev. 1117 (1975); Rogowski, Commercial Banks and Municipal Revenue Bonds, 95 BANKING L.J. 155 (1978).

246. Although others may differ as to the appropriate provision to be amended, the section granting and limiting the investment powers of national banks, 12 U.S.C. $\$ 24$ seventh (1970), would appear to be the best provision for legislation since any changes there made would without further amendment naturally affect the powers of state-chartered banks by removing pro tanto the prohibitions thereon in 12 U.S.C. $\$ 378(a)(1)(1970)$. 
respects resemble the commingled managing agency account arrangements struck down by the Supreme Court in the Camp case because of the existence of the potential abuses addressed by the Glass-Steagall Act. Indeed, one strong characteristic joining together the mini-account and commingled managing agency account services (as distinguished from the other traditional collective investment trust funds and fiduciary activities generally) is aggressive use of advertising, structured to take greatest advantage of the bank's general reputation as an investment adviser. ${ }^{247}$ In all other respects, however, it would seem that the potential abuses arising from the offering of commingled managing agency accounts are equally applicable to offering of traditional fiduciary services, such as individual trust investment management. Because such advertising was considered an abuse by the draftsmen of the Glass-Steagall Act, and was a significant factor supporting the Supreme Court's Camp decision, it would appear then that the offering of mini-accounts not involving individualized treatment by banks should receive legislative protection and sanction under the Glass-Steagall Act only if the service when offered is subject to the same advertising constraints traditionally imposed by federal bank regulatory agencies on common trust funds and collective investment trust funds. Because that degree of advertising restriction might possibly be more exacting than restraints imposed under the Securities Act of 1933 on investment compamies or investment advisers, the legislation should permit the appropriate federal bank regulatory agency to promulgate rules which would mirror substantially any evolving SEC disclosure policy relaxing the advertising restrictions on investment companies and tightening disclosure and advertising restraints on investment advisers.

With regard to structure, a functional equivalent to the role of independent directors required under the Investment Company Act is conspicuously absent in the offering of bank-sponsored investment management services, even though the potential conflicts of interest between a bank as investment adviser and collective investment trust funds as entities would not appear to be significantly different in variety or amplitude from those of the investment company adviser. It would be difficult to provide parallel treatment by statute, since it would be functionally impossible to have trust beneficiaries vote for directors even if there were a plausible practical method for interposing a new set of directors between those of the bank and the particular service. However, functional equivalence could otherwise be approximated if federal bank regulations required a panel of the bank's own independent directors to assume special responsibilities similar to those imposed on investment company independent directors respecting the investment management fee and conflict of interest transactions. ${ }^{248}$ Finally,

247. See text accompanying notes $39 \& 102$ supra.

248. See text accompanying notes $147-48,155-58$ supra. 
despite the very real problems of maintaining a class action where the putative plaintiffs are beneficiaries in different degrees under trust agreements with varying provisions, the Glass-Steagall Act should be amended to provide for private rights of action in the nature of a shareholder's derivative suit for participants in bank-sponsored investment management services where the allegedly illegal activity affects a wide range of participants or where it runs to the underlying legality of the offering of a particular service.

\section{B. Federal Securities Laws and the ALI Federal Securities Code Project.}

The American Law Institute has published a formal tentative draft of the ALI Code provisions dealing with the regulation of investment companies. This affords a highly propitious opportunity for cleaning up prior unintentional drafting errors and omissions, ${ }^{249}$ and for harmonizing the

249. Specific drafting errors and omissions have already been highlighted in notes $42,95 \&$ 96 supra and will not be reiterated here. However, it might be noted that sections 301(e) and (f) of the ALI Code in their present form differ even from their present defective statutory counterparts in section 3(a)(2) of the Securities Act of 1933. ALI FED. SEc. CoDE $\S \S 301(e)$ and (f) (Tent. Drafts Nos. 1-3 revised, I974); ALI FED. SEC. Code $§ 301(e)$ (Tent. Draft No. 6, 1977).

First, the phrase "or in a similar personalized fiduciary capacity" has been added to the end of the exemption for common trust funds in section 301(e) of both Tentative Drafts Nos. 13 and No. 6, thereby possibly unnecessarily opening up again the eight-year long controversy over commingled managing agency accounts begun in 1963. The Reporter's Note (1) to section 301(e) (Tent. Drafts Nos. 1-3, 1974) states, despite citing on the preceding page certain of the strong language in the legislative history to the contrary, that the additional phrase is necessary to include the occasions when a bank would be acting "as a 'conservator' or 'committee' or as 'custodian' under the Uniform Gifts to Minors Act." Id. 46-47. The Reporter's Note to section 301(e) Tentative Draft No. 6 states that the additional phrase is not intended to include commingled managing agency accounts, and is to be interpreted by the SEC "without regard to any rulings of the bank regulators." ALI FED. SEC. CoDE (Tent. Draft No. 6, 1977) § 301(e), comment (1), at 63. With all respect, the proposed interpretation appears already one which could be covered by the present statutory language. In any event, the SEC could always interpret the present statutory phrases to include the additional fiduciary roles that concern the Reporter if the problem were severe and important enough to banks to warrant submission of a no-action request or of an exemptive rule proposal. E.g., Letter from SEC Division of Corporate Finance to Bankers Trust New York Corp. (Mar. 3, 1977), [1977-1978 Transfcr Binder] FED. SEC. L. REP. (CCH) I 81,229 (no-action given under Securities Act $\S 3($ a)(2) for investment of guardianships in common-trust funds). Also, the IRS ruled precisely to the contrary in interpreting Internal Revenue Code $\S 584(\mathrm{a})$, Rev. Rul. 76-326, 1976-2 C.B. 182, although recent legislative changes to section 584(a)(1) would now accomplish this result. See I.R.C. $\$ 584(\mathrm{a})$. Thus, the additional phrase seems at best superfluous and at worst mischievous, even with a Reporter's Note to explicate the ALI's legislative intent. Moreover, the transcription of the exemption for employee benefit plan collective investment trust funds is seriously deficient in that it repeats the "single or" drafting error discussed in note 96 supra, and deletes the "solely" condition discussed in note 98 supra. ALI FED. SEC. CODE (Tent. Drafts Nos. 1-3, 1974) § 301(f). However, the Reporter has redrafted Investment Company Act $\S 3(c)(11)$, ALI FED. SEC. CODE $\S 250(b)(10)$ (Tent. Draft No. 6, 1977), and apparently intends to redraft section $301(f)$ to cure the "single or" drafting error discussed in note 96, supra. Id. comment (12) at 37-38. 
regulation of bank-sponsored investment management services with that otherwise imposed for the protection of investors in investment companies.

\section{Securities Act of 1933.}

Mini-accounts not involving individualized treatment, registered investment companies and Keogh employee benefit plan trusts are already fully subject to the disclosure and prospectus delivery requirements of the Securities Act, while common trust funds and corporate employee benefit plan trusts which involve the offering of a security are subject only to the negative disclosure requirements of the several general antifraud provisions. The policy reason advanced in 1963 for treating those two services as if they were exempt by express statutory provision was that the historic method employed by banks in offering and selling interests in these services was substantially akin to a nonpublic offering. ${ }^{250}$ The Commission's no-action position subsequently was codified in 1970. However, since 1963 there have been dramatic developments affecting interpretation of the nonpublic offering exemption. ${ }^{251}$ It is highly questionable whether a bank requiring use of pre-printed trust forms, permitting little or no bargaining over investment management fees and disclosing relatively little about the operations, management and financial condition of the bank as a financial institution could satisfy current standards. Moreover, the current disclosure requirements of the federal banking laws lack the degree of rigor and detail to be considered an adequate substitute for the Securities Act provisions. Accordingly, it would appear appropriate at this time seriously to consider removing the exemptions in section $3(\mathrm{a})(2)$ for common trust funds and corporate employee benefit trust funds. It could be expected (and statutorily required) that the Commission would devise appropriately brief short-form registra-

Finally, it should be noted that the Reporter has deleted any statutory reference to individual or group IRAs and other unusual tax-exempt funds, in reliance on the proposed provisions in section 302 of the ALI Code which would permit the Commission to exempt the offer and sale of such securities from the registration and disclosure requirements of the Code "to the extent consistent with the purposes of the provision from which it is granting exemption." ALI FED. SEC. CODE (Tent. Draft Nos. 1-3, 1974) §§ 302(a), (c); id. note on balance of $\S$ 301 , at $43-47$.

250. See text accompanying notes 25 \& 39 supra.

251. E.g., Woolf v. S.D. Cohn \& Co., [1975-1976 Transfer Binder] FED. SEC. L. REP. (CCH) If 95,223 (5th Cir. 1975) (insubstantial disclosure made with no proof as to sophistication of offerees; cause of action stated under SEC Securities Exchange Act rule 10b-5); SEC v. Continental Tobacco Co., 463 F.2d 137 (5th Cir. 1972) (offeree must have a privileged relationship with issuer which gives him access to registration-type information or any additional information he might require); SEC Securities Act Release No. 5487 (Apr. 23, 1974), 1 FED. SEC. L. REP. (CCH) I 2710 (adoption of SEC Securities Act rule 146, 17 C.F.R. $\$ 230.146$ (1977)). See generally Alberg \& Lybecker, New SEC Rules 146 and 147: The NonPublic and Intrastate Offering Exemptions from Registration for the Sale of Securities, 74 COLUM. L. REV. 622 (1974). 
tion statements and relaxed post-effective amendment requirements in light of the continuous nature of these two services.

2. Securities Exchange Act.

a. Continuous Disclosure Provisions. The reporting requirements of section 13 of the Securities Exchange Act should similarly be amended to eliminate the exemptions for common trust funds and corporate employee benefit trust funds.

b. Broker-Dealer Regulatory Provisions. Perhaps the biggest difference between the federal securities and banking laws is the absence under the latter of any professional qualification requirements, even though there are distinct functional similarities between a broker-dealer and a trust officer. ${ }^{252}$ Nor would it appear that federal bank regulatory agencies, with their heavy emphasis on examinations and financial solvency, would be seriously interested in developing specified standards of training for trust department personnel. The definitions in the Securities Exchange Act of "broker" and "dealer" should thus be amended in the same manner as was employed in 1975 respecting bank municipal bond trading departments ${ }^{253}$ to subject the appropriate bank employees to the substantial equivalent of the minimum professional qualification requirements established by the SEC for brokerdealers. It almost goes without saying that the financial responsibility provisions of the Securities Exchange Act would surely be largely superfluous respecting bank services, considering the substantial efforts expended by federal bank regulatory agencies toward achieving financial solvency of the bank as a whole unit.

\section{Investment Company Act.}

Assuming that the suggestions made above respecting use of independent directors and private rights of action regarding bank-sponsored investment management services were adopted, the remaining portions of the respective regulatory schemes under the Investment Company Act and the federal banking laws appear to be roughly comparable in providing essential investor protections. ${ }^{254}$

252. It will be recalled that the Investment Company Amendments Act of 1970 contained a provision addressed to this deficiency until virtually the very last moment before adoption. See text accompanying notes 55-56 supra; note 255 infra.

253. 15 U.S.C. $\$ 78 \mathrm{c}(30)$ (Supp. V 1975) ("'t]he term 'municipal securities dealer' means any person (including a separately identifiable department or division of a bank)"). Thus, the definitions of broker and dealer might be amended to include a separately identifiable department or division of a national or state-chartered bank or trust company engaged in the business of exercising fiduciary powers similar to those permitted to national banks under the authority of the Comptroller of the Currency, and so forth.

254. Prior to adoption of ERISA, it could have been argued that the exemption for employee benefit plan trusts from the Investment Company Act was unjustified logically because the 
4. Investment Advisers Act.

There are few regulatory provisions in the Investment Advisers Act, but imposition of all, in the manner suggested above for amending the definitions of broker and dealer, would seem desirable. A bank trust department would then be subject to restrictions on performance fees, scalping and advertising, and to general antifraud provisions which do not depend on the purchase or sale of a security with respect to collective investment trust funds and all types of individual advisory accounts. ${ }^{255}$

\section{Allocation of Regulatory Responsibility and Oversight Function.}

The compromise arrangement reached in 1975 regarding regulation of transfer agencies would appear in many respects to be appropriate here, too, thereby generally giving the SEC the overall authority to promulgate rules and regulations while the appropriate federal bank regulatory agency would have examination and enforcement responsibility regarding bank services. $^{256}$ The only exception necessary to this proposed general allocation of

relevant regulation provided by the Internal Revenue Code was designed largely to prevent discrimination between types of employees, not to protect all employees in their status as investors. The extraordinary complexity of ERISA makes most difficuit a thorough comparison of its provisions with those of the federal securities laws, although one is inclined impressionistically to believe that much if not all of the prior gap may have disappeared.

255. Were the proposed legislation amending the Investment Advisers Act to provide the statutory authority to impose professional qualification and responsibility requirements already adopted, there would be no logical reason, of course, to subject bank trust departments to the Securities Exchange Act also. See text accompanying notes 111 \& 139 supra. In that event, the prior suggestion in the text accompanying notes 252 \& 253 supra, as to the Securities Exchange Act, would be withdrawn. Under the ALI Code, with common registration and regulatory patterns for broker-dealers and investment advisers, the question of which Act should be amended largely disappears. ALI FED. SEC. CoDE, supra note 249, at $\$ \S 701-702,702(\mathrm{e})$.

256. 15 U.S.C. $\$ \$ 80 \mathrm{a}-15$ (registration), (d) (rulemaking and enforcement) (Supp. V 1975). See H.R. REP. No. 229, supra note 9, at 102-03 (1975). The SEC chose, instead, to recommend that the federal bank regulatory agencies be mandated to enact and enforce certain specific rules and regulations governing all aspects of bank brokerage activities. Final SEC Bank Study Report 48-49. Considering the primacy of the Commission's traditional experience in this area and the practical background suggesting difficulties in coordination of bank regulatory agency efforts, one must wonder what persuasive facts caused the SEC to abandon the seemingly successful 1975 compromise. Cf. Scott, The Dual Banking System: A Model of Competition in Regulation, 30 STAN. L. REv. 1 (1977) (study of the functions and structure of the dual banking system). Yet the SEC was apparently quite concerned about preserving a continuing role in regulation of bank brokerage activities and thus recommended: (1) the federal bank regulatory agencies be required to consult with the Commission and each other regarding regulations; (2) the federal bank regulatory agencies be required to adopt specific examination procedures designed to review all bank securities activities and train bank examiners in the requirements and practices of the federal securities laws; (3) the federal bank regulatory agencies be required to notify the Commission of any examinations conducted by them and furnish the Commission with copies of their reports and data; and (4) the federal bank regulatory agencies be required to advise the Commission of any actual or potential violations of the federal securities laws of which they become aware. Final SEC Bank Study Report 48-50. 
regulatory responsibilities ought to be that long-established Commission expertise in processing disclosure documents should prevail, so that all required disclosure documents for investment management services of all financial institutions receive equal treatment.

\section{CONCLUSION}

Based on the legal history of bank-sponsored investment management services and a comparison of the investor protections provided under the federal securities and banking laws, certain legislative changes and statutory interpretations have been suggested which might cure prior legislative errors and omissions and harmonize more carefully the regulatory frameworks of the federal securities and banking laws from the standpoint of essential investor protections. Some suggestions would appear to fall clearly within the scope and spirit of the ALI Federal Securities Code project; others are more controversial ${ }^{257}$ in that disclosure and regulatory constraints would be imposed where they do not now exist. It is believed, however, that adoption of these suggestions would provide an miproved regulatory environment more sensitive to necessary investor protections in the public interest. Therefore these suggestions should be given serious consideration by Professors Loss and Brudney, the ALI, the SEC and Congress as each weigh and balance the public policy implications of particular bank-sponsored investment management services.

257. Professors Loss and Brudney and the ALI must take into account political considerations which have been ignored here. The ALI Code is an extremely important endeavor and, if its central purposes were seriously jeopardized by consideration of certain suggestions, one could understand and appreciate a decision not to attempt extensive modifications in this area. 